$$
\begin{aligned}
& \text { hit } \\
& \text { Nus } 2 \text { I IyS } \\
& \text { OSTI }
\end{aligned}
$$

\title{
Lawrence Livermore National Laboratory Offsite Hazardous Waste Shipment Data Validation Report
}

Radioactive Waste

Technical Support Program

September 1995 


\title{
Lawrence Livermore National Laboratory Offsite Hazardous Waste Shipment Data Validation Report
}

\section{Published September 1995}

\author{
MSE, Inc. \\ 330 Shoup Ave, Ste. 201 \\ Idaho Falls, ID 83402 \\ Prepared for \\ Lockheed Idaho Technologies Company \\ Under Subcontract No. C93-170420 \\ and for the \\ U.S. Department of Energy
}

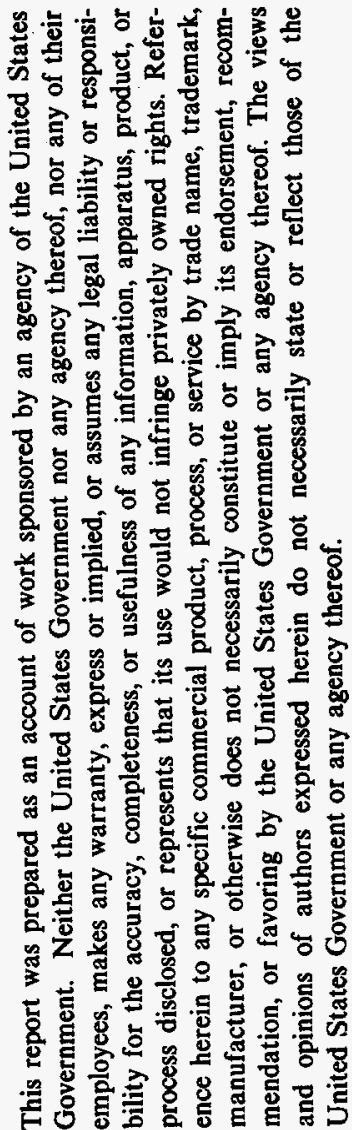

Assistant Secretary for Environmental Management

Under DOE Idaho Operations Office

Contract DE-AC07-94ID13223 


\section{DISCLAIMER}

Portions of this document may be illegible in electronic image products. Images are produced from the best available original document. 


\section{ABSTRACT}

The U.S. Department of Energy Headquarters (DOE-HQ) requested this report to verify that Lawrence Livermore National Laboratory (LLNL) properly categorized hazardous waste shipped offsite from 1984 to 1991 . LLNL categorized the waste shipments by the new guidelines provided by DOE-HQ on the definition of radioactive waste. For this validation, waste that has had no radioactivity added by DOE operations is nonradioactive. Waste to which DOE operations has added or concentrated any radioactivity is radioactive. This report documents findings from the review of available LLNL hazardous waste shipment information and summarizes the data validation strategy. The report discusses administrative and radiological control procedures in place at LLNL during the data validation period. It also describes sampling and analysis and surface survey procedures used in determining radionuclide concentrations for offsite release of hazardous waste shipments.

The evaluation team reviewed individual items on offsite hazardous waste shipments and classified them, using the DOE-HQ waste category definitions. LLNL relied primarily on generator knowledge to classify wastes. Very little radioanalytical information exists on hazardous wastes shipped from LLNL. Slightly greater than one-half of those hazardous waste items for which the documentation included radioanalytical data showed concentrations of radioactivity higher than the LLNL release criteria used from 1989 to 1991 . Based on this small amount of available radioanalytical data, very little ( less than one percent) of the hazardous waste generated at the LLNL main site can be shown to contain DOE added radioactivity. LLNL based the criteria on the limit of analytical sensitivity for gross alpha and gross beta measurements and the background levels of tritium. Findings in this report are based on information and documentation on the waste handling procedures in place before the start of the hazardous waste shipping moratorium in May 1991, not on current conditions at LLNL. 


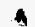




\section{CONTENTS}

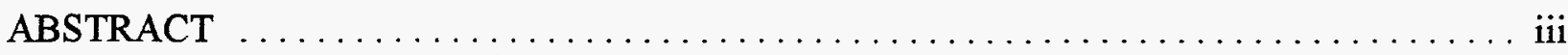

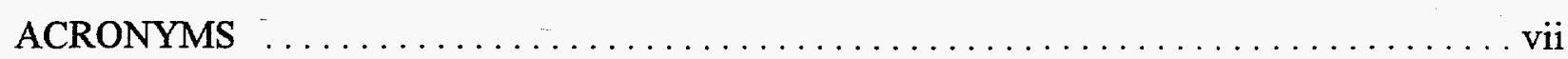

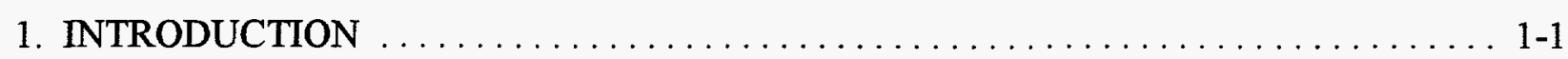

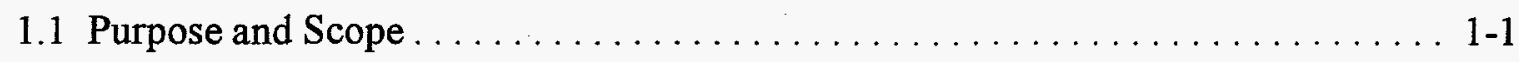

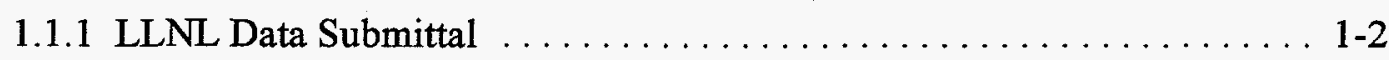

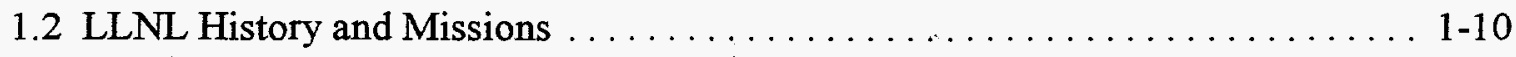

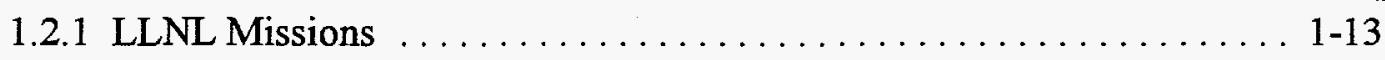

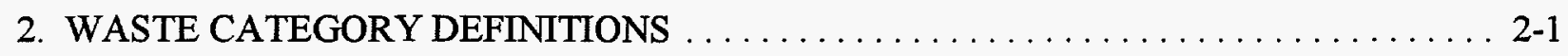

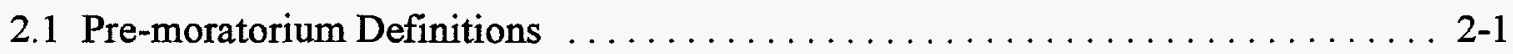

2.2 DOE-HQ Moratorium Definitions $\ldots \ldots \ldots \ldots \ldots \ldots \ldots \ldots \ldots \ldots \ldots \ldots \ldots \ldots \ldots \ldots, 2-1$

2.2.1 Radioactive Waste $\ldots \ldots \ldots \ldots \ldots \ldots \ldots \ldots \ldots \ldots \ldots \ldots \ldots \ldots \ldots \ldots, 2-1$

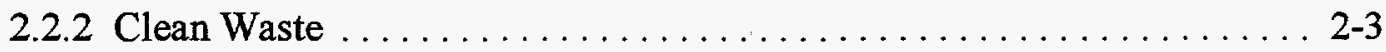

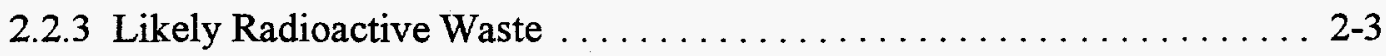

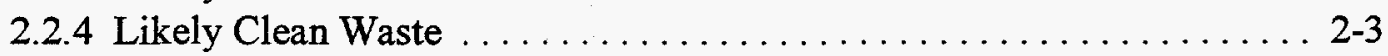

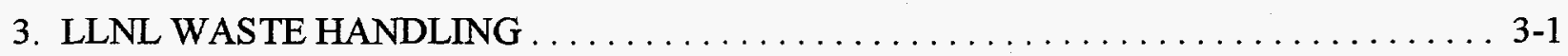

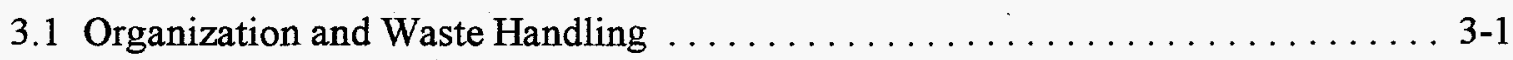

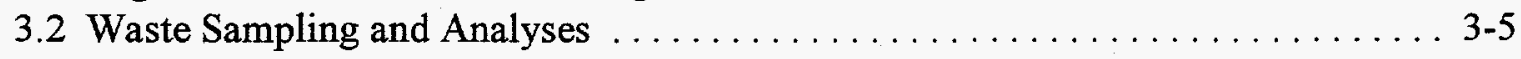

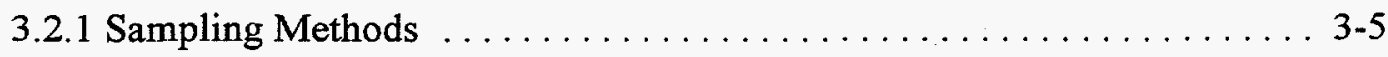

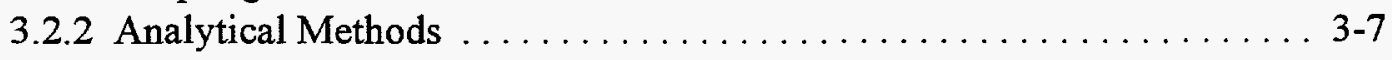

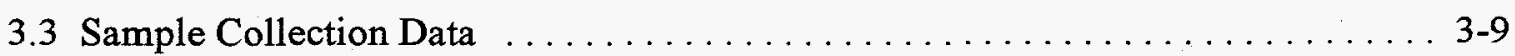

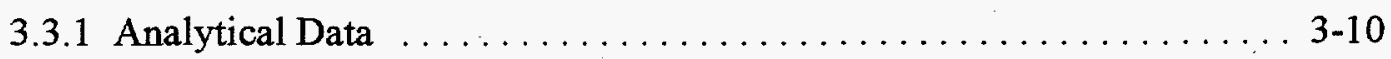

3.4 WAA Administration $\ldots \ldots \ldots \ldots \ldots \ldots \ldots \ldots \ldots \ldots \ldots \ldots \ldots \ldots \ldots \ldots \ldots \ldots \ldots, 12$

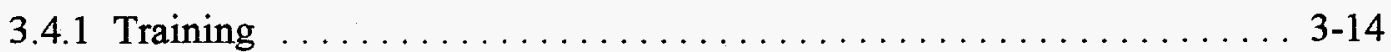

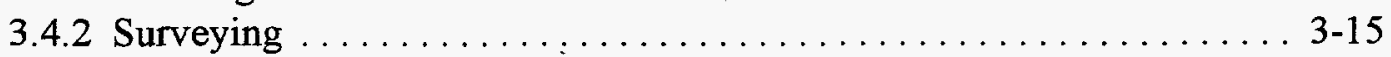

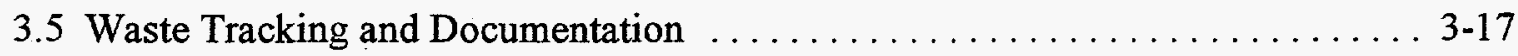

3.6 HWM Repackaging and Manifesting . . . . . . . . . . . . . . . . . . 3-18

3.7 Treatment, Storage, and Disposal Facilities ..................... 3-24 
3.7.1 Closed Treatment and Storage Facilities at LLNL . . . . . . . . . . 3-25

3.7.2 Currently Operating Treatment Facilities . . . . . . . . . . . 3-28

4. WASTE ITEM VALIDATION $\ldots \ldots \ldots \ldots \ldots \ldots \ldots \ldots \ldots \ldots \ldots \ldots \ldots \ldots \ldots$

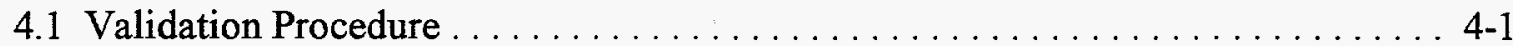

4.2 Validation Results . . . . . . . . . . . . . . . . . . . . . . .

4.2.1 Spot Check Results . . . . . . . . . . . . . . . . . 4-3

4.2.2 Random Manifest Results . . . . . . . . . . . . . . . . . 4-3

4.2.3 Biased H-Req Sample Results . . . . . . . . . . . . . . . 4-4

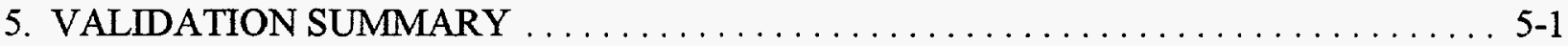

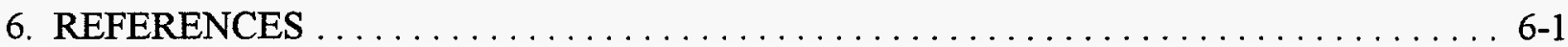

$\begin{array}{ll}\text { APPENDIX A } & \text { LLNL TSDF Flowcharts } \\ \text { APPENDIX B } & \text { Hazardous Waste Shipped Offsite, January 1990 to July 1991 } \\ \text { APPENDIX C } & \text { RMMA Table } \\ \text { APPENDIX D } & \text { H-Req Data Summary } \\ \text { APPENDIX E } & \text { H-Req Waste Designation }\end{array}$

FIGURES

1-1. LLNL site map. . . . . . . . . . . . . . . . . . . . . . . . . . . . . . 1-11

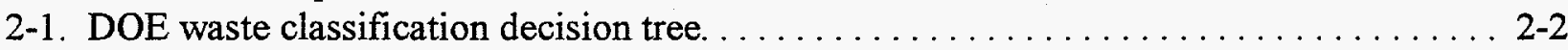

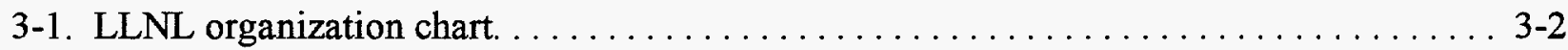

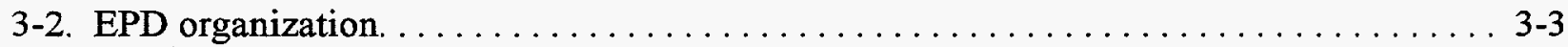

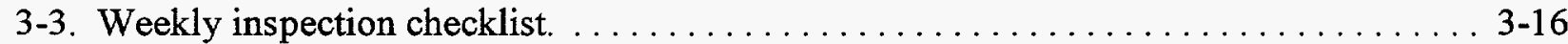

3-4. General LLNL Hazardous Waste Facility schematic. . . . . . . . . . . . . . . . . . . 3-19

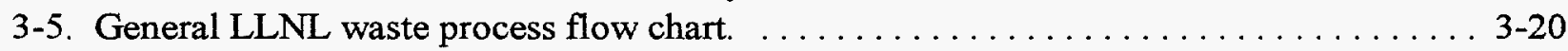

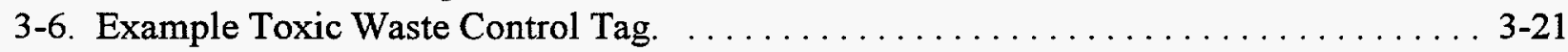

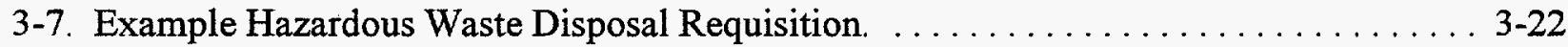

3-8. Hazardous Waste Information Database used in 1987. . . . . . . . . . . . . . 3-25

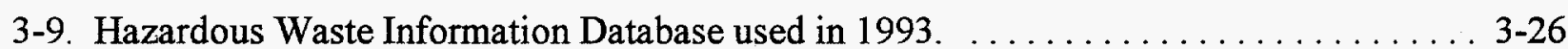

\section{TABLES}

1-1. Hazardous wastes shipped and incinerated from 1984 to 1991 (tons). . . . . . . . . . 1-4

1-2. Large waste streams at LLNL in 1990 and $1991 \ldots \ldots \ldots \ldots \ldots \ldots \ldots \ldots \ldots$

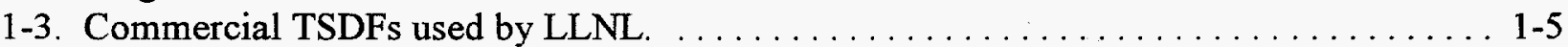

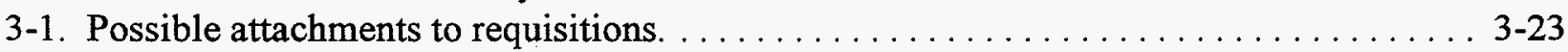

4-1. Randomly selected LLNL Uniform Hazardous Waste Manifests. . . . . . . . . . . . 4-2 


\section{ACRONYMS}

\begin{tabular}{|c|c|}
\hline $\mathrm{AEC}$ & Atomic Energy Commission \\
\hline ASTM & American Society for Testing and Materials \\
\hline AVLIS & Atomic Vapor Laser Isotope Separation \\
\hline $\mathrm{COC}$ & chain-of-custody \\
\hline DOE & U.S. Department of Energy \\
\hline DOE-HQ & U.S. Department of Energy Headquarters \\
\hline DOHS & Department of Health Services \\
\hline DOT & Department of Transportation \\
\hline EA & Environmental Analyst \\
\hline EAS & Environmental Analytical Services \\
\hline \multicolumn{2}{|c|}{ EM-30 DOE-HQ Environmental Restoration and Waste Management Office of Waste Operations } \\
\hline EM-331 & DOE-HQ Office of Waste Management Regulatory Compliance Division \\
\hline EPA & U.S. Environmental Protection Agency \\
\hline EPD & Environmental Protection Department \\
\hline ES\&H & Environmental Safety and Health \\
\hline FSP & Facility Safety Procedures \\
\hline H-Req & Hazardous Waste Disposal Requisitions \\
\hline $\mathrm{H} \& \mathrm{~S}$ & health and safety \\
\hline $\mathrm{HC}$ & Hazards Control Department \\
\hline $\mathrm{HP}$ & health physicist \\
\hline HWM & Hazardous Waste Management Division \\
\hline HWMDB & Hazardous Waste Management Database \\
\hline IH & industrial hygienist \\
\hline L-Req & Laboratory Waste Disposal Requisitions \\
\hline LLNL & Lawrence Livermore National Laboratory \\
\hline LLW & low-level waste \\
\hline LOS & level of sensitivity \\
\hline $\mathrm{M} \& \mathrm{O}$ & Management and Operations \\
\hline NAS & Naval Air Station \\
\hline $\mathrm{NRC}$ & Nuclear Regulatory Commission \\
\hline NTS & Nevada Test Site \\
\hline $\mathrm{QA} / \mathrm{QC}$ & quality assurance/quality control \\
\hline QAP & Quality Assurance Plan \\
\hline R-Req & Radioactive Waste Disposal Requisitions \\
\hline RCA & Radiological Control Area \\
\hline RCRA & Resource Conservation and Recovery Act \\
\hline RMMA & radioactive materials management area \\
\hline SOP & Standard Operating Procedure \\
\hline TSCA & Toxic Substance Control Act \\
\hline TSDF & transfer, storage, and disposal facility \\
\hline TWIMS & Toxic Waste Information Management System \\
\hline UC & University of Califormia \\
\hline USGS & U.S. Geological Survey \\
\hline WAA & Waste Accumulation Area \\
\hline WAC & Waste Acceptance Criteria \\
\hline
\end{tabular}




\section{Lawrence Livermore National Laboratory Offsite Hazardous Waste Shipment Data Validation Report}

\section{INTRODUCTION}

On May 17, 1991, the U.S. Department of Energy Headquarters (DOE-HQ) Environmental Restoration and Waste Management Office of Waste Operations (EM-30) directed field offices to stop shipping Resource Conservation and Recovery Act (RCRA) and Toxic Substance Control Act (TSCA) wastes that could be contaminated with radioactive material. According to DOE-HQ, waste could be radioactively contaminated if it has been used or stored in a Radiological Control Area (RCA) that could contain unconfined radioactive material or where exposure to beams of particles that can cause activation is possible. DOE-HQ decided to stop hazardous waste shipments because DOE sites were using differing, and sometimes inappropriate, criteria for determining if a waste was suitable for offsite release. The moratorium on offsite hazardous waste shipments remains in effect at each DOE site until DOE-HQ reviews and approves the criteria and methods for offsite release.

Lawrence Livermore National Laboratory (LLNL) received final DOE-HQ approval to recommence offsite shipment of RCRA and TSCA wastes generated after the site trained all generators in December 1991. In January 1992, LLNL resumed shipping wastes generated before generator training (Crawford 1994). As part of the moratorium on the offsite shipments of RCRA/TSCA wastes, DOE-HQ, in a memorandum (called the data request) (Duffy 1991), requested DOE sites to provide DOE-HQ detailed information about past RCRA/TSCA offsite waste shipments.

\subsection{Purpose and Scope}

This data validation supports the DOE Office of Waste Management Regulatory Compliance Division (EM-331) by collecting and documenting radioanalytical data to find out if DOE sites have correctly categorized their hazardous waste shipments. The goal of this validation is, therefore, to find out if LLNL shipped hazardous waste containing DOE-added radioactivity offsite before the start of the moratorium. It is not to learn the absolute quantity or destination of all wastes or radioactivity that may have contained $\mathrm{DOE}$-added radioactivity.

The LLNL offsite hazardous waste shipment data validation project examined shipment records for the requested period, 1984 through 1991, and decided if LLNL properly categorized items in offsite waste shipments, using the DOE-HQ waste category definitions from the data request. The evaluation team based this determination on whether DOE operations added radioactivity to the bulk or volume of the waste. A second criterion is whether the waste materials were shipped according to criteria for surface contamination in DOE Order 5400.5, "Radiation Protection of the Public and the Environment." (DOE 1993) The team conducted an onsite visit to LLNL in February and March 1995. The evaluation does not include other sites administered by LLNL, nor did it include the Sandia facility just north of LLNL.

The key elements presented in this data validation report are: 
- $\quad$ Purpose and scope of the LLNL data validation effort

- $\quad$ Background information on LLNL

- Hazardous waste category definitions

- $\quad$ LLNL data submittal

- LLNL hazardous waste generators

- Treatment, storage, and disposal facilities (TSDFs) that received LLNL wastes

- $\quad$ Site-wide administrative procedures and controls

- $\quad$ Radiological control procedures

- Laboratory analysis and quality assurance/quality control (QA/QC) procedures

- Hazardous waste management procedures

- Waste handling and release criteria

- Data validation processes, including generator/shipper interviews and review of onsite and offsite shipment manifest records

- Traceability of individual radioassay sample results to onsite shipment manifests and then to offsite shipment manifests

- Data validation results

- Classification of validated items on offsite shipments using the data request criteria.

This report includes documentation necessary to support the data validation conclusions in appendices.

\subsubsection{LLNL Data Submittal}

In answer to the DOE-HQ data request and later modifications, LLNL prepared and submitted a summary of their hazardous waste shipments including waste types, amounts, and final TSDFs that received the waste. The term "data submittal" refers to the collection of information produced by LLNL for the data request and sent through a collection of letters, facsimile, and electronic submittals to the Radioactive Waste Technical Support Program (TSP). Hazardous waste shipments from LLNL from 1984 to 1991 included 2,205 manifests containing 4,906,858 $\mathrm{kg}$ of waste with a total volume of $18,936 \mathrm{~m}^{3}$.

For the reporting period 1984 to 1991, the LLNL reported 2,205 manifested waste shipments all of which they categorized as clean. The original data submittal listed more than 19,800 containers with more than 6,100 waste descriptions. Since LLNL labpacks or bulks much of its hazardous 
waste, the number of waste descriptions and containers has little correlation with the number of manifests generated during any given period. Table 1-1 gives a general idea of the amounts of hazardous wastes generated during the validation time frame. Table 1-2 lists the largest quantity waste streams (with greater than $80,000 \mathrm{lbs}$ generated in either 1990 or 1991) at the LLNL main site (LLNL 1991). While these waste streams are more than $70 \%$ of the total weight shipped during these years, they are only nine of the 156 waste streams listed for these years.

Sixty-two TSDF contractors provided prime disposal/brokerage services for LLNL. See Table 1-3 (Nakahara 1992). These prime TSDFs often shipped portions of the manifested waste to other TSDFs for further treatment or disposal. LLNL provided flowcharts to help identify final disposal TSDFs for the waste (Appendix A, Crawford 1992).

The data submittal contained a list of 76 waste items on which radioanalysis was done before its manifesting as hazardous waste from January 1990 through June 1991. See Appendix B. This corresponds to when routine shipments to the Nevada Test Site (NTS) stopped, making waste minimization, especially for radioactive waste, an immediate concern to all waste generators.

Before 1989, LLNL did not have local release criteria for waste disposal. Therefore, waste that had any potential, however small, of exposure to radioactivity was routinely shipped to the NTS for disposal. As the NTS Waste Acceptance Criteria (WAC) became more restrictive, and LLNL access to the NTS stopped for a time, LLNL began looking for ways to reduce the volume of material requiring disposal as radioactive waste. This led to establishing media-specific decision criteria for identifying material that contained radioactivity greater than detection limits or background. From 1989 to 1991 these criteria, by radiation type, were (Crawford, 1992):

\begin{tabular}{c|c|c|c} 
Matrix & Gross Alpha LOS & Gross Beta LOS & Tritium \\
\hline Aqueous & $2 \times 10^{-8} \mu \mathrm{Ci} / \mathrm{mL}$ & $6 \times 10^{-8} \mu \mathrm{Ci} / \mathrm{mL}$ & $3 \times 10^{-6} \mu \mathrm{Ci} / \mathrm{mL}$ \\
Oil & $5 \times 10^{-7} \mu \mathrm{Ci} / \mathrm{mL}$ & $2 \times 10^{-6} \mu \mathrm{Ci} / \mathrm{mL}$ & $2 \times 10^{-5} \mu \mathrm{Ci} / \mathrm{mL}$ \\
Soil and Sludge & $1 \times 10^{-6} \mu \mathrm{Ci} / \mathrm{g}$ & $3 \times 10^{-6} \mu \mathrm{Ci} / \mathrm{g}$ & $5 \times 10^{-6} \mu \mathrm{Ci} / \mathrm{g}$
\end{tabular}


Table 1-1. Hazardous wastes shipped and incinerated from 1984 to 1991 (tons).

\begin{tabular}{lccl}
\hline Year & Shipped & Incinerated & Total \\
\hline 1984 & $1,760.0$ & 69.5 & $1,829.5$ \\
1985 & $1,590.0$ & 28.95 & $1,618.95$ \\
1986 & $1,750.0$ & 6.4 & $1,756.4$ \\
1987 & $1,470.0$ & 6.7 & $1,476.7$ \\
1988 & $1,360.0$ & 15.0 & $1,375.0$ \\
1990 & 1240.4 & 0 & 1240.4 \\
1991 & 1476.6 & 0 & 1476.6 \\
\hline
\end{tabular}

Table 1-2. Large waste streams at LLNL in 1990 and 1991.

\begin{tabular}{|c|c|c|}
\hline \multirow{2}{*}{ Waste Description } & \multicolumn{2}{|c|}{ Waste Amount (tons) } \\
\hline & 1990 & 1991 \\
\hline Aqueous waste with low toxic organics. & 216.8 & 129.5 \\
\hline Aqueous acidic solutions with metals. & 77.4 & 65.9 \\
\hline $\begin{array}{l}\text { Water from onsite cleanup of chemical spills } \\
\text { and leaky drums. }\end{array}$ & 2.5 & 102.4 \\
\hline $\begin{array}{l}\text { Organic liquids from onsite research and } \\
\text { maintenance operations. }\end{array}$ & 46.1 & 29.2 \\
\hline Halogenated cleaning/degreasing solvents. & 13.6 & 45.6 \\
\hline $\begin{array}{l}\text { Soil and concrete from cleanup activities and } \\
\text { soil investigations. }\end{array}$ & 42.2 & 18.6 \\
\hline $\begin{array}{l}\text { Empty metal containers from onsite research } \\
\text { activities. }\end{array}$ & 47.8 & 50.0 \\
\hline $\begin{array}{l}\text { Inorganic aqueous solutions with high } \\
\text { dissolved solids. }\end{array}$ & 316.4 & 598.0 \\
\hline \multirow{2}{*}{$\begin{array}{l}\text { Labpacked surplus, out-of-date, or damaged } \\
\text { packages of laboratory chemicals and } \\
\text { discarded aerosol can from onsite research } \\
\text { and maintenance activities. }\end{array}$} & 107.7 & 27.6 \\
\hline & 870.5 & $1,066.8$ \\
\hline
\end{tabular}


Table 1-3. Commercial TSDFs used by LLNL

\begin{tabular}{|c|c|c|c|c|c|c|c|c|c|c|}
\hline \multirow[b]{2}{*}{ Prime TSD Name } & \multirow[b]{2}{*}{ EPA ID No. } & \multirow{2}{*}{ Service Type(s) } & \multicolumn{8}{|c|}{ Waste (kg) } \\
\hline & & & 1984 & 1985 & 1986 & 1987 & 1988 & 1989 & 1990 & 1991 \\
\hline $\begin{array}{l}\text { Altamont Sanitary Landfill } \\
\text { Livermore, CA }\end{array}$ & CAD981382732 & BROKR & 0.00 & 0.00 & 2268 & 567 & 0.00 & 0.00 & 0.00 & 0.00 \\
\hline $\begin{array}{l}\text { Anderson Solid Waste, Inc. } \\
\text { Anderson, CA }\end{array}$ & CAD981388952 & LFILL & 0.00 & 0.00 & 0.00 & 0.00 & 567 & 0.00 & 0.00 & 0.00 \\
\hline $\begin{array}{l}\text { Appropriate Technologies II } \\
\text { Chula Vista, CA }\end{array}$ & САТ080010101 & $\begin{array}{l}\text { RMETL/OWSEP/STABL } \\
\text { NEUTR/BROKR }\end{array}$ & 0.00 & 0.00 & 0.00 & 0.00 & 0.00 & 3263.1 & 6445.91 & 0.00 \\
\hline $\begin{array}{l}\text { B\&J Sanitary Landfill } \\
\text { Vacaville, CA }\end{array}$ & CAD 982042475 & BROKR & 0.00 & 0.00 & 0.00 & 0.00 & 0.00 & 0.00 & 486 & 0.00 \\
\hline $\begin{array}{l}\text { Baron-Blakeslee } \\
\text { Newark, CA }\end{array}$ & CAD074644659 & BLEND/DISTL/RECYC & 0.00 & 13124.2 & 1945.9 & 576.52 & 547.32 & 751.9 & 116.8 & 0.00 \\
\hline $\begin{array}{l}\text { Battery Disposal Technology } \\
\text { Clarence, NY }\end{array}$ & NYD000632372 & $\begin{array}{l}\text { INCIN/NEUTR/REDOX/ } \\
\text { PYROL/RECYC }\end{array}$ & 0.00 & 0.00 & 0.00 & 116.8 & 43.8 & 0.00 & 175.2 & 0.00 \\
\hline $\begin{array}{l}\text { Broco, Inc. } \\
\text { Rialto, CA }\end{array}$ & САT080022148 & $\begin{array}{l}\text { DEACT/STABL/NEUTR } \\
\text { /BROKR }\end{array}$ & 0.00 & 0.00 & 0.00 & 0.00 & 0.00 & 0.00 & 80.3 & 0.00 \\
\hline $\begin{array}{l}\text { California A.E.T.C. } \\
\text { Richmond, CA }\end{array}$ & СAT080014079 & BROKR & 0.00 & 0.00 & 0.00 & 0.00 & 0.00 & 0.00 & 0.00 & 248.2 \\
\hline $\begin{array}{l}\text { California Oil Recyclers } \\
\text { Newark, CA }\end{array}$ & CAD980695761 & $\begin{array}{l}\text { RECYC/THMTR/ } \\
\text { BROKR }\end{array}$ & 0.00 & 10774.7 & 9357.6 & 2673.6 & 0.00 & 0.00 & 0.00 & 0.00 \\
\hline $\begin{array}{l}\text { Casmalia Resources } \\
\text { Casmalia, CA }\end{array}$ & $\mathrm{CAD} 020748125$ & $\begin{array}{l}\text { LFILL/WETOX/STABL/ } \\
\text { NEUTR/BROKR }\end{array}$ & 4615.4 & 1912.6 & 0.00 & 0.00 & 0.00 & 0.00 & 0.00 & 0.00 \\
\hline $\begin{array}{l}\text { Chemical Waste Management } \\
\text { Emelle, AL }\end{array}$ & ALD000622464 & $\begin{array}{l}\text { RORGS/BLEND/LFILL/ } \\
\text { STABL/NEUT }\end{array}$ & 576.7 & 0.00 & 0.00 & 0.00 & 0.00 & 0.00 & 0.00 & 0.00 \\
\hline $\begin{array}{l}\text { Chemical Waste Management } \\
\text { Kettleman City, CA }\end{array}$ & САТ000646117 & $\begin{array}{l}\text { LFILL/NEUTR/STABL/ } \\
\text { CNTRT/BROKR }\end{array}$ & 59445.08 & 42868.80 & 23060.30 & 0.00 & 0.00 & 9090.4 & 10738.2 & 0.00 \\
\hline $\begin{array}{l}\text { Chemical Waste Management } \\
\text { Sauget, IL }\end{array}$ & ILD098642424 & $\begin{array}{l}\text { LFILL/TRTMT/INCIN/ } \\
\text { BROKR }\end{array}$ & 0.00 & 0.00 & 0.00 & 0.00 & 0.00 & 0.00 & 6304.9 & 0.00 \\
\hline $\begin{array}{l}\text { Cylinder Recon Co. } \\
\text { Kearny, NJ }\end{array}$ & NJD000632240 & BROKR & 0.00 & 0.00 & 0.00 & 214.2 & 0.00 & 0.00 & 0.00 & 0.00 \\
\hline $\begin{array}{l}\text { Diversified Systems, Inc. } \\
\text { Athens, TN }\end{array}$ & TND034547141 & INCIN & 0.00 & 0.00 & 0.00 & 0.00 & 0.00 & 0.00 & 3342 & 0.00 \\
\hline $\begin{array}{l}\text { Drew Resources } \\
\text { Berkeley, CA }\end{array}$ & CAD070148432 & $\begin{array}{l}\text { RECOV/TRTMT/ } \\
\text { BROKR }\end{array}$ & 0.00 & 0.00 & 0.00 & 0.00 & 0.00 & 416.1 & 810.3 & 14.6 \\
\hline $\begin{array}{l}\text { EG\&G Idaho, Inc. (U.S. DOE) } \\
\text { Scoville, ID }\end{array}$ & ID4890008952 & BROKR & & & & & & & & \\
\hline $\begin{array}{l}\text { E.I. DuPont \& Co. } \\
\text { Deepwater, NJ }\end{array}$ & NJD002385730 & $\begin{array}{l}\text { BIODG/NEUTR/CARBN } \\
\text { /OWSEP/PRECP }\end{array}$ & 0.00 & 0.00 & 0.00 & 0.00 & 0.00 & 0.00 & 0.00 & 668.4 \\
\hline $\begin{array}{l}\text { Englehard Industries West, Inc. } \\
\text { Anaheim, CA }\end{array}$ & $\mathrm{CAD} 000612150$ & BROKR & 0.00 & 0.00 & 0.00 & 7.3 & 0.00 & 14.6 & 29.2 & 7.3 \\
\hline $\begin{array}{l}\text { ENSCO } \\
\text { El Dorado, AR }\end{array}$ & ARD069748192 & INCIN/BROKR & 153.3 & 589.2 & 0.00 & 0.00 & 1156.1 & 29698.9 & 17914.43 & 3591.6 \\
\hline $\begin{array}{l}\text { ENSCO } \\
\text { Whitebluff, TN }\end{array}$ & TND980729305 & BROKR & 0.00 & 0.00 & 0.00 & 0.00 & 0.00 & 3460.4 & 0.00 & 0.00 \\
\hline $\begin{array}{l}\text { Environmental Pacific } \\
\text { Amity, OK }\end{array}$ & ORD980977334 & RECYC/BROKR & 0.00 & 0.00 & 0.00 & 0.00 & 0.00 & 0.00 & 0.00 & 1693.6 \\
\hline $\begin{array}{l}\text { Envirosafe Services of Idaho } \\
\text { Grandview, ID }\end{array}$ & IDD073114654 & LFILL/STABL & 0.00 & 0.00 & 32060 & 0.00 & 0.00 & 0.00 & 0.00 & 0.00 \\
\hline
\end{tabular}


Table 1-3. Cont'd.

\begin{tabular}{|c|c|c|c|c|c|c|c|c|c|c|}
\hline \multirow[b]{2}{*}{ Prime TSD Name } & \multirow[b]{2}{*}{ EPA ID No. } & \multirow[b]{2}{*}{ Service Type(s) } & \multicolumn{8}{|c|}{ Waste (kg) } \\
\hline & & & 1984 & 1985 & 1986 & 1987 & 1988 & 1989 & 1990 & 1991 \\
\hline $\begin{array}{l}\text { Erickson, Inc. } \\
\text { Richmond, CA }\end{array}$ & CAD009466392 & RECYC/BROKR & 0.00 & 0.00 & 0.00 & 0.00 & 0.00 & 0.00 & 1042.73 & 0.00 \\
\hline $\begin{array}{l}\text { Eticam } \\
\text { East Fernley, NV }\end{array}$ & NVD980895338 & BROKR & 0.00 & 0.00 & 0.00 & 0.00 & 0.00 & 2676.8 & 8590.2 & 2688.2 \\
\hline $\begin{array}{l}\text { Evans Drum Co. } \\
\text { Richmond, CA }\end{array}$ & CAD000415232 & RECYC/BROKR & 0.00 & 8085.5 & 4764 & 0.00 & 0.00 & 0.00 & 0.00 & 0.00 \\
\hline $\begin{array}{l}\text { Evergreen Oil } \\
\text { Newark, CA }\end{array}$ & CAD 980887418 & $\begin{array}{l}\text { THMTR/RECYC/ } \\
\text { BROKR }\end{array}$ & 0.00 & 0.00 & 0.00 & 2673.6 & 4678.8 & 2005.2 & 1336.8 & 2005.2 \\
\hline $\begin{array}{l}\text { Forward Incorporated } \\
\text { Stockton, CA }\end{array}$ & CAD 990794133 & BROKR & 0.00 & 7467.3 & 0.00 & 0.00 & 0.00 & 0.00 & 0.00 & 0.00 \\
\hline $\begin{array}{l}\text { Gibson Oil and Refining Co. } \\
\text { Bakersfield, CA }\end{array}$ & CAD980883177 & BROKR & 0.00 & 0.00 & 0.00 & 668.4 & 0.00 & 1336.8 & 668.4 & 0.00 \\
\hline $\begin{array}{l}\text { GNB, Inc. } \\
\text { Vernon, CA }\end{array}$ & $\mathrm{CAD} 097854541$ & BROKR & 0.00 & 0.00 & 0.00 & 0.00 & 0.00 & 0.00 & 0.00 & 7.3 \\
\hline $\begin{array}{l}\text { H\&H Ship Service } \\
\text { San Francisco, CA }\end{array}$ & CAD004771168 & RECYC/BROKR & 0.00 & 0.00 & 0.00 & 1701 & 0.00 & 481.26 & 401.05 & 0.00 \\
\hline $\begin{array}{l}\text { Haz Control Inc. } \\
\text { Gilroy, CA }\end{array}$ & CAD000628149 & NEUTR/STABL/RMETL & 0.00 & 0.00 & 0.00 & 0.00 & 0.00 & 0.00 & 843.6 & 0.00 \\
\hline $\begin{array}{l}\text { IT Corporation } \\
\text { Benecia, CA }\end{array}$ & CAD000060012 & LFILL/BROKR & 486 & 334044 & 2835 & 0.00 & 0.00 & 0.00 & 0.00 & 486 \\
\hline $\begin{array}{l}\text { IT Corp Oil Reprocess Facility } \\
\text { Martinez, CA }\end{array}$ & CAD000092619 & BROKR & 5347.2 & 668.4 & 0.00 & 0.00 & 0.00 & 0.00 & 0.00 & 0.00 \\
\hline $\begin{array}{l}\text { IT Corporation } \\
\text { Martinez, } \mathrm{CA}\end{array}$ & CAD000094771 & TRTMT/LFILL/BROKR & 39450.2 & 519164.44 & 35425.21 & 0.00 & 0.00 & 0.00 & 0.00 & 0.00 \\
\hline $\begin{array}{l}\text { Kinsbursky } \\
\text { Anaheim, CA }\end{array}$ & CAD088504881 & $\begin{array}{l}\text { RECYC/INCIN/NEUTR } \\
\text { LFILL }\end{array}$ & 0.00 & 0.00 & 0.00 & 0.00 & 0.00 & 0.00 & 0.00 & 7.3 \\
\hline $\begin{array}{l}\text { Laidlaw Environmental Services } \\
\text { Roebuck, SC }\end{array}$ & SCD981467616 & INCIN/REDOX/NEUTR & 0.00 & 0.00 & 0.00 & 0.00 & 0.00 & 0.00 & 2673.6 & 0.00 \\
\hline $\begin{array}{l}\text { Laidlaw Environmental Services } \\
\text { Greenbrier, TN }\end{array}$ & TND000645770 & $\begin{array}{l}\text { INCIN/LFILL/BLEND/ } \\
\text { STABL/ } \\
\text { BROKR }\end{array}$ & 0.00 & 0.00 & 0.00 & 0.00 & 0.00 & 1861.5 & 6239.4 & 3620.8 \\
\hline $\begin{array}{l}\text { LLNL Site } 300 \\
\text { Tracy, CA }\end{array}$ & CA2890090002 & BROKR & & & & & & & & \\
\hline $\begin{array}{l}\text { LLNL } \\
\text { Livermore, CA }\end{array}$ & CA2890012584 & BROKR & & & & & & & & \\
\hline $\begin{array}{l}\text { Micro Metallics Corp. } \\
\text { San Jose, CA }\end{array}$ & CAD069124717 & BROKR & 0.00 & 0.00 & 0.00 & 0.00 & 0.00 & 7.3 & 0.00 & 0.00 \\
\hline $\begin{array}{l}\text { Norris Industries } \\
\text { Los Angeles, CA }\end{array}$ & CAD097030993 & NEUTR/STABL/BROKK & 0.00 & 0.00 & 0.00 & 0.00 & 0.00 & 0.00 & 0.00 & 2270.3 \\
\hline $\begin{array}{l}\text { Oil Process Co. } \\
\text { Los Angeles, CA }\end{array}$ & CAD050806850 & $\begin{array}{l}\text { NEUTR/CARBN/ } \\
\text { CHOXD }\end{array}$ & 0.00 & 0.00 & 0.00 & 0.00 & 0.00 & 0.00 & 6778.9 & 668.4 \\
\hline $\begin{array}{l}\text { Omega Recovery Services } \\
\text { Whittier, CA }\end{array}$ & CAD042245001 & TRTMT/RECYC/OWSEP & 0.00 & 0.00 & 668.4 & 668.4 & 0.00 & 0.00 & 0.00 & 0.00 \\
\hline $\begin{array}{l}\text { Pen-Rob Corporation Landfill } \\
\text { Joseph City, AZ }\end{array}$ & AZ0000000150 & BROKR & 0.00 & 0.00 & 0.00 & 0.00 & 0.00 & 0.00 & 2315 & 0.00 \\
\hline
\end{tabular}


Table 1-3. Cont'd.

\begin{tabular}{|c|c|c|c|c|c|c|c|c|c|c|}
\hline \multirow[b]{2}{*}{ Prime TSD Name } & \multirow[b]{2}{*}{ EPA ID No. } & \multirow[b]{2}{*}{ Service Type(s) } & \multicolumn{8}{|c|}{ Waste (kg) } \\
\hline & & & 1984 & 1985 & 1986 & 1987 & 1988 & 1989 & 1990 & 1991 \\
\hline $\begin{array}{l}\text { Petroleum Recycler Corp. } \\
\text { Patterson, CA }\end{array}$ & CAD083166728 & RECYC/BROKR & 0.00 & 0.00 & 0.00 & 0.00 & 0.00 & 0.00 & 21.9 & $\overline{0.00}$ \\
\hline $\begin{array}{l}\text { Quicksilver } \\
\text { Brisbane, CA }\end{array}$ & CAD981424732 & RMETL/BROKR & 0.00 & 0.00 & 0.00 & 0.00 & 0.00 & 0.00 & 318.9 & 124.1 \\
\hline $\begin{array}{l}\text { R\&D Fabricating and } \\
\text { Manufacturing } \\
\text { Colfax, LA }\end{array}$ & LAD981055791 & INCIN & 0.00 & 0.00 & 0.00 & 21.9 & 0.00 & 219 & 146 & 0.00 \\
\hline $\begin{array}{l}\text { Ramos Environmental Services } \\
\text { West Sacramento, CA }\end{array}$ & CAD044003556 & BROKR & 0.00 & 0.00 & 0.00 & 0.00 & 0.00 & 0.00 & 668.4 & 0.00 \\
\hline $\begin{array}{l}\text { Rollins Environmental Services } \\
\text { Deer Park, TX }\end{array}$ & TXD055141378 & $\begin{array}{l}\text { INCIN/LFILI/OWSEP/ } \\
\text { FSUB/RECYC }\end{array}$ & 5718.5 & 0.00 & 49319.2 & 883.3 & 0.00 & 0.00 & 1708.2 & 0.00 \\
\hline $\begin{array}{l}\text { Romic Chemical Corp. } \\
\text { East Palo Alto, CA }\end{array}$ & CAD009452657 & $\begin{array}{l}\text { NEUTR/DISTL/EVAPR/ } \\
\text { LLEXT/ } \\
\text { BLEND }\end{array}$ & 1336.8 & 2968.8 & 1036.6 & 7907.2 & 4484.9 & 6456.8 & 6550.8 & 668.4 \\
\hline $\begin{array}{l}\text { Ross Electric of Washington, Inc. } \\
\text { Chehalis, CA }\end{array}$ & CAD980835268 & BROKR & 0.00 & 0.00 & 0.00 & 0.00 & 0.00 & 671.6 & 3061.3 & 0.00 \\
\hline $\begin{array}{l}\text { Safety Kleen } \\
\text { Oakland, CA }\end{array}$ & CAD 053044053 & BROKR & 0.00 & 0.00 & 0.00 & 0.00 & 0.00 & 313.9 & 2168.1 & 868.7 \\
\hline $\begin{array}{l}\text { Safety Kleen } \\
\text { Rancho Cordova, CA }\end{array}$ & CAT000613950 & BROKR & 0.00 & 0.00 & 0.00 & 0.00 & 0.00 & 0.00 & 0.00 & 14.6 \\
\hline $\begin{array}{l}\text { Safety Kleen } \\
\text { Salida, CA }\end{array}$ & CAT000613968 & BROKR & 0.00 & 0.00 & 0.00 & 0.00 & 0.00 & 0.00 & 43.8 & 80.3 \\
\hline $\begin{array}{l}\text { Solvent Services, Inc. } \\
\text { San Jose, CA }\end{array}$ & CAD059494310 & BROKR & 0.00 & 0.00 & 0.00 & 0.00 & 0.00 & 6172.1 & 45557.18 & 34150 \\
\hline $\begin{array}{l}\text { U.S. Ecology } \\
\text { Beatty, NV }\end{array}$ & NVT330010000 & $\begin{array}{l}\text { STABL/INCIN/NEUTR/ } \\
\text { LFILL }\end{array}$ & 0.00 & 7776 & 0.00 & 0.00 & 0.00 & 0.00 & 0.00 & 0.00 \\
\hline $\begin{array}{l}\text { USPCI } \\
\text { Clive, UT }\end{array}$ & UTD991301748 & $\begin{array}{l}\text { RMETL/INCIN/RECYC/ } \\
\text { LFILL/RORGS }\end{array}$ & 0.00 & 0.00 & 28497.51 & 74373.15 & 47497 & 49382.49 & 44402.2 & 12016 \\
\hline $\begin{array}{l}\text { USPCI } \\
\text { Waynoka, OK }\end{array}$ & OKD065438376 & $\begin{array}{l}\text { LFILL/EVAPR/NEUTR/ } \\
\text { STABL } \\
\text { REDOX }\end{array}$ & 0.00 & 0.00 & 0.00 & 0.00 & 0.00 & 3342 & 0.00 & 0.00 \\
\hline $\begin{array}{l}\text { Waste Oil Reprocess Facility } \\
\text { Oakland, CA }\end{array}$ & CAD000626515 & BROKR & 1336.8 & 1336.8 & 0.00 & 0.00 & 0.00 & 0.00 & 0.00 & 0.00 \\
\hline $\begin{array}{l}\text { West Contra Costa Sanitary } \\
\text { Landfill } \\
\text { Richmond, CA }\end{array}$ & CAD041844002 & BROKR & 50 & 1575.7 & 115 & 0.00 & 0.00 & 0.00 & 0.00 & 0.00 \\
\hline $\begin{array}{l}\text { Western Drums, Inc. } \\
\text { Hayward, CA }\end{array}$ & CAD087210399 & RECYC/BROKR & 0.00 & 0.00 & 0.00 & 17447 & 4022.3 & 5080.8 & 0.00 & 1562.2 \\
\hline TOTALS & & & 118515.98 & 952356.44 & 191352.72 & 110499.4 & 62997 & 126703 & 181979.7 & 67461 \\
\hline
\end{tabular}


LLNL listed all 76 of the items for they could easily obtain radioanalysis results as "suspect." All but three of the 76 items had either gross alpha, gross beta, or tritium levels greater than the criteria in force at the time. LLNL established these criteria at the level of sensitivity (LOS) (or at background for tritium in water) for each of these measurements. LLNL shipped a total of 16,235 items between January 1990 and June 1991. Based on the radioanalysis results of the 76 items, LLNL characterized $0.47 \%$ of the 16,235 items as suspect. This classification assumes all other items shipped were clean, even if a particular waste item came from the same process or location as waste identified as suspect based on radioanalysis results.

\subsection{LLNL History and Missions}

LLNL is about 40 miles east of San Francisco at the southeast end of the Livermore Valley in Southern Alameda County (Energy \& Technology 1994; University of California 1994a; University of California 1994b). The Laboratory was founded in 1952 with its primary mission to conduct nuclear weapons and controlled thermonuclear reaction research. Today, LLNL devotes much of its resources to defense programs, which include weapons and laser fusion research. Other major areas of focus are magnetic fusion energy, laser isotope separation, chemistry, engineering and physics research, biomedical and environmental sciences, applied energy technology, and work for other governmental agencies.

LLNL occupies essentially all (1.6 mi) of Section 12, T3S, R3E of the U.S. Geological Survey (USGS) Altamount Quadrangle, California (Figure 1-1). Agriculture remains the major land use east of the LLNL, but land to the north and west is being developed for residential and light industrial uses. The LLNL shares East Avenue with Sandia National Laboratory, with which it also shares facilities such as fire protection, a cafeteria, parking lots, and utilities. The City of Livermore is about 3 mi to the west.

LLNL also manages Site 300 , which is an $11-\mathrm{mi}^{2}$ test facility about 18 miles southeast of the LLNL main site in the Diablo mountain range. It was set up as a remote explosives facility to support theoretical and developmental work performed at the LLNL main site. Portions of Site 300 used to support these activities include the firing and test areas, chemistry and process areas, and general administration and support areas. The area surrounding Site 300 is sparsely populated, with most of the land used to support sheep and cattle ranching operations.

Before 1942, the property presently occupied by LLNL was part of the Wagoner Ranch and used for grain production and cattle grazing. In 1942, the U.S. Department of the Navy bought the property to develop Livermore Naval Air Station (NAS) and an adjoining ancillary gunnery range. The missions of the NAS included flight-training, aircraft assembly, and repair work activities. These missions continued until October 1946 when the Livermore NAS was deactivated following the end of World War II. In 1950, the Navy permitted the Atomic Energy Commission (AEC) to conduct research operations on the property, and formally transferred it to the AEC in January 1951. In September 1952, the site was established as the Livermore Branch of the University of California (UC) Radiation Laboratory. In December 1979, the Congress renamed the site the Lawrence Livermore National Laboratory. 


\begin{tabular}{|c|}
\hline $\begin{array}{l}\text { Legend } \\
\begin{array}{|l}\text { 闻 Badge Office } \\
\text { Eate } \\
\text { Pafeteria } \\
\text { Parking }\end{array}\end{array}$ \\
\hline
\end{tabular}

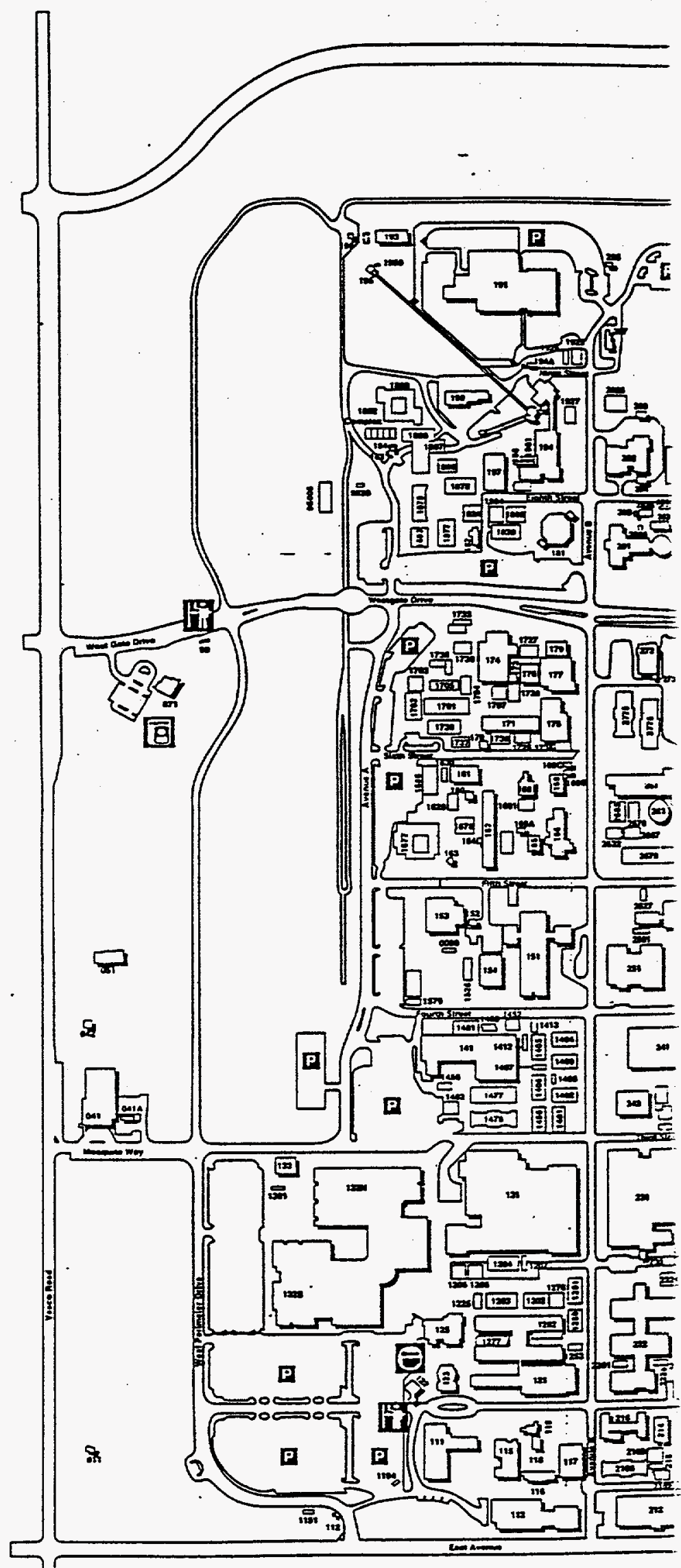

Figure 1-1. LLNL site map. 
back of fold out 


\subsubsection{LLNL Missions}

Over the years, the LLNL mission has evolved to include many activities:

- Research, development, and test activities associated with all phases of the nuclear weapons life cycle and related tasks

- Strategic defense research emphasizing kinetic- and directed-energy weapons

- Inertial confinement fusion for weapons physics research and civilian energy applications

- Atomic vapor laser isotope separation for defense and commercial applications

- Magnetic fusion, including leadership of the United States effort on the International Thermonuclear Experimental Reactor

- Other energy research in basic energy sciences, atmospheric sciences, fossil energy, and commercial nuclear waste, biological, ecological, atmospheric, and geophysical science

- Charged-particle beam and advanced laser and optical research for defense and energy applications.

Current major programs are defense and related programs, laser fusion, laser isotope separation, magnetic fusion energy, biomedical and environmental research, energy and resources, and Environmental Restoration and Waste Management. We briefly describe these programs below (Energy \& Technology 1994; University of California 1994a; University of California 1994b) to aid in the understanding of the processes that generate hazardous waste at the LLNL.

1.2.1.1 Defense Programs. The defense program develops and maintains the capabilities and technologies required to offer the range of options for future weapons systems and provides technical support for national goals in verification and arms control. The following paragraphs describe the major LLNL defense program elements.

\section{Nuclear Design}

This subprogram carries out theoretical and experimental research in the physics of fission and thermonuclear explosives. It is responsible for exploring new ideas for advanced development of nuclear explosives and maintaining a basic understanding of weapons phenomena.

\section{Nuclear Test-Experimental Science}

This subprogram is responsible for conducting experimental underground detonations of nuclear weapons designs at the NTS safely. It also performs physics experiments and measurements, including radiochemical measurements in support of these experiments.

\section{Military Applications}

This subprogram is responsible for the advanced development of weapons systems, including physics and engineering, and surveillance in production, stockpile, and retirement. It is also 
responsible for the Advanced Conventional Weapons Program and analysis related to nuclear and conventional weapons systems.

\section{Strategic Defense Initiative}

The mission of this project is to conduct research for the technological advancement of a strategic defense system known as Brilliant Pebbles. This defense concept would place small spacecraft into a low earth orbit. These spacecraft could detect and destroy ballistic missiles through high velocity collisions.

1.2.1.2 Laser Fusion. In laser fusion, an array of high-power lasers focuses on a tiny sphere containing a mixture of deuterium and tritium gases. The goal is to compress the gases to a high enough temperature for a long enough time for the deuterium and tritium nuclei to fuse and release significantly more energy than contained in the high-powered lasers. The near-term mission of the laser fusion program is to provide a laboratory capability to study problems important to thermonuclear weapons design and performance. The long-term goal is to develop Inertial Confinement Fusion reactors for commercial power, space propulsion, and other military and civilian applications. The areas investigated include details of thermonuclear burn, the radiation, thermodynamic, and hydrodynamic properties of materials at high temperatures and densities, physics principles of advanced nuclear weapons concepts, physics of nuclear effects, and vulnerability of mechanical and electrical systems to those nuclear effects.

1.2.1.3 Laser/sotope Separation. The goal of the Atomic Vapor Laser Isotope Separation (AVLIS) program is to develop and demonstrate a process for the separation of isotopes of various materials. In this process, a material consisting of a mixture of isotopes is heated and vaporized. Laser light directed on the vapor selectively ionizes isotopes of interest, which are collected on electrically charged plates. DOE is studying additional applications for AVLIS technologies in the general areas of isotope separation, beam separators, lasers, and electro-optics with the key aim of commercializing these technologies.

1.2.1.4 Magnetic Fusion Energy. The magnetic fusion energy program helps in the development of magnetic fusion technology as part of an effort to harness thermonuclear fusion for energy production. In magnetic fusion, electromagnetic induction heats a cold plasma of ions and electrons confined by magnetic fields. If a plasma of deuterium and tritium can be kept at a sufficiently high temperature for a long enough period, their nuclei will fuse and yield energy. The primary thrust of fusion development is to achieve the successful confinement of a burning thermonuclear plasma under conditions expected in a power-producing fusion reactor.

1.2.1.5 Biomedical and Environmental Research. The mission of the biomedical and environmental research program is to understand the potential health and environmental effects of developing and using various energy sources. In particular, LLNL is finding ways to identify and measure genetic damage as an indicator of human health effects. LLNL is also examining local- and global-scale environmental changes involving the atmosphere and studying a variety of ecological effects resulting from energy production and use. An area of growth in current biological research is the human genome initiative, an international effort to map the human genetic code. 


\section{WASTE CATEGORY DEFINITIONS}

\subsection{Premoratorium Definitions}

From 1984 to 1991 , DOE required generators to survey wastes to be sure no detectable external radiation or surface contamination existed as defined in DOE Order 5400.5. Before imposing the moratorium in May 1991, DOE had not established an acceptable limit of detectable radioactivity within the waste volume or bulk. Because no complex-wide limits existed, DOE Management and Operations (M\&O) contractors at each site set up their own procedures for determining whether a waste package was suitable for offsite shipment as nonradioactive waste.

\subsection{DOE-HQ Moratorium Definitions}

The DOE-HQ moratorium data request asked the DOE sites to categorize the waste shipments as known radioactive, clean, likely radioactive, or likely clean using the criteria in the following subsections. The data request provided guidance for assigning these categories. Figure 2-1 illustrates the process for classifying these wastes.

\subsubsection{Radioactive Waste}

Radioactive waste is any waste with radioactivity added to the volume or bulk of the waste because of DOE operations. The addition of radioactivity may be shown by (a) material use history (i.e., use in a radioactive system or radioactive spill recovery), (b) sampling and analysis results showing radioactivity above background (background includes natural levels of radiation in materials), or (c) waste that has excessive surface contamination due to DOE operations as shown by surface survey results. Waste suspected to be radioactively contaminated through material use history must be sampled to find out the activity content of the sample. For many wastes, internal contamination by radioactivity is unlikely, but they are in radioactive materials management areas (RMMAs) where external contamination is possible. For these wastes, a surface contamination survey must be done, with results compared to surface contamination limits in DOE Order 5400.5. DOE-HQ defined a nonradioactive waste as a waste that meets the following conditions (DOE 1993):

- The waste contains no added radioactivity (at a $95 \%$ confidence level above background) in volume or bulk resulting from DOE operations [except wastes specifically exempted by the U.S. Environmental Protection Agency (EPA), DOE, or Nuclear Regulatory Commission (NRC) regulations]

- The waste has no surface radioactivity above limits established in DOE Orders or guidance [e.g., surface contamination limits and requirements of DOE Order 5400.5, II.5.c.(1)].

\subsubsection{Clean Waste}

Many DOE operations do not occur in an RMMA or have the potential for adding radioactive contamination to waste material. Clean waste is waste that comes from outside an RMMA and has surface contamination levels less than DOE Order 5400.5 guidelines. Clean wastes can include wastes that come from within an RMMA if documented evidence of administrative controls, process knowledge, or sampling and analysis results can prove these wastes clean, showing no activity above background levels. Sampling and analysis results, survey results, or administrative and material history documentation are necessary to characterize a waste as radioactive or clean. 


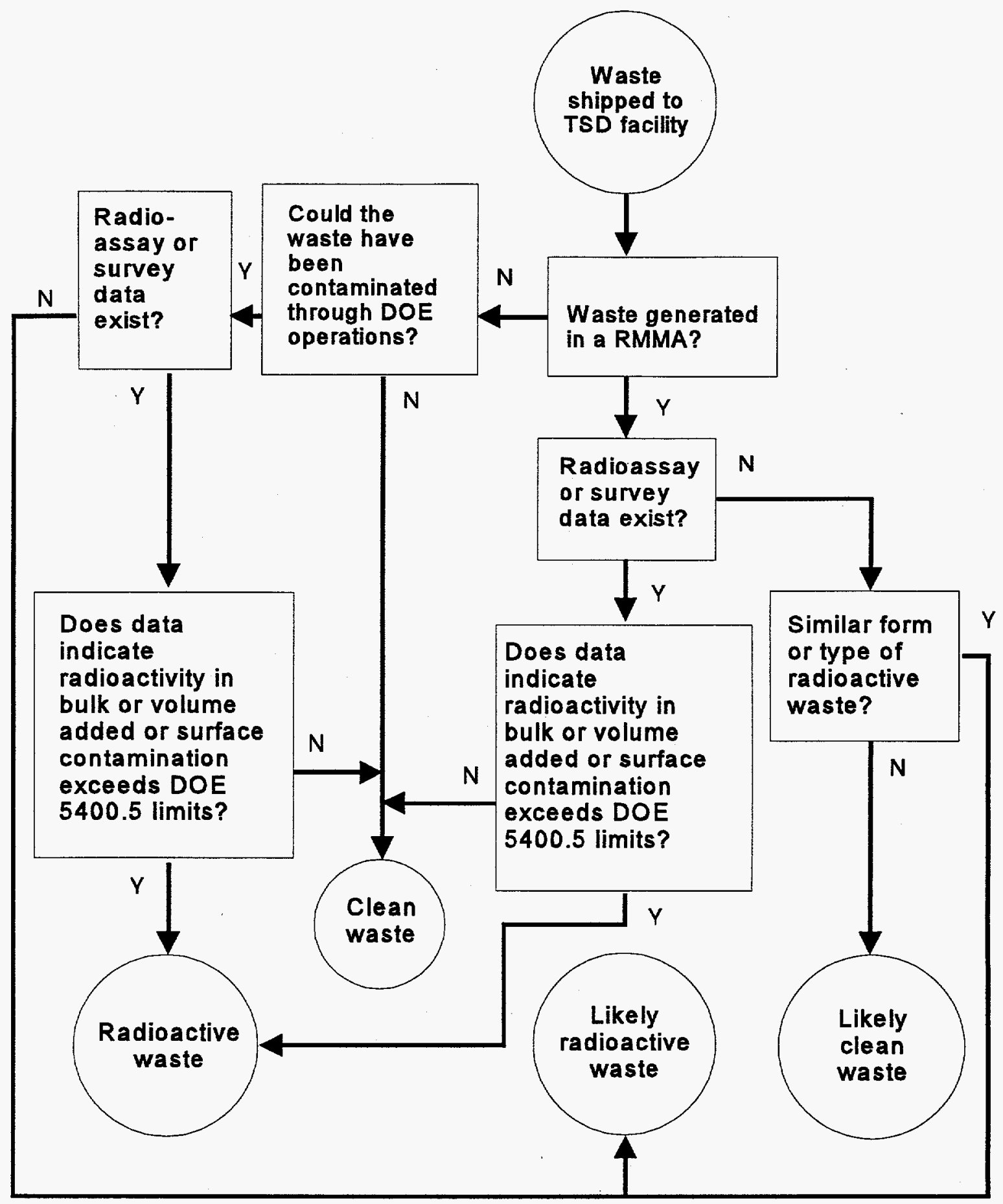

Figure 2-1. DOE waste classification decision tree. 


\subsubsection{Likely Radioactive Waste}

Likely radioactive wastes are wastes shipped from LLNL that have limited retrievable documentation of sampling and analysis, survey results, administrative control, or material history documentation to enable classification of the waste as either radioactive or clean. Wastes classified as likely radioactive waste are wastes that are similar in form or type and originate from the same process or area as wastes classified as known radioactive. Wastes classified as likely radioactive mean that DOE operations may have added radioactivity to the volume or bulk of the waste or that surface contamination may exceed DOE Order 5400.5 guidelines.

\subsubsection{Likely Clean Waste}

Similar to likely radioactive waste, likely clean waste is waste from an RMMA and similar in form or type and origin to wastes classified as clean. For these wastes, documented evidence of administrative controls, process knowledge, or analytical data is not available to show DOE operations added no radioactivity to the waste bulk or volume. Nor does evidence exist to verify the surface contamination is less than DOE Order 5400.5 guidelines. 


\section{LLNL WASTE HANDLING}

The evaluation team determined the correct categories of hazardous wastes shipped from LLNL before the moratorium in two ways. First, the team examined the processes and procedures used for classifying and handling wastes generated from 1984 through 1991. Second, specific waste shipments with available radioanalysis results were investigated. Section 3 looks at organization, waste handling practices, and sampling and analysis procedures; Section 4 describes the investigation of specific shipment items. Information on processes and procedures is inexact as they changed significantly through the validation period (1984 to 1991) and continued to change through today. Issues raised, therefore, reflect conditions at LLNL during the premoratorium validation time-frame and not present conditions or practices.

\subsection{Organization and Waste Handling}

Waste management at LLNL relied not only on the generator but also contributions from services provided throughout the site. Waste management technical support comes from, among others, safety professionals, health physics, and laboratory analysis organizations. Figure 3-1 shows the LLNL organization in 1989, midway through the validation period. Figure 3-2 is the current organization for the Environmental Protection Department (EPD). The Hazardous Waste Management (HWM) Division of the EPD has primary control of hazardous waste management.

The HWM Division staff performs the following functions:

- $\quad$ Processes, stores packages, solidifies, treats, and prepares waste for shipment and disposal or recycling

- Tracks and documents the movement of hazardous, mixed, and radioactive waste from Waste Accumulation Areas (WAAs) to final disposal, both on and offsite

- Helps the programs in evaluating waste for waste minimization through reduction of wastes generated, substitution of materials, and recycling

- Decontaminates laboratory equipment

- Meets with Federal, State and local regulators about the permitting and compliance of hazardous waste management facilities

- $\quad$ Ensures containers for shipment of wastes meet Department of Transportation (DOT) and other regulatory specifications

- Responds to emergencies and participates in the cleanup of hazardous and radioactive spills at the Livermore Site and Site 300

- Prepares the annual LLNL Waste Management Plan.

The HWM Quality Assurance Plan (QAP) describes approval authority for waste management. Many other documents guide and support the waste management program at LLNL, including Federal and State regulations, DOE Orders, and LLNL program plans and procedures. 


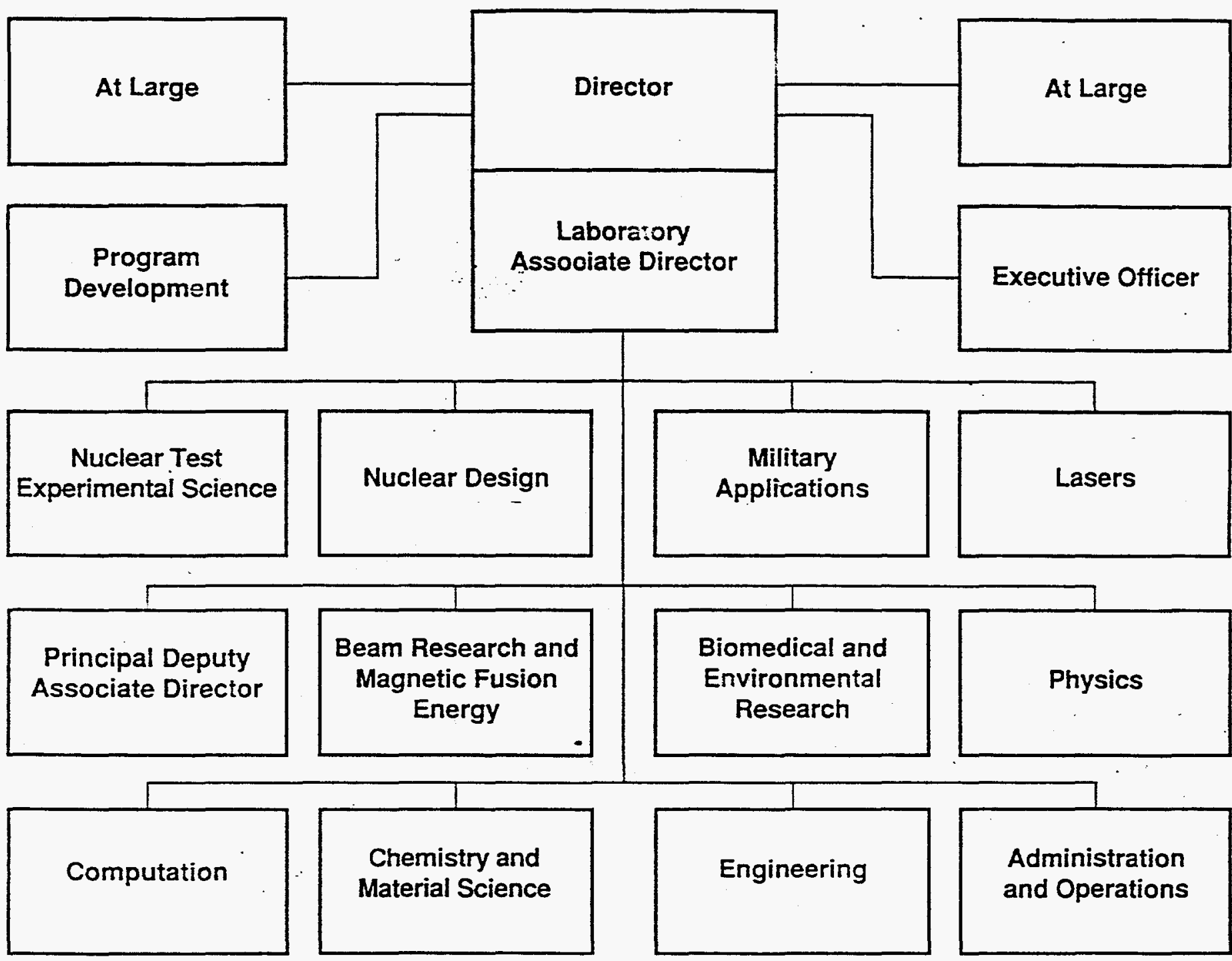

Figure 3-1. LLNL organization chart. 


\section{ENVIRONMENTAL PROTECTION DEPARTMENT \\ Department Head: Harry L. Galles \\ Deputy Department Head: Ellen Raber}

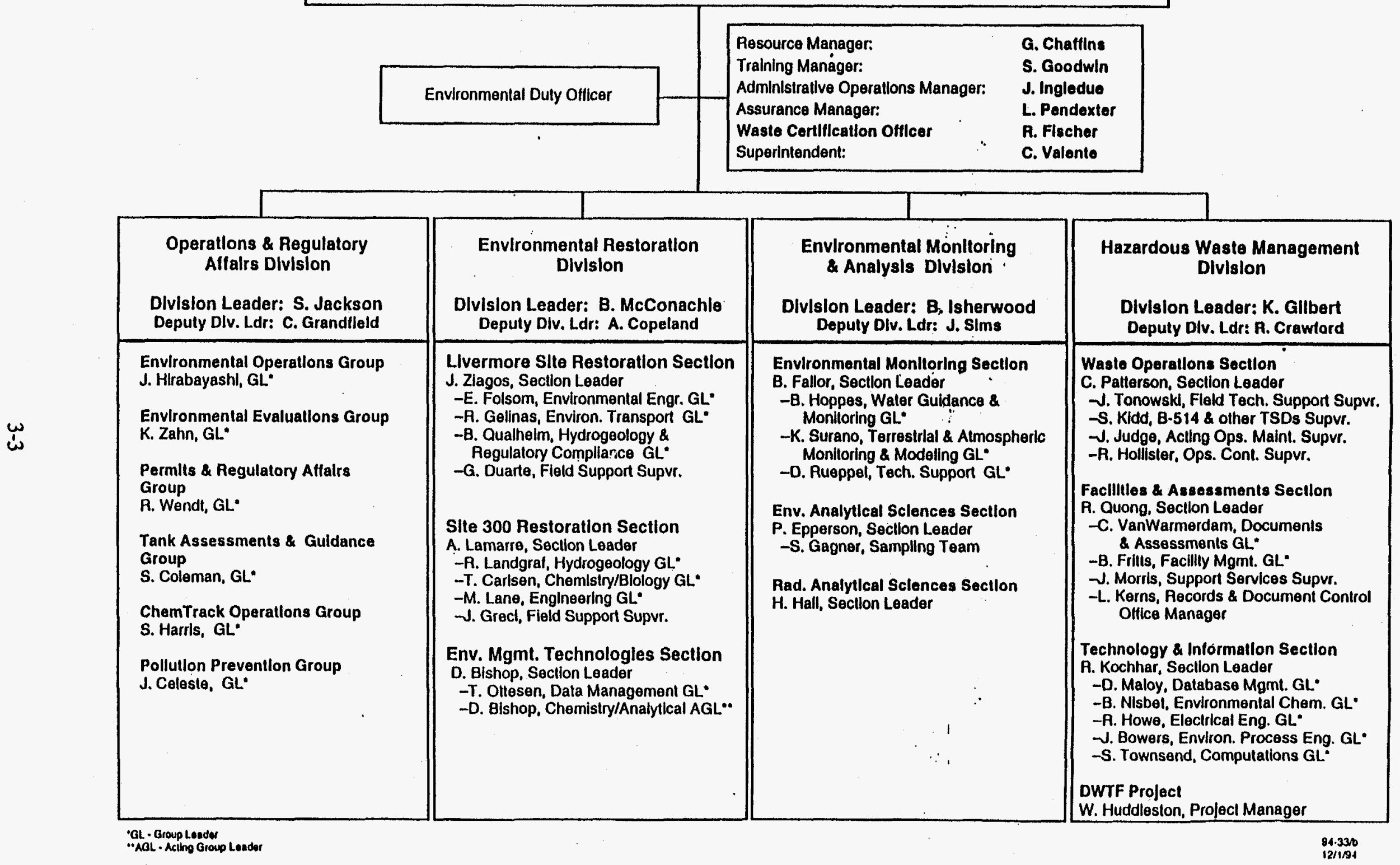

Figure 3-2. EPD organization. 
Much of the waste generated at LLNL for disposal as hazardous waste is the result of the experimental laboratory operations at the site discussed in Section 1.2. These operations are very diverse and variable, resulting in hazardous waste streams that are also numerous, diverse, and variable. Much of the individual wastes from LLNL laboratories are generated in small quantity and laboratory packaged (lab packed) with wastes from other labs for shipment to a TSDF. Large scale waste streams at LLNL are acids, bases, solvents, and rinse waters from metal treatment operations (including radioactive metals).

Currently, the waste generator classifies the waste stream using process knowledge or sampling and analysis results, and fills out the required paperwork with health and safety (H\&S) technicians, health physicists (HPs), or HWM technicians. Small volume wastes then go to a WAA for temporary storage before transfer to HWM facilities for repackaging (as required), manifesting, and shipment to commercial TSDFs. Large volume wastes (e.g., hazardous retention tank waste waters) are manifested and shipped directly from the point of origin. The remainder of Section 3 discusses details, exceptions, and changes to this general waste handling procedure over the validation time frame.

LLNL developed RMMAs in 1991 after DOE enacted the shipping moratorium. Before 1991, Radioactive Material Areas were designated to monitor radioactive exposure to personnel but were not intended to manage whether radioactivity was added to waste by DOE operations. A database was started in July 1991 to track the rooms in buildings designated as RMMAs. This database is updated monthly as RMMA designations change periodically. Appendix $\mathrm{C}$ contains a list of buildings and rooms that contained RMMAs in 1991. The appendix also includes a list made in 1991 of buildings that contained RMMAs, or may have contained RMMAs, in the years before creation of the list.

The facility manager establishes individual RMMAs by requesting that an area be designated an RMMA. Then the H\&S team for that facility reviews the request. An HP from H\&S will inspect the new RMMA and will establish both radiation controls for personal exposure and review controls for waste hancïing and disposition. H\&S techs will visit the new RMMA regularly to survey for radioactivity and take swipes for contamination control.

Each H\&S team has an action plan that is a controlled document to establish the routines for surveys, swipes, contamination control and waste disposition. Only one copy of each team action plan is available. Included in this team action plan are procedures to remove waste and materials from an RMMA for free release or controlled release. The HP, the facility manager, closes out an RMMA by using process information, collecting smears, and performing surveys to show that radioactive contamination is not present above known background. These procedures for establishing an RMMA and certifying each RMMA closed were formalized in 1991. Before that time Radioactive Material Areas designated locations where radioactive material was present. Formalized procedures for the closeout of an RMMA may have been lacking because the DOE-HQ Tiger Team audit findings suggested that many laboratory experiments were left in place long after the experimenter had ended a specific program.

\subsection{Waste Sampling and Analyses}

Before the shipping moratorium in 1991, procedures for waste sampling and analysis were not well documented. Waste generators historically had the duty of deciding if a waste could potentially contain added radioactivity. Before 1991, the generator made requests for sample analyses on wastes. The sample analyses requested by the generator often did not include radiological analyses, most likely because of generator process knowledge. Analytical results were 
most often requested on liquid wastes intended to be released to the City of Livermore sewage system.

From 1984 to 1991, sampling and analysis of waste streams to detect the presence and quantify hazardous and radioactive constituents were not consistent throughout LLNL. The waste generators provided much of the knowledge about the waste streams without sampling data and consistent review by HWM or Hazards Control Department (HC). The basis of this determination is internal LLNL audit reports including the Independent Environmental Safety and Health (ES\&H) Review Team Findings from October 1989 (an audit in preparation for the DOE-HQ Tiger Team) and the DOE-HQ Tiger Team findings.

Sampling and analysis were used sometimes to characterize waste streams. The evaluation team examined the sampling and analysis methods along with analytical results to provide an assessment of the quality of hazardous waste characterization. The sampling and analysis program did not include procedures to determine background concentrations of naturally occurring radionuclides or develop guidelines for developing sampling criteria and procedures. Nor were there procedures to establish a basis for sample frequency, definition of allowable error, or specification of a confidence interval.

In 1989, the HWM Control Lab, predecessor to Environmental Analytical Services (EAS), was formed to provide consistent sampling and analysis techniques for waste. EAS began by preparing procedures for sampling various waste streams, using SW-846 procedures for analysis of hazardous wastes and to send samples for radioassay to the HC or HWM laboratories. EAS only sent those samples to radioassay if the generator requested it or if surveys of the sample showed the presence of radioactivity above the field survey threshold.

\subsubsection{Sampling Methods}

Sampling methods are an important part of waste characterization. Since LLNL had no consistent sampling methods, the evaluation team is concerned that waste streams were not sampled or were sampled improperly. Sampling error contributes significantly to the total error in sampling and analysis. The team recognizes that in some waste streams achieving representative samples is difficult. An example is laboratory wastes, which comprised many identified waste streams. LLNL was developing consistent sampling methods in 1989 and 1990, but these were not used for the entire laboratory until after the DOE-HQ Tiger Team visit in 1990.

Identification of wastes that require sampling is an important part of waste characterization. Identification of wastes requiring sampling was also inconsistent and largely dependent on the generator of the waste. Waste profiling characterized a waste stream or process knowledge identified the waste. The profile was used for all waste generated by this process. Without periodic sampling or consistent sampling methods, these waste profiles could have been in error. In 1991, a waste characterization profile verification sampling and analysis program was started where wastes are periodically sampled independently to ensure waste profiles are up-to-date.

On-the-job training was given to technicians who collected tank samples. However, audits conducted by on- and off-site personnel during the time of interest suggested that samples from tanks were often collected without a consistent sampling approach and without mixing the tank contents to gain a representative sample. Samples collected from tanks without mixing or without collecting samples at various depths can lead to large errors attributable to sampling methods.

Knowledge of the waste characteristics at LLNL is very dependent on the waste generator to 
supply information to HWM for disposal. The dependence on generators at LLNL to be the primary contact for waste characteristics has many limitations. Many findings by the DOE-HQ Tiger Team showed the dependence on generator knowledge limited LLNL's ability to characterize waste adequately. The findings listed below are from the DOE-HQ Tiger Team audit of LLNL. This is not a complete listing of findings on waste characterization, but shows the LLNL process during 1990.

- LLNL does not have methods, facilities, equipment, or procedures to segregate contaminated waste from clean waste after the waste has been generated.

- LLNL did not have a laboratory-wide closeout procedure for individual laboratories when researchers left or when experiments ended. The research at LLNL involved many individual researchers and experiments. Often when a researcher leaves or when the project ends, the used or unused chemicals and radioactive materials were simply left behind in the laboratory. The chemicals, if the original researcher did not dispose of them, may remain for years. If personnel other than the researcher disposed the waste, it may result in improperly characterizing waste as hazardous, radioactive or mixed waste.

- $\quad$ Neither the existing HWM QAP nor any other LLNL QAP establishes methods for review and evaluation of the waste characterization done by the generator. The HWM qualitatively reviews the completed requisition forms and associated analysis, if any, to identify obvious and gross characterization problems. However, this provides no quantitative indication of the accuracy and completeness of the generator's characterization effort. LLNL has neither required nor performed routine audits and surveillance of generator waste characterization activities. QC checks are not performed to verify the accuracy and completeness of generator characterization by opening, sampling, and analyzing a fraction of all waste containers received. No other types of waste characterization QC checks are performed.

- The indirect methods used to characterize low-level waste (LLW) are not defined and documented by waste stream. Methods, associated documentation, and quality assurance are not adequate to prove the indirect methods can be correiated with actual measurements. The generator can obtain assistance in LLW characterization from the HWM and the building HP; however, there are no specific requirements about this involvement. Building H\&S technicians may also help in the characterization process, but their role is not explicitly defined.

- A formal program for the characterization of LLW does not exist, and there are no specific documentation requirements. No specific guidance exists that requires sampling and analysis of all LLW. Nor is there any mechanism to identify and approve waste streams for exemption from sampling and analysis. No mechanism exists to evaluate the adequacy of indirect quantification methods for waste streams exempted from sampling and analysis.

- Hazardous waste, mixed waste, LLW, and clean waste containers or some combination of these are often found in the same area in some buildings. The generator is responsible for determining in which receptacle each waste belongs and for characterizing that waste; however, there are no established formal methods or procedures to ensure these activities are performed in a way that meets the performance objectives. Personnel are trained in this area and waste types are often discussed in the Facility Safety Procedures (FSPs), but there are no performance indicators or QAPs that verify the effectiveness of this training or the FSP. 


\subsubsection{Analytical Methods}

At most DOE facilities, procedures for analytical methods for any given year are not easily available because outdated procedures must go to a central records repository. This is also the case for LLNL. Three methods the evaluation team used to review analytical procedures are: (1) reviewing audit findings on old procedures, (2) interviewing personnel familiar with the procedures, and (3) using existing procedures as an indicator of past practice.

The HC laboratory or Nuclear Chemistry analyzed samples of hazardous waste material for offsite shipment. The HC laboratory continues to-operate but the laboratory analysis procedures used between 1984 and 1991 were unavailable to the validation team during the site visit. Procedures and $\mathrm{QA} / \mathrm{QC}$ requirements have changed since the laboratory began operation. We assume in this report that the historical analytical procedures used by the two laboratories were similar. Analyses performed at the HC laboratory included gross alpha/beta and tritium analysis. Gross alpha/beta analysis was performed on solid and liquid samples.

The validation team used information from the DOE-HQ Tiger Team audit of 1990 and LLNL internal audits performed during 1989 and 1990, interviews with analytical personnel at HC and HWM and Nuclear Chemistry, and a review of existing procedures. Interviews with analytical chemistry personnel suggested the analytical procedures in use today are probably similar to those used in the past. Very few personnel had direct experience with radioanalytical procedures before 1991. The only changes in procedures were thought to have been in QA/QC elements in each method or QA/QC elements of the laboratory. This is based on interviews with personnel at LLNL.

A review of analyses of wastes dated in the premoratorium time frame suggested the LOS of the analytical methods was marginal for some sample matrices. The gross alpha LOS of $20 \mathrm{pCi} / \mathrm{mL}$ could be as low as $10 \mathrm{pCi} / \mathrm{mL}$, based on measurements using comparable instruments. The LOS reported in 1992 as representative of LOS from 1984 to 1991 may be very good for some analyses and marginal for others. The gross alpha analysis $\mathrm{LOS}$ for water is $20 \mathrm{pCi} / \mathrm{L}, 5 \mathrm{pCi} / \mathrm{L}$ greater than the Safe Drinking Water Act standard [40 Code of Federal Regulations (CFR) 141]. The gross alpha analysis for soil is very good at $1 \mathrm{pCi} / \mathrm{g}$. Very little alpha spectroscopy analysis was performed on any waste samples to verify the gross alpha analysis.

The gross alpha LOS is significant because only once in review of the data from Hazardous Waste Disposal Requisitions (H-Reqs) did the validation team find any isotopic analysis. The validation team found many examples where, when samples were greater than the LOS, the associated wastes were shipped offsite without isotopic analysis to differentiate between DOE-added radioactivity and natural background. This suggests that other analytical techniques were not used to distinguish between naturally occurring and anthropogenic radionuclides.

Several deficiencies identified in previous audits of counting labs that were part of $\mathrm{HC}$ and HWM or performed work for HC and HWM from 1989 and 1990 include:

- The person performing the calibration did not sign calibration logs

- Incoming samples were placed on a bench top in an unsupervised area

- The analyst did not always sign analytical log sheets, which does not allow clear traceability of changes or deletions

- No formal procedure existed for validation of all analytical data generated 
- $\quad$ Spiked, blank, and duplicate samples were used as QC checks, but the results were not trended, and there were no formally defined acceptance criteria.

- No documentation specified a minimum number of QC samples, and no definition of what QC samples were required by sample and analysis results.

- QC samples were not processed as blind samples.

These audit findings suggest procedural changes were needed to provide reliable data. Although these audit findings are important for laboratory operations, they do not much affect the validation team's effort to categorize waste because LLNL collected so little data on hazardous waste shipments. The reliance on process knowledge from generators reinforced the lack of radioanalytical data. The validation team did find sampling and analysis of tank waste was performed frequently and sampled more than other waste streams. Sampling and analytical QA/QC problems identified would have a much greater chance of affecting the final disposal choice for tank wastes.

\subsection{Sample Collection Data}

To be sure the sampling, analytical, and QA/QC procedures were adequate, the validation team revised a checklist from the EPA document Guidance for Data Useability in Risk Assessment (Part B) (EPA 1992). This document provides concise guidance for the analysis of radionuclides and the QA/QC requirements for this type of data, also providing supplemental information about the useability of the data. References used for preparation of the Guidance for Data Useability in Risk Assessment (Part B) include American Society for Testing and Materials (ASTM) Standards, DOE Radiation Measurements Procedures Manuals, and EPA Radiochemical Analytical Procedures. The QA/QC requirements that relate directly to the Superfund Program were dropped from the checklist, so only standard QA/QC criteria were included. The following is the modified checklist.

\section{Sample Collection}

Q. How were samples collected?

Were Standard Operating Procedures (SOPs) developed?

Were the samples representative?

A. Information about sample collection techniques used by generators was lacking. There were no formalized procedures for sample collection, as noted in an audit of the HWM and HC programs before the DOE-HQ Tiger Team visit. Serious problems may result if the collected sample is not representative of the material to be released from radiological controls. No documentation was found to show adequate field sampling protocols were developed or reporting forms were used during the period between 1984 and 1990. Sampling protocols were established and consistently followed in 1991.

\section{Shipping/Transmittal Forms}

Q. Were shipping forms used?

A. Shipping/transmittal [sample chain-of-custody (COC)] forms between the field sampling personnel and laboratory are available for only part of the samples from the time frame in question. Sample COC forms include the sample identification number, sampler, sample description, and generator record. 


\section{Sample Receipt Logs}

Q. Were sample receipt logs kept?

A. It is clear from internal auditor remarks and references in some SOPs that samples were logged in and numbered in the years from 1987 to 1991.

\section{Laboratory Analysis Request and Distribution Forms}

Q. Were analysis request forms used by samplers?

A. Laboratory analysis request forms were prepared for the submitted samples during the years of 1989 to 1991 . For other years, the analysis to be performed was verbally communicated to laboratory personnel and then written in the sample receipt logbooks.

\section{Radiation Screening Information}

Q. Was radiation screening information provided to the laboratory?

A. The team found no evidence that field screening information was passed on to the laboratory regularly, although radiological survey information was collected and entered into health physics logbooks. If the generator knew the waste was potentially contaminated based on process knowledge, or the field survey detected radioactivity greater than background, it was shipped as radioactive waste to the NTS. Minimal analysis was performed.

\subsubsection{Analytical Data}

\section{Standards Preparation and Traceability}

Q. Were SOPs for standards preparation available and were the standards traceable to a national standard?

A. Standards were initially prepared in the laboratory using laboratory SOPs, but some standards were not traceable to a national standard.

\section{Calculation of Efficiencies}

Q. Were efficiencies of instruments calculated and at what frequency?

A. The efficiency of detectors was calculated and reported to internal auditors. It was suggested quarterly efficiency and weekly calibration checks be performed by the laboratory.

\section{Concentration/Dilution Factors}

Q. Were concentration or dilution factors noted as necessary for specific analyses?

A. SOPs for instrument operation suggest calculations accounted for samples that required concentration or dilution. 


\section{Evidence of Preparation of Counting Aliquots}

Q. Were counting aliquots prepared?

A. SOPs for instrument calibration and operation were available and show the laboratory $\mathrm{QA} / \mathrm{QC}$ procedures included the preparation of counting aliquots.

Dates and Times of Processing and Separations

Q. Were logs kept of dates and times of sample preparation?

A. The team found no documentation to suggest the dates and times of sample preparation were logged. However, analysts' notes usually contain this information. Official laboratory records are not complete about the actual activity of a sample. Records received from the laboratories document the actual raw activity of the sample being analyzed, but some data are simply given as less than values, for example, $<10$ or $<20 \mu \mathrm{Ci} / \mathrm{mL}$. These few instances were always associated with difficult sample matrices such as sludge. Unfortunately, a sample cannot be classified as not containing radioactivity from DOE operations if the actual activity is not known.

SOPs Used for Analysis

Q. Were SOPs in place for analytical procedures and for standards preparation, background counting, etc.?

A. Copies of SOPs for analytical procedures for 1984 to 1991 were not available. Audit reports from the DOE-HQ Tiger Team show that requirements for periodic counter calibrations, background measurements, functional checks, and source checks and efficiency checks were not formalized and minimum intervals were not established.

Sample Counts

Q. Were sample counts made available?

A. Previous audit criteria did not suggest a lack of instrument operation and reporting sample counts on sample analysis sheets. It is assumed sample counts were available.

\section{Background Counts}

Q. Were background counts performed and at what interval?

A. Background counts were done per instrument calibration, but the procedures were not formalized. The interval for background counts was instrument dependent, based on the manufacturer's recommendations and not a referenced SOP.

\section{Dates and Times of All Counting}

Q. Were logs kept that showed the dates and times samples were counted?

A. As stated by employees interviewed, the time and date of analysis were kept on the instrument's microprocessor and were part of the entry commands to begin analysis. 


\section{Identification of Analysis}

Q. Was the type of analysis noted on the sample report?

A. The analysis type was noted on the sample result report.

Identification of Counters Used

Q. Was the instrument identified on the sample report?

A. The instrument used to count radioactivity levels was not recorded on the sample reports made available.

\section{Analogous Data for Appropriate QC Samples}

Q. Was similar data provided for samples also available for the QC samples?

A. Methods for investigation, resolution, and documentation of anomalous measurements and QC sample data that exceed acceptance criteria were not formally documented.

\section{Calculated Results, Propagated Errors, Detection Limits}

Q. Were calculations and detection limits shown on the sample report and errors propagated to calculate uncertainties?

A. The sample reports reviewed show counting calculations, detection limits, and propagation of errors were documented.

\subsection{WAA Administration}

After characterization at the point of generation, wastes go to a WAA for temporary storage. Use of WAAs has been described in the documentation since 1987. Before 1987, generators were instructed to arrange for waste pickup during the weekly waste run by Toxic Waste Control (the hazardous waste management organization in at the time) (Kahn 1985).

A WAA is an official accumulation area designed for the temporary storage of hazardous, radioactive, or mixed radioactive hazardous waste in drums or other containers between the time it is generated and the time it is picked up by HWM for transfer to the Building 612 or 693 yard for later disposal. The programmatic organization that generates waste is responsible for organization, construction, and maintenance of a WAA for the waste it generates. The waste generating organization appoints an individual as the WAA administrator, who is responsible for all activities in the organization's WAA (LLNL 1989b).

The waste generating organization has appointed the WAA administrator as the individual responsible for overall maintenance of a WAA and for operation of the WAA in a way that ensures proper handling of hazardous waste. The WAA administrator performs informal WAA inspections and maintains WAA records (including current contingency plans, an operations log, inspection logs, and summary reports of incidents) (LLNL 1989b and WAA Personnel Training 1992).

Other support personnel/organizations have responsibilities at a given WAA. They include: 

- HWM
- Generator
- Environmental Analyst
HWM is responsible for picking up waste from the WAAs and later treatment or packaging and disposal of waste. HWM helps in training other WAA personnel in their areas of responsibility.
Identify hazardous wastes produced by an operation or experiment, place all wastes in the WAA, notify the H\&S or HWM technician of the amount and type of waste taken to the WAA, and use correct packaging, labeling, and waste preparation procedures.
An Environmental Analyst (EA) is a member of the Guidance and Monitoring Division of the EPD. The EA is responsible for interpreting environmental requirements and providing compliance guidance. This includes review and interpretation of environmental regulations, approval of WAA construction design, identification of the amounts and types of wastes generated, providing guidelines for preparing and storing waste in the WAA, and training other WAA personnel about regulations and procedures of proper hazardous waste management. The EA also acts as the interface between the operating organization and regulators during inspections and approves and updates WAA contingency plans.

- H\&S Technician

- HWM Technician
The H\&S technician is a member of the HC Safety Team and aids organizations in managing hazardous waste, operating WAAs and in the construction of a WAA by gathering information on the types, amounts, and locations of wastes being generated. The $H \& S$ technician also inspects and approves containers for transport to HWM, surveys all radioactive waste containers, may perform weekly inspections of the WAA, and verify HWM has removed all waste from the WAA. The H\&S technician is an employee of the Hazards Control Department.

Some HWM technician responsibilities parallel those of the H\&S technicians. HWM technician responsibilities include gathering information on the types, amounts, and locations of wastes generated; inspect and approve containers for transport to HWM; and maintain a logbook of all activities related to the WAA. HWM technicians were available during the entire validation time but were used only on request before 1991 when they became more integrated into the generators process for properly characterizing, labeling, and shipping the waste.

WAA personnel are accountable for WAA operating records. These records include the operations log that contains a description, quantity, container type, and date of all waste received; dates of storage and the date of its transfer by HWM; and the location of each waste container in the WAA. WAA personnel must also maintain waste requisitions with available analysis information, inspection logs, the WAA Contingency Plan, and incident summary reports. 
Required inspections/surveys for each WAA include a daily walk-through to look for obvious in-use discrepancies. Weekly inspections are performed to look for malfunctions and deterioration of equipment and wastes/packaging, operator errors, and conditions that may lead to releases of

hazardous materials. Common weekly inspection items include posting and labeling of the WAA and the waste in the WAA, waste secondary containment adequacy, condition of emergency equipment, and appropriateness of waste segregation and packaging. Weekly inspection checklists (Figure 3-3) document the conduct and results of the inspection. The H\&S technician surveys and smears items entering and exiting WAAs that originated in an RMMA for radioactivity. Lastly, the Environmental Operations Group inspects WAAs internally biweekly for similar issues.

\subsubsection{Training}

H\&S technicians are trained to work as HP technicians, industrial hygiene (IH) technicians, and fire protection personnel. The H\&S technicians are required to go through several training courses provided by the EPD and included EP0006 "Hazardous Waste Generation and Certification," and EP0110 "Low Level Waste Generation and Certification." The H\&S technicians also receive training for taking swipe samples per guidance from the LLNL Swipe Manual.

Training for generators of wastes was limited before 1990. During 1990, HWM started training generators of wastes as described in the Hazardous Waste Management Plan (LLNL 1989) to allow them to make informed decisions for identification of wastes. Until this time, the generator had the "primary responsibility for identifying hazardous waste produced by an operation or experiment." The generator could contact the EA or H\&S technician to ensure waste preparation procedures used at the time met the environmental standards. The generator was responsible for placing all waste in the WAA and notifying the H\&S technicians of the amount and type of waste taken to the WAA However, the DOE-HQ Tiger Team has noted that HWM did not perform QC checks on the waste characterization and quantification performed by the generator.

3.4.1.1 HWM Technicians The HWM technician position became more involved with hazardous waste generators and management in about 1988. The duties of the HWM technician paralleled those of the H\&S technician and received similar training. The HWM technician is a member of the HWM Division. This technician is responsible for helping organizations in managing their hazardous waste and operating their WAAs.

3.4.1.2 WAA Administrators. Administrators of WAAs were operators or experimenters who worked with HC and HWM to site and construct the WAAs and were responsible for the waste until HWM delivered the waste to Building 612 for storage or packaging. WAA administrators had some training about RCRA hazardous waste, TSCA wastes, and radioactive wastes but evidence of waste minimization, waste characterization, and waste segregation was small. During the years 1990 and 1991, WAA administrators had much more thorough training.

\subsubsection{Surveying}

The H\&S technicians survey waste using smear samples and measure the surface contamination using field radiation equipment. Once surveyed, The H\&S technicians transfer custody of the waste to waste technicians who deal with all waste issues. Written procedures for surveying wastes were developed in 1988. Each H\&S technician group has a controlled copy of the standard operations manual. These manuals are specific to each team, and only one individual makes changes to the controlled copy. The H\&S technicians do not determine what area/room is an RMMA. On the HPs who classify and declassify RMMAs can make this determination. The H\&S technicians take the swipes or external radiation reading and give this information to the HP. 


\section{WASTE ACCUMULATION AREA}

Date

Time

\section{General}

Yes

No*

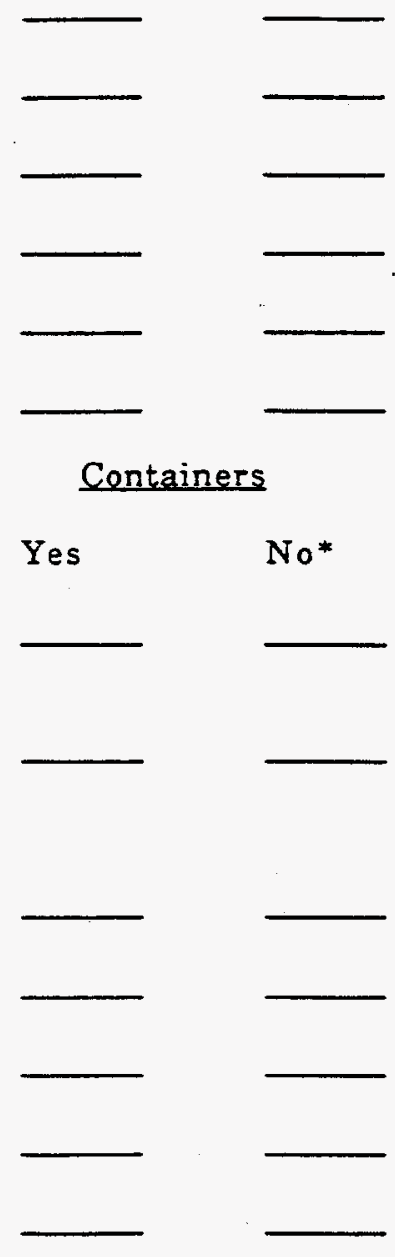

Bldg

Inspector

Area posted with appropriate hazard and cautionary signs.

Area free of spills.

Secondary containment basin free of liquid and debris.

Emergency equipment present and in operating condition.

Proper use of Hazardous Waste Management requisition form.

Current contingency plan posted.

All containers labeled with comoleted and dated Hazardous Waste Labels.

No waste containers present over the 90-day storage limit.

Note: If any waste containers are over the 90-day storage limit, contact your Environmental Analyst immediately.

Containers compatible with waste being stored.

Containers closed except when adding wastes.

Containers in good condition, free of leaks and deterioration.

Adequate separation of incompatible waste.

Ignitable waste isolated from sources of ignition and at least $50^{\circ}$

from property line (perimeter fence).

* Describe corrective action needed

Date corrective action completed:

88-188

Figure 3-3. Weekly inspection checklist. 


\subsection{Waste Tracking and Documentation}

For wastes generated by laboratory operations, generator knowledge was, and continues to be, the primary method for determination of whether a given waste is industrial, hazardous, radioactive, or mixed radioactive and hazardous waste. Using generator knowledge, supplemented by chemical and radiological analysis results if requested by the generator, the waste is placed in a WAA as either hazardous or radioactive or sent directly to Building 612 for handling by HWM. Before HWM will move or accept hazardous waste, an H-Req must be completed and signed by the waste generator. After receipt by HWM, the hazardous waste will be labpacked or repackaged as needed, manifested, and transported by a contractor to a TSDF appropriate for any given waste description. This general description of the current waste and documentation path for hazardous wastes has not been static during the time frame of this premoratorium data validation and has changed significantly since 1985 . Figures $3-4$ and 3-5 are diagrams illustrating the waste process flow during the validation period.

In 1985, the procedure required the generator to identify the waste (radioactive and hazardous) on a Toxic Waste Control Tag (Figure 3-6), which was superseded by a Hazardous Waste Management Tag but contained the same information. The generator then notified the Toxic Waste Control group for pickup, which used the information on the tag to decide the classification of waste, compatibility requirements, onsite treatment options, or to fill out the shipping manifest.

The Hazardous Waste Management Tags were used to track onsite waste streams between the period of 1979 to 1988 . Each tag contained an identification number and identified the waste generator, building number, date, onsite storage area, waste form, and sometimes contained radiological survey and analytical results when requested by the generator. The HWM tags did not reference the offsite shipping manifest, nor did they contain complete waste characterization information, so tracking offsite shipments back to generators between 1979 and 1988 would be extremely difficult. A VAX database was the primary link between the manifest and the HWM tags. Many the LLNL onsite and offsite shipping manifest records between 1984 and 1989 did not contain various pieces of the documentation required to track a sample from the generator to the TSDF.

H-Reqs were first used in 1988. The H-Reqs list the waste generator, building, WAA number, waste form, process generating waste, and quantity of waste (Figure 3-7). Information commonly attached to the H-Reqs included sample number and analytical results, Process Knowledge Generator Forms, and information on the document number of the Uniform Hazardous Waste Manifest derived from the tracking database. Documentation accompanying an individual $\mathrm{H}-$ Req may include any, all, or none of the items listed in Table 3-1.

Starting in 1991, the H-Req number was routinely recorded on the Uniform Hazardous Waste Manifest, and the waste stream could easily be tracked from the waste generator all the way to the offsite TSDF. Before 1991, while H-Reqs were used to track and transport wastes onsite at LLNL, they were not uniformly used as an inventory list attached to the manifest. From the start of H-Req use, they can be tracked to their shipping manifest by use of the electronic databases used for tracking waste at LLNL.

Many wastes generated at LLNL contained small volumes of laboratory wastes that were placed into laboratory packs once the wastes were received at Building 612 . The H-Reqs for the laboratory packs listed all the individual H-Reqs for waste placed into the lab pack. Lab packs were also cross-referenced using Laboratory Waste Disposal Requisitions (L-Reqs). 
Wastes known to contain radioactivity were tracked using Radioactive Waste Disposal Requisitions (R-Reqs). These requisition forms are similar to the H-Reqs, and tracking the waste stream from the waste generator to the waste disposition is possible.

A collection of several databases was in use for hazardous and radioactive waste management before 1988 and was called the VAX-INGRES Computer Database. Figure 3-8 is a schematic of the hazardous waste information database(s) used in 1987. The various databases used in $1987 \mathrm{had}$ different goals, contained different although overlapping information, and came into existence at various times before 1987. From 1988 through 1993, electronic tracking of hazardous waste was done with the Hazardous Waste Management Database (HWMDB). The Total Waste Management System (TWMS) superseded HWMDB in 1994. A map of the HWMDB database is presented in Figure 3-9. HWMDB data from 1988 to 1989 is in archive tables while data from 1994 on has been mapped to the TWIMS database and is, therefore, more readily available. HWMDB information was complete enough to track wastes from their origin to their disposition, i.e., the uniform hazardous waste manifest number used for shipment to a TSDF. The database contained little waste profile or manifest shipment information.

\subsection{HWM Repackaging and Manifesting}

After pickup from the WAAs, HWM delivers wastes to Building 514 for treatment or to another facility for repackaging, manifesting, and shipment. While in storage, the wastes are segregated, inspected, and surveyed. This monitoring includes surface radiation surveys for compliance with DOE Order 5400.

HWM maintains Uniform Hazardous Waste Manifests in a central locked storage room. As expected, the condition of the manifests and their content has improved significantly between 1985 and 1991. Early in the validation time frame, the manifests contain very little characterization data or information on the generator/generating process. From approximately 1988 to the present, the manifests frequently list profile sheet code numbers for wastes shipped on that particular manifest. These profiles are separate from, but are based on, those described earlier and contain a chemical description of the waste. LLNL or the TSDF generates them for the TSDF receiving the waste. HWM maintains copies of most profiles; they are also available from the TSDF that received the waste. 


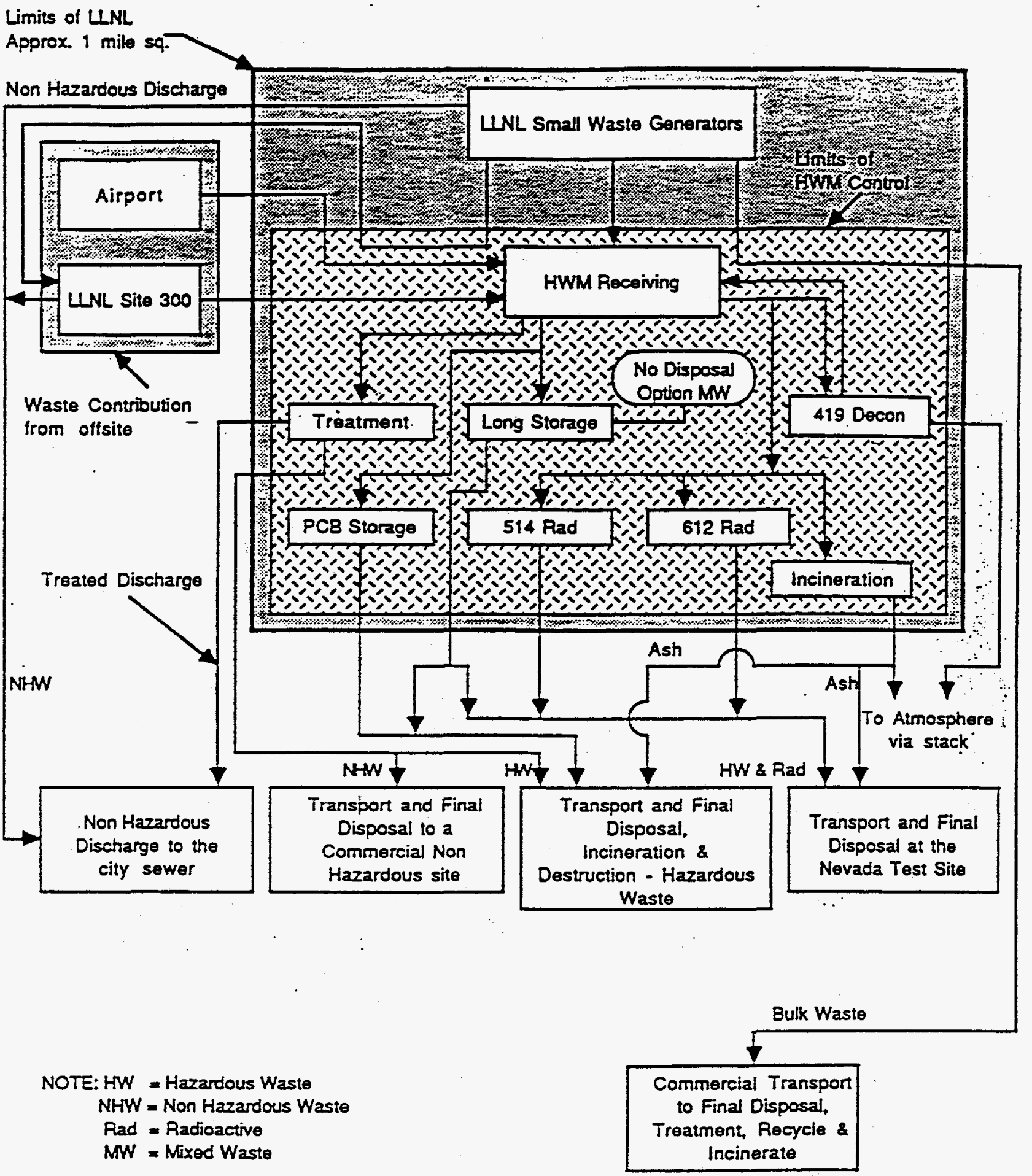

Figure 3-4. General LLNL Hazardous Waste Facility schematic. 


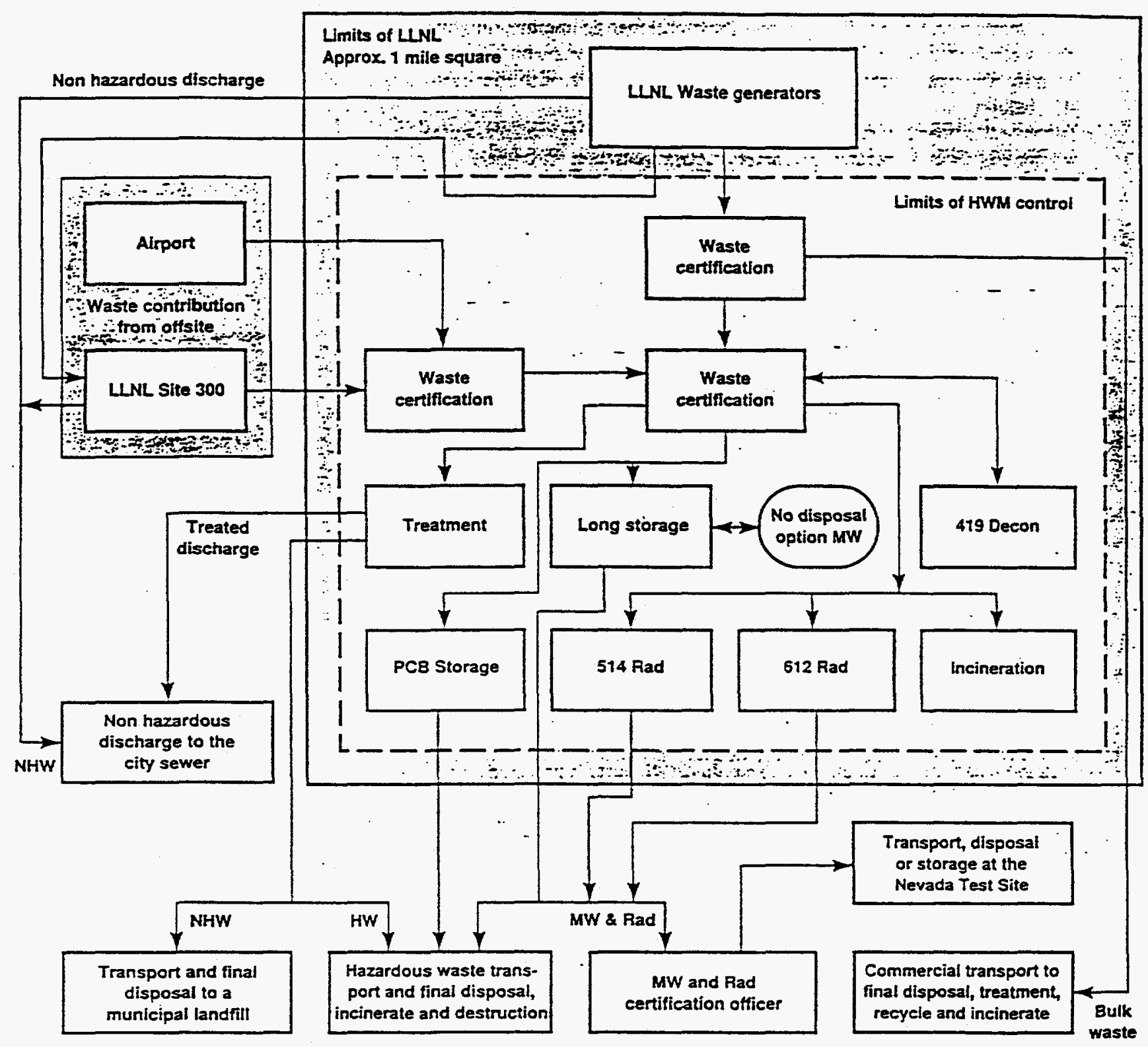

NOTE: HW = Hazardous waste $\quad$ NHW $=$ Non hazardous waste $\quad$ Rad $=$ Radioactive $\quad M W=$ Mixed waste

Figure 3-5. General LLNL waste process flow chart. 
SPECIAL

$\square$ HAZARDS

(Use Reverse)

TOXIC WASTE CONTROL TAG No. 009991

TO: NAME T.T.C.

BLDG.

REC SIG.

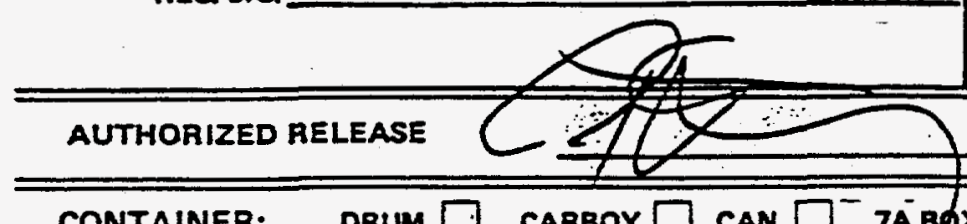

CONTAINER: $\quad$ DRUM $\square$ CARBOY $\square$ CAN $\square^{-} 7 A^{-B}$ COX $\square$ 1000 GAL TANK $\square$ OTHEA

WASTE FORM: DRY SOLIDXX $\square \quad$ LIOUंOOO $\square \quad$ SLLUDEE $\square$ GAS $\square$ FINE POWDER $\square$ PRESSURIZED VOLATILE LIOUUID
DATE:

FROM:

PROGRAMMATIC ORIGINATOR Biomed

NAME Pat Iewis

LIXD SITE $300 \square$ BLDG. 366 , RM.1P2 DATE: : signature Yat 
JUL H 006703 JUL HAZARDOUS WASTE DISPOSAL REQUISITION

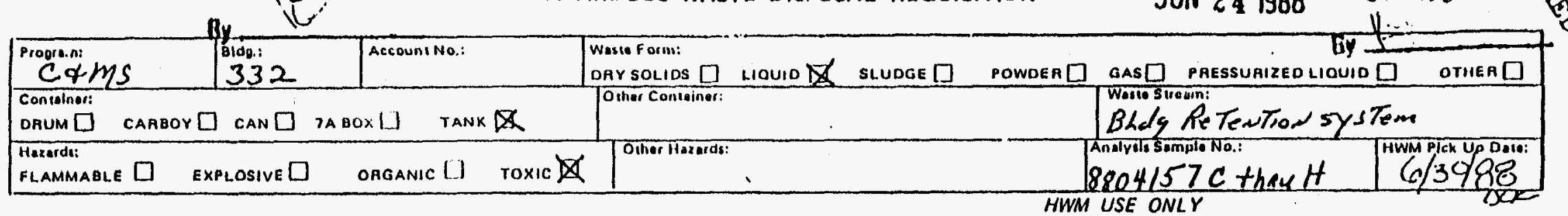

\begin{tabular}{|c|c|c|c|c|c|c|c|c|c|c|c|c|c|c|}
\hline ITEM & CHEMICAL/PHYSICAL DESCRIPTION & $\begin{array}{c}\text { WEIGH } \\
\text { Quendity }\end{array}$ & unles & Dor\# & $\begin{array}{c}\text { HAZARD } \\
\text { GLASS }\end{array}$ & $\begin{array}{l}\text { PAE } \\
\text { CUA }\end{array}$ & EPA\# & DOHS\# & TAEA & $\begin{array}{l}\text { ATMENT } \\
\text { Dato }\end{array}$ & & $\begin{array}{l}\text { LOCA. } \\
\text { TION } \\
\end{array}$ & $\begin{array}{c}\text { Dnum } \\
\# \\
\end{array}$ & $\begin{array}{l}\text { UISPO. } \\
\text { SITION }\end{array}$ \\
\hline 1 & $C_{4}$ & 3.06 & $m g / l$ & 9189 & $\begin{array}{c}\infty m-E \\
17\end{array}$ & $N$ & 0,07 & 132 & 501 & $7 / 6)$ & $y B R$ & G2E & 5858 & \\
\hline 2 & Cr & 20.2 & matle & & & & & & D81 & $7 / 21 / 88$ & $\beta R$ & 4 & & $925086^{\circ}$ \\
\hline 3 & Ni & 0.06 & mole & & & & & & & & & & & \\
\hline 4 & $Z_{N}$ & 4.02 & wole & & & & & & & & & & & \\
\hline 5 & & 0.14 & Hale & & & & & & & & & & & \\
\hline & $p H=7.6$ & & & & & & & & & & & & $1^{\circ}$ & \\
\hline & remaindes-unates & 99 & so & & & & & & & & & & & \\
\hline & the portable tank co & & & & & & & & & & & & & \\
\hline & apprex 700 galloras & & & & & & & & & & & & & \\
\hline & & & & & & & & & & & & & & \\
\hline & & & & & & & & & & & & & & \\
\hline & & & & & & & & & & & & & & \\
\hline & & & & & & & & & & & & & & \\
\hline & & & & & & & & & & & & & & \\
\hline & & & & & & & & & & & & & & \\
\hline
\end{tabular}

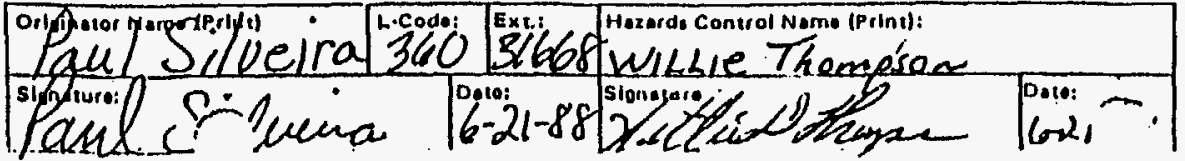

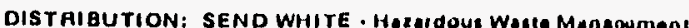
PLACE GAEEN . Contuinith KEEP BI UE - WUSIO OAlOL

Figure 3-7. Example Hazardous Waste Disposal Requisition. 
Table 3-1. Possible attachments to requisitions.

612 Requisition Update Form

90-day Waste Acceptance

Addendum

Analytical Request Form

Analytical Results

Hazardous Req Screen Dump

Hold for Pending Analysis

Hold for Verification

HWM Division Waste Embargo Shipping Authorization

HWM Overpack Discrepancy Form

HWM Requisition/Label Discrepancy Form

HWM Sample Custody Record

HWM Swipe Raw Data

Lab Pack Certification

Lab Pack Screen Dump

Land Disposal Restriction Notification Form

LLNL Radiological Survey Log Sheet

Manifest Records

Moratorium/Non-moratorium Waste Item Declaration

Packing List

Rad Screening Form

Radio. Screening Form

RCO Problem Form

Release From Pending Analysis

Req. Front

Request for EAS Sampling

Review of Radiochemical Data

RMMA/Non-RMMA Waste Item Declaration

Roll-Off Bin

RSDR

Contamination (EAS 306-1)

Swipe Results

Unlabpacked Update Form

USPCI Lad Ticket

Verification Failure

Verification Release

Waste Acceptance Request

Waste Run Inventory

WIS History 


\subsection{Treatment, Storage, and Disposal Facilities}

Hazardous and radioactive waste at the LLNL is treated onsite and treated and disposed at offsite TSDFs. If the level of contaminants in wastewater is below acceptance limits, the material is released to the sanitary sewer. The sewer limits for radioactivity are $5 \times 10^{-3} \mu \mathrm{Ci} / \mathrm{mL}$ for tritium, $3 \times 10^{-7} \mu \mathrm{Ci} / \mathrm{mL}$ for alpha, and $3 \times 10^{-6} \mu \mathrm{Ci} / \mathrm{mL}$ for beta (Appendix $\mathrm{H}$, LLNL Hazardous Waste Management Plan). The LLNL sewer permit (LLNL 1985) contains sewer limits for other contaminants, such as metals and biological oxygen demand. Otherwise, the material is labeled, placed into portable tanks or carboys and taken to either Building 514 (Liquid Waste Treatment Facility) or Building 612 (Solid Waste Treatment Facility).

The discussion in Section 2 on the LLNL data submittal gives waste types shipped to offsite TSDFs, which we will not further discuss here. The LLNL currently treats waste at one (or more) of the following facilities: Building 514 facility, Building 612 facility, Building 693 facility, or Building 233 facility (RCRA 1994).

\subsubsection{Closed Treatment and Storage Facilities at LLNL}

Other hazardous and mixed waste management units at the LLNL main site have operated in the past. These waste management units and their status now are as follows:

- $\quad$ Building 419, Size Reduction Unit and Solidification Unit has ceased operations and will be closed. Size reduction operations, which formerly occurred in Building 419, are now conducted at Building 612 and 514 while solidification operations at Building 513 have supplanted the Building 419 solidification activities.

- Area 612-3, Drum/Container Storage Unit was certified closed in 1993. The operation of Building 693 Container Storage Unit has replaced the storage capacity eliminated by the closure of Area 612-3.

- During the time of interest for this data validation, LLNL also operated an incinerator in Building 624 and drum/container storage operation in Area 612-613. Solid and liquid materials containing trace quantities of tritium, C-14, P-32, and S-35 were incinerated. LLNL operated the incinerator under an interim status document issued by the Department of Health Services (DOHS). A "Part B" application was filed with the EPA for the incinerator, and a trial burn was conducted in 1988. Later, changes to the incinerator injection system were made and retesting of the incinerator was completed in 1989. However, it was decided not to restart the incinerator. The State of California certified it closed in 1993. 


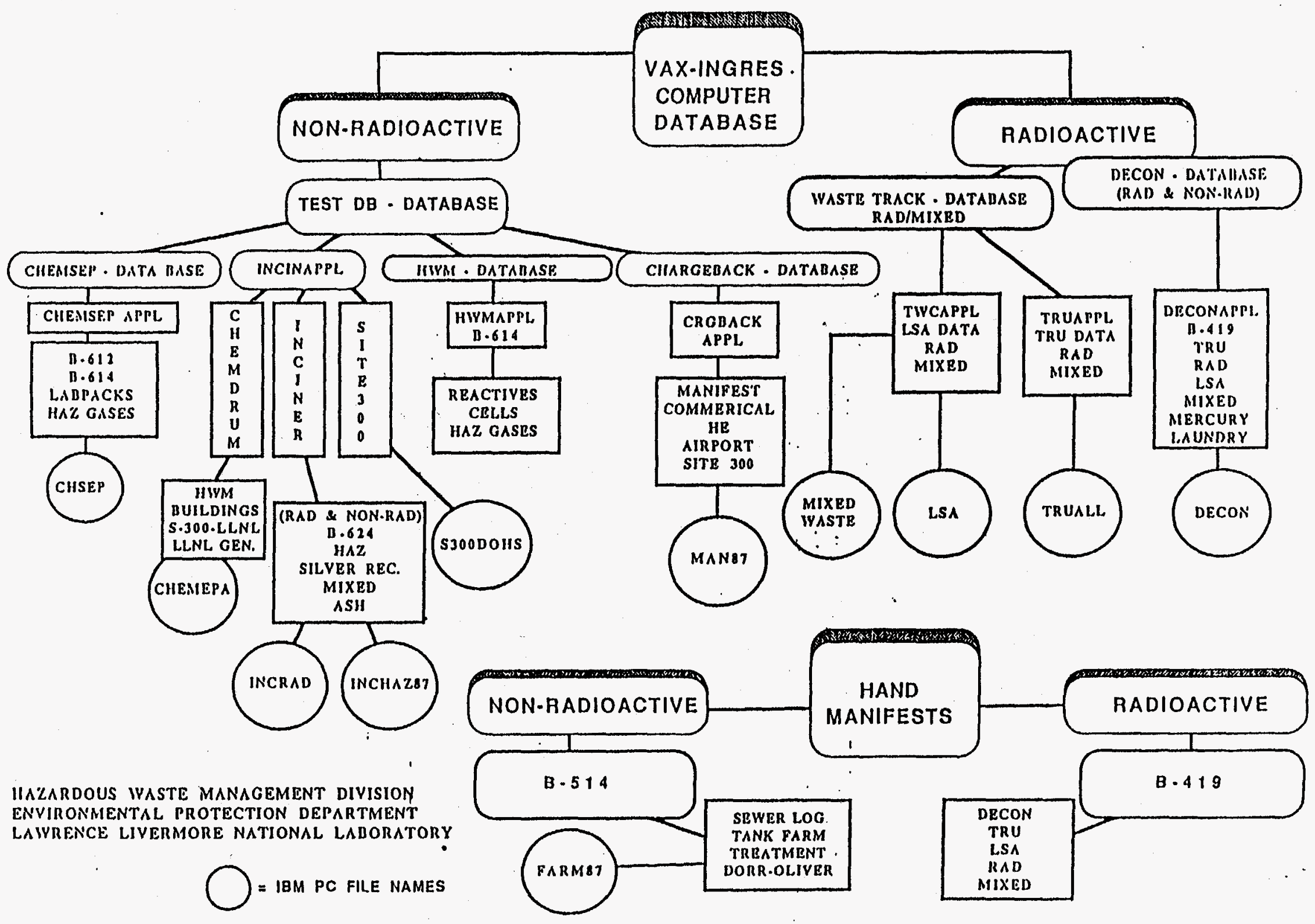

Figure 3-8. Hazardous Waste Information Database used in 1987. 


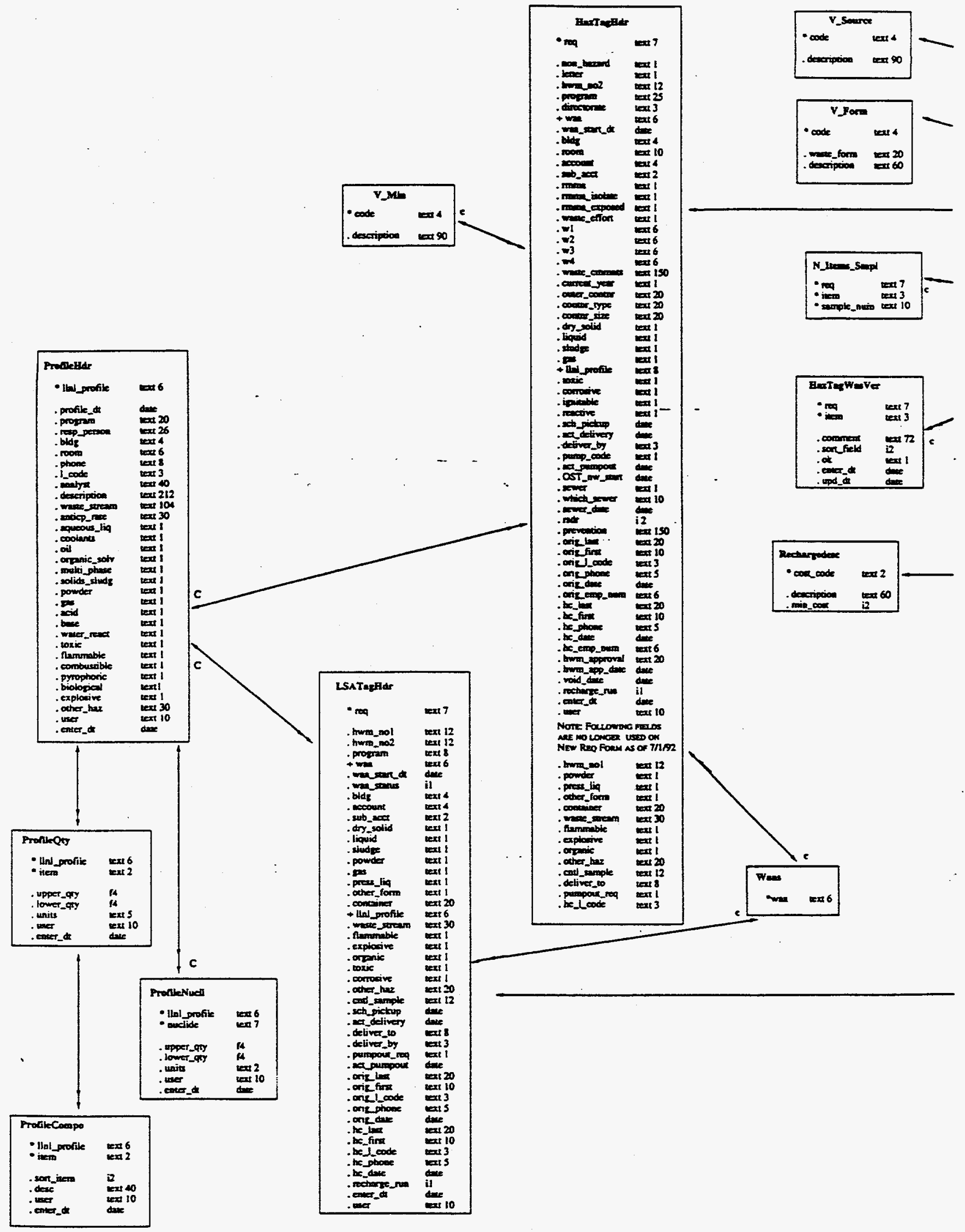

Figure 3-9. Hazardous Waste Information Database used in 1993. 


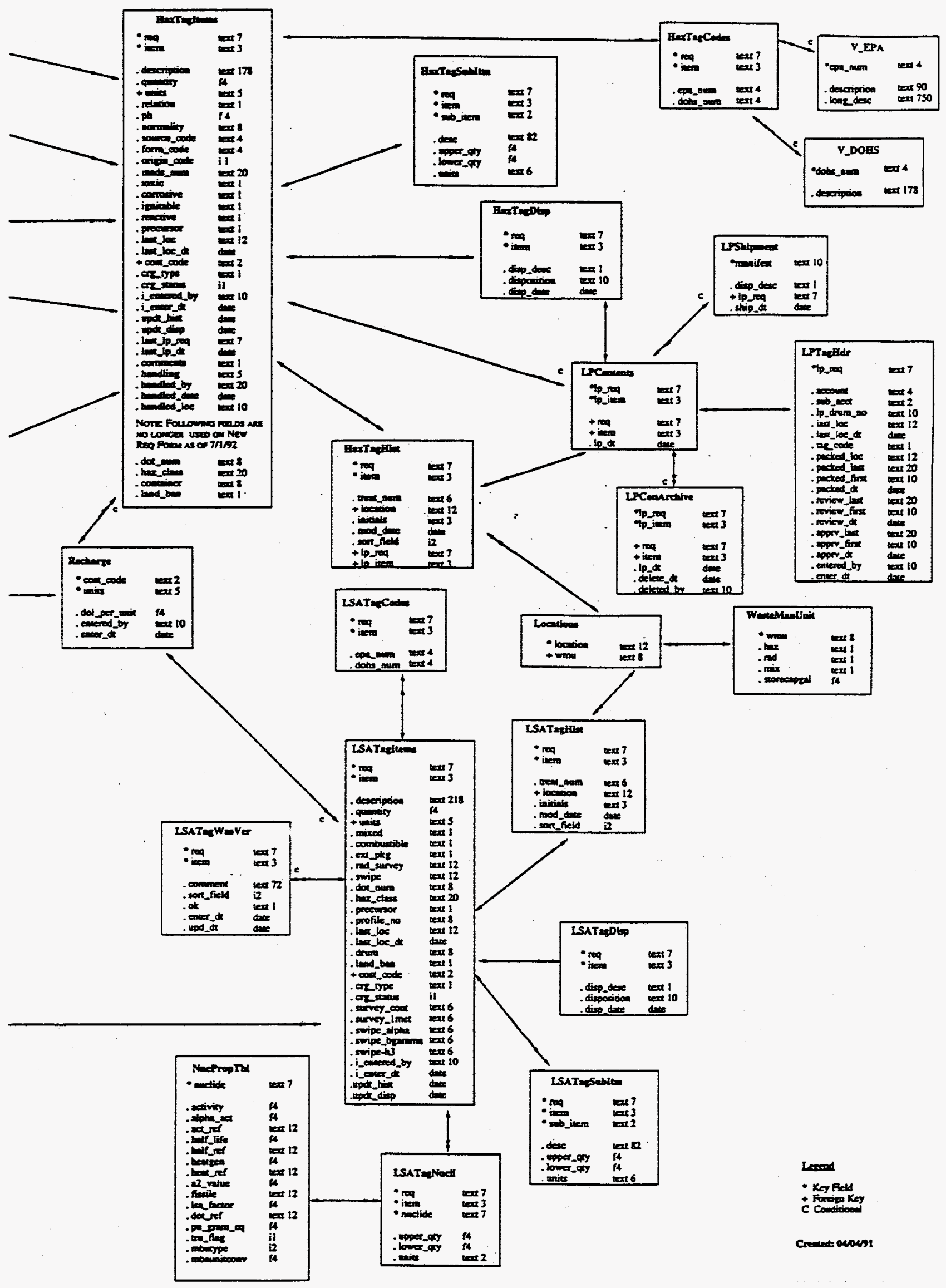

Figure 3-9. Cont'd. 


\subsubsection{Currently Operating Treatment Facilities}

LLNL now operates four HWM facilities at the Livermore site. These are the Area 514 facility, Area 612 facility, Building 233 facility, and Building 693 facility. The Areas 514 and 612 facilities contain treatment and storage units for hazardous and mixed wastes; the Building 233 and 693 facilities are container storage units for hazardous and mixed waste.

HWM facility operations at the LLNL are subject to Federal, State, regional, and local environmental requirements. Hazardous and mixed waste operations at the HWM facilities include the safe and proper handling, storage, treatment, packaging, and disposition of hazardous and mixed waste generated by the LLNL and affiliated generators. Depending on type, the waste may be chemically or physically treated or reclaimed. Onsite treatment methods include neutralization, flocculation, reduction, oxidation, precipitation, separation, filtration, solidification, silver recovery, size reduction, crushing, compaction, shredding, adsorption, blending, bulking, centrifugation, and evaporation. Wastes are stored in appropriate units onsite until shipped offsite for treatment or disposal.

The principal treatment technique for wastewater (Building 514) involves chemical precipitation followed by vacuum filtration through diatomaceous earth on a rotary drum filter. The filter cake is collected in plastic-lined drums and sent to Building 612. Other liquid waste with known contaminants may be treated by methods more suitable for that material. Liquid waste remaining after treatment is retreated or released to the sewer (if it is below prescribed guidelines). If the retreated water is still above guidelines, it is stored in a retention tank awaiting retreatment.

The following hazardous waste treatment system is currently used at Building 514: (LLNL

- Liquid waste retention tanks are at various laboratory facilities. The tanks may contain radioactive, corrosive, or other hazardous materials. HWM personnel routinely remove the contents of these tanks upon request from the waste generator or representative. Following the removal of the waste liquid from the tank, HWM either ships the material offsite for disposal, transports the material to the 514 Complex for treatment, or after getting signed approval from the EPD Guidance and Monitoring Division, discharges the material to the sanitary sewer. In each case, HWM personnel obtain a copy of an analysis of the tank contents before responding to a service request. The EPD EA provides guidance to the waste generator about the specific analysis to request from the analytical laboratory based on an assessment of the potential contaminants in the program's waste stream.

- Containerized and bulk liquid wastes are transferred into one of the six 1,800-gal. treatment tanks and chemically treated with hazardous materials. Each batch treatment is limited to approximately $1,500 \mathrm{gal}$. Following treatment, HWM personnel gather a representative sample of the treated liquid waste and analyze it at an approved analytical laboratory for $\mathrm{pH}$, metals, gross alpha and beta, tritium when appropriate, and other possible contaminants as necessary (dependent on the waste's Profile Sheet). The lab sends analytical results to the EPD Guidance and Monitoring Division for review. If the review shows the contents of a treatment tank are below established discharge limits, the Guidance and Monitoring Division issues a signed approval for releasing the liquid to the sanitary sewer.

- Photographic processing shops at Livermore and Site 300 produce waste liquids that 
contain recoverable amounts of silver in solution. After analysis the waste is sent to the HWM Silver Recovery Area where HWM Operations technicians operate equipment that removes the silver. The silver recovery operation consists of the following steps: pumping the contents of each waste container into an electroplating tank; electroplating the silver onto a cathode in the tank; pumping the solution from the electroplating tank into a filter feed tank; allowing the solution to gravity drain from the filter feed tank through a series of ion exchange filters into an effluent recovery drum; sampling the contents of each effluent recovery drum and submitting the sample for analysis; closing and labeling the drum for shipment to the Building 612 Complex for offsite shipment; retrieving the electroplated silver and the silverladen filter cartridges from the equipment; and transferring these items to Materials Management.

- The Dorr-Oliver unit (Building 514, Room 108) filters precipitate wastes from the tank farm chemical treatments. The operation consists of the following steps: creating a filter cake by coating a rotating drum with a slurry of diatomaceous earth; depositing the precipitate on the absorbent filter cake; capturing the filtrate in a retention tank; removing and packaging the spent, contaminated cake; obtaining a representative sample of the filtrate and submitting it for analysis; and, depending on the Guidance and Monitoring Division review, either discharging the filtrate to the sanitary sewer or retreating it.

Building 612 operations include waste receiving, segregation, lab packing, size reduction, storage, and drum crushing. Preparation and manifesting of waste shipments to commercial TSDFs occur at Building 612. The Building 693 and 233 facilities are also waste storage facilities. 


\section{WASTE ITEM VALIDATION}

A review of available documentation for radioanalytical results for hazardous wastes found, consistent with the original LLNL submittal, such data rarely exists. The vast majority of waste categorized as clean is based on generator knowledge. This places the responsibility on the generator to have significant knowledge of the waste stream process knowledge and its radioactive content. The nonreliance on analytical data also puts a border on the waste handling system, i.e., the procedures used and training of individuals assigned to use the procedures. As such, Section 3 of this report describes aspects of the waste handling process used at LLNL. This section will describe the validation process used and list the validation results.

\subsection{Validation Procedure}

The validation team examined H-Reqs that were in use between 1988 and the hazardous waste shipping moratorium in 1991. Tracking and documentation of waste disposition was greatly improved over that found from the period of 1984 to 1988 . During 1984 to 1988 Toxic Waste Control Tags tracked both radioactive and hazardous waste. A spot check of tags used for hazardous waste revealed few, if any, contained radioanalytical data.

The goal of the validation was to decide if LLNL had shipped DOE-added radioactivity to offsite TSDFs. Thus, the identification of wastes that had the greatest potential to contain radioactivity and the tracking of waste from radioanalytical data to the TSDF was a primary focus of the validation team. The focal point of tracking hazardous waste at the LLNL is the more than 70,000 H-Reqs archived by EPD for wastes generated from 1988 to 1991. More specifically, the validation team looked for wastes with radioanalytical results associated with H-Reqs that could then be tracked to an offsite shipment.

Since looking at all the H-Reqs for radioanalytical information was not possible, the evaluation team used three separate methods to examine a cross-section of the large number of available H-Reqs. The first method involved spot-checking H-Reqs from the records holding area to check if radioanalytical data existed, if the waste originated from an RMMA, or the waste was designated as non-radioactive based on generator knowledge. This first method served to familiarize the validation team with amounts and types of information available for different wastes. This method also included investigation of items encountered during conduct of the other two methods, which were outside the scope of the other two methods.

The second method was to select shipping Uniform Hazardous Waste Manifests containing wastes generated before the shipping moratorium in buildings containing RMMAs randomly. This consisted of using a random number generator to select offsite shipping manifests from the HWMDB with H-Reqs containing waste generated in buildings containing RMMAs (tracking waste from the manifest back to the generator). The team identified buildings assumed to have RMMAs for the manifest selections from tabulated information compiled by LLNL in 1991 showing which buildings then contained RMMAs and which had contained RMMAs in the previous five years (see Appendix C).

Manifests were randomly selected for examination using an EXCEL spreadsheet list of $\mathrm{H}$ Reqs (and their associated manifests) that contained wastes generated from buildings containing RMMAs between 1984 and 1991. Table 4-1 lists the selected manifests. Originally 25 H-Reqs were selected for investigation. As two of the rows selected corresponded to the same manifest, the team subsequently investigated only 24 . For a random sampling of a population, any sample greater than 
20 will give a picture of the entire population with a reasonable confidence. Five-digit numbers listed in Table 4-1 are a manifest's document number while the 8-digit numbers are the more commonly tracked State manifest document number. Those manifests selected with a 5-digit manifest document number was more difficult to track to the shipping manifest as most information is kept by the 8-digit State manifest document number.

Table 4-1. Randomly selected LLNL Uniform Hazardous Waste Manifests.

\begin{tabular}{lllll}
\hline 89930234 & 89413395 & AR461957 & 90895298 & 97096 \\
89930252 & 89413243 & AR461962 & 91760005 & 87250946 \\
89930254 & 89413247 & 90271799 & 91760105 & 87250956 \\
89930279 & AR145188 & 90271803 & 90157 & IL3243667 \\
89930586 & AR461921 & 90895294 & 89136 & \\
\hline
\end{tabular}

The third method used was to recognize some facilities, due to their purpose, had a higher likelihood of generating hazardous waste on which radioanalysis had been conducted. The team examined a sample of $\mathrm{H}$-Reqs for wastes generated or shipped from Building 332 (plutonium facility), Building 331 (tritium facility), Building 419 (decontamination facility), Building 514 (waste treatment facility), and Building 612 (storage and packaging facility).

This validation (all three methods) was done on a manifest and H-Req basis rather than by number of items or weight because a manifest may have one to hundreds of individual items weighing from ounces to thousands of pounds. For example, a manifest may be for a tank pumpout of 1,500 or more gallons of wastewater (one item) or for tens or hundreds of lab pack drums containing many individual packages. The definition of an item on a manifest may be a single lab pack drum; while for waste characterization, it may be the multiple packages inside the drum or the collection of packages containing identical material inside the drum.

The H-Reqs were checked for analytical data, generator process knowledge, waste stream information, and disposition/treatment of waste. The evaluation team reviewed analytical results to identify waste that possibly contained levels of radioactivity above the LLNL release criteria or above background levels. The sample or H-Req number may then be used to track the waste through the HWM tags or H-Reqs to the waste disposition. 


\subsection{Validation Results}

This section reports results of the portion of the validation that looked for radioanalytical data associated with waste on $\mathrm{H}$-Reqs and manifests. Appendix D is a summary of available information on the various $\mathrm{H}$-Regs examined, including radioanalytical data. Appendix $\mathrm{E}$ contains results of waste designation per the DOE postmoratorium definitions described in Section 2. While results of direct or swipe radiation surveys of the packaged waste (as required by DOE Order 5400.5) are rarely found in the archived documentation, it is believed these surveys were routinely conducted at the WAA or when in storage before offsite shipment. Using the three methods described in section 4.1, the validation team investigated about $700 \mathrm{H}$-reqs.

\subsubsection{Spot Check Results}

The spot-checked H-Reqs were selected either because they contained radioanalysis data, as examples of commonly found H-Reqs, or were somehow atypical of most of the H-Reqs investigated. Of the 85 spot-checked H-Reqs, 52 contained sample radioanalytical analysis results. Thirty-six of the 52 with analysis results had concentrations in excess of one of the LLNL release criteria.

\subsubsection{Random Manifest Results}

Of these randomly selected manifests, four included $\mathrm{H}$-Reqs with radioanalytical results while three listed package swipe or direct survey results. All four items (and manifests) that included radioanalytical datashowed radioactivity in excess of either the LLNL release criteria cited in the data submittal or had a radioanalytical LOS significantly greater than the criteria. The data in these manifests came from four of the more than $330 \mathrm{H}$-Reqs making up the randomly selected manifests. Waste tracked through the LLNL waste handling system does not require all items on a H-Req go to a TSDF on a single manifest. Waste items on a single H-Req may be shipped on multiple manifests. Many H-Reqs describing waste on these random manifests could not be checked for radioanalytical data as they were being microfiched. All other wastes on H-Reqs checked because of the random manifest selection are considered clean or likely clean.

Several H-Reqs (H028227 to H028235) were shipped on manifest 89930254, which available documentation shows contained sludge from drain lines in Building 222 and 227 (chemistry). A sample of the sludge contained elevated levels of mercury, chromium, lead, nickel, and gross alpha and gross beta concentrations of $5 \times 10^{-6}$ and $1.5 \times 10^{-5} \mu \mathrm{Ci} / \mathrm{g}$, respectively. These gross radioactivity levels are slightly in excess of the sludge release criteria of $1 \times 10^{-6} \mu \mathrm{Ci} / \mathrm{g}$ gross alpha and $3 \times 10^{-6} \mu \mathrm{Ci} / \mathrm{g}$ gross beta. Sludge is often a difficult matrix to analyze, however, the radioanalytical results had reasonable detection limits and the release criteria reflect potential matrix specific analysis problems.

Strip tank sediment waste from Building 322 (the plating shop) described on H045030 was shipped on manifest AR461921. Radioanalytical results show gross beta concentrations of $4.5 \times 10^{-6} \mu \mathrm{Ci} / \mathrm{g}$, slightly above the LLNL release criteria for sludges of $3 \times 10^{-6} \mu \mathrm{Ci} / \mathrm{g}$ and must be considered likely radioactive. While this is a difficult matrix to analyze, as the results were in excess of the criteria, an additional alternate analysis technique could have been employed to find out the origin of the activity.

Manifest 89413395 contained caustic etch bath from Building 322 (H-Req 14042). This aqueous solution had gross alpha beta analysis results of $<2.7 \times 10^{-7} \mu \mathrm{Ci} / \mathrm{ml}(270 \mathrm{pCi} / \mathrm{L} \mathrm{MDA})$ and $<2.4 \times 10^{-7} \mu \mathrm{Ci} / \mathrm{ml}(240 \mathrm{pCi} / \mathrm{L} \mathrm{MDA})$, respectively, an order of magnitude greater than the $10^{-8}$ release criteria for these analytes. While the plating shop probably would not contain significant 
amounts of radioactivity, the presence of radioanalytical data would suggest the generator had some idea that the solution was potentially contaminated. Under these circumstances further analysis could have decided if the contamination levels were below the release criteria. Similarly, manifest 90271803 contained a small amount of pump oil from Building 251 (nuclear chemistry) with a gross beta content of $2.5 \times 10^{-6} \mu \mathrm{Ci} / \mathrm{ml}$. This is just slightly above the LOS release criterion for oil of $2 \times$ $10^{-6} \mu \mathrm{Ci} / \mathrm{ml}$.

All four sets of the data found for wastes in the randomly selected manifests had results greater than the criteria listed above for gross alpha or beta analysis. These four H-Reqs with data were $1.2 \%$ of the number of $\mathrm{H}$-Reqs represented on the 24 manifests, or less than $1 \%$ on an item basis. Whether this shows the amount of waste containing DOE-added radioactivity cannot be determined. These manifests documented wastes from buildings containing RMMAs, potentially biasing the results high for the LLNL as a whole. However, the fact that all those items containing data exceeded the release criteria may suggest that wastes were not analyzed often enough to ensure generator knowledge was adequate to be sure LLNL shipped no DOE-added radioactivity offsite. This is especially uncertain for items from the same location or with the same waste description as those items for which data could be found.

\subsubsection{Biased H-Req Sample Results}

Less than $5 \%$ of the approximately 700 biased $\mathrm{H}$-Reqs examined contained radioanalytical data. Of the 32 that did, 17 exhibited gross alpha, gross beta, or tritium levels in excess of the LLNL release criteria for the particular waste matrix. Most of these did not appear to contain significant amounts of activity. 


\section{VALIDATION SUMMARY}

The primary purpose of the LLNL offsite hazardous waste shipment data validation project is to examine shipment records from 1984 through 1991 to decide whether items in offsite waste shipments were properly categorized according to the DOE-HQ moratorium waste category definitions. These definitions were not in place at the time the waste was generated but are based on whether activity was added to the bulk or volume of the waste through DOE operations.

This validation examined two facets of waste generation and shipment at LLNL. The first was an examination of procedures used at LLNL to decide if a waste was radioactive and how hazardous wastes were handled from the point of generation to the final disposal. The second portion of the validation was a survey of documentation on hazardous wastes generated before the moratorium, especially wastes for which radioanalytical data was available, to decide if LLNL properly categorized wastes.

Results of the analysis of LLNL procedures in place at the time show that, consistent with the LLNL data moratorium data submittal, generator knowledge was almost exclusively used to decide whether a waste was radioactive. Available procedures discussed how to handle radioactive waste or hazardous waste, but did not describe how to decide if a waste was radioactive.

Consistent with DOE-HQ Tiger Team findings, the validation team noted that for most of the validation period, consistent procedures for when and how a sample should be taken were not in place. Also, coordination between analysts and waste generators on how to read radioanalytical results (when obtained) was ineffectual. Additionally, the reliance on gross alpha and gross beta measurements was excessive (the team identified no spectrometric analysis results for potentially contaminated hazardous waste).

Tracking documentation improved significantly over the validation period. The use of $\mathrm{H}$ Reqs starting in 1988 and their progressively more common usage improved the tracking of wastes at LLNL substantially. The use of H-Req numbers as a register of wastes shipped on manifests late in the validation period extended this tracking improvement. Database tracking of waste was present for the entire validation period and its usability increased as time went on.

Procedures for when onsite treatment (Building 514) is appropriate were incomplete for the validation period as they can be construed to allow disposal by dilution to the sanitary sewer of wastes that contain activity levels that otherwise would not allow them to be disposed as hazardous waste. Single systems treated radioactive, hazardous, or mixed waste simultaneously or consecutively. Effluents were released to the municipal sewer system when they met discharge gross alpha/beta limits higher than the LLNL limits in place for hazardous wastes to be shipped to commercial TSDFs. Wastes were passed through the treatment system multiple times until they met these gross alpha/beta limits. Identical effluents from individual batches passed through the treatment systems were disposed on a batch basis as radioactive, hazardous, or industrial (sewerable) waste.

The investigation of $\mathrm{H}$-Reqs showed that, as stated in the LLNL data submittal, radioanalytical data for hazardous wastes rarely exist. The team chose to examine H-Reqs that were more likely to contain radioanalytical data. When such data were found, results were compared with LLNL LOS/background release criteria limits used from 1989 through 1991 described in the LLNL data submittal. Less than $5 \%$ of the $\mathrm{H}$-Reqs examined for waste generated at buildings containing RMMAs contained radioanalytical data. About half the radioanalytical data attached to $\mathrm{H}$-Reqs had gross alpha, gross beta, or tritium levels in excess of the criteria, generally by a small amount. In agreement with the LLNL data submittal, this shows that a very small percentage $(<1 \%)$ of hazardous waste generated at the LLNL main site can be shown to contain DOE-added radioactivity. 


\section{REFERENCES}

Adams, Sheryl D., Science Applications International Corporation, letter to Dan Hoyt, Lawrence Livermore National Laboratory, "DOE Order 5400.5 Additions to LLNL Waste Management Plan (WMP)," September 26, 1990.

Crawford, Richard, Lawrence Livermore National Laboratory, letter to Mike Rohe, EG\&G Idaho, "Comments on Lawrence Livermore National Laboratory Data Regarding Offsite Shipments of Hazardous Wastes," May 27, 1992.

DOE Office of Environmental Guidance (EH-23), Safe Drinking Water Act, ORNL/M-1899, Revision 6, September 15, 1992.

DOE, Environmental Restoration and Waste Management Office of Waste Operations (EM-30), Performance Objective for Certification of Non-Radioactive Hazardous Waste, Draft, April 6, 1993.

Duffy, Leo P., "Data Requirements on Past Shipments of Hazardous/Toxic Wastes Potentially Contaminated with Radioactivity," DOE Internal Memorandum, August 26, 1991.

Edwards, Chip, Radiation Analytical Sciences, memo to Howard Hall, "RAS Assessment Number 94-AST-03 Records Control," October 26, 1994.

Energy \& Technology Review, The State of the Laboratory, January/February 1994.

Environmental Protection Agency, Guidance for Data Useability in Risk Assessment (Part B), Publication 9285.7-09B, PB92-963362, May 1992.

ES\&H Review Team Findings, ES\&H89-06, November 29, 1989.

Hazardous Waste Shipment Data Validation Work Scope, Final Comment Memorandum.

Kahn, James S., Lawrence Livermore National Laboratory, letter to Dwight Hoenig, Department of Health Services, "Transmittal of LLNL Operation Plan, EPA ID No. CA2890012584," March 27,1985 .

Lawrence Livermore National Laboratory, Ordinance No. 1134, Relating to Control and Operation of the Sewage Collection and Treatment System, April 1985.

Lawrence Livermore National Laboratory, Environmental Protection Guidance and Monitoring Series, Guidelines for Waste Accumulation Areas, UCAR-10192, March 1987.

Lawrence Livermore National Laboratory, Environmental Protection, Preparation Guide for Generators of Hazardous Chemicals and Radioactive Waste at LLNL, March 1987.

Lawrence Livermore National Laboratory, Environmental Protection Hazardous Waste Management Division, Hazardous Waste Management Plan, UCAR 10264, September 1989.

Lawrence Livermore National Laboratory, Environmental Protection Guidance and Monitoring Division, Guidelines for Waste Accumulation Areas, UCAR 10192, Rev. 1, March 1989. 
Lawrence Livermore National Laboratory, DOE-HQ Tiger Team Report, 1990.

Lawrence Livermore National Laboratory, Environmental Protection Department, Hazardous Waste Management Division, The 1991 Hazardous Waste Report - Mainsite (Biennial Report), April 1991.

Lawrence Livermore National Laboratory, Environmental Protection Department, Technical Implementing Procedure, "Sample Receipt, Handling, and Disposal in the HWRL," TIPRAS-110, November 11, 1993.

Nakahara, Dan, DOE-SF, memo to Lisa Page, EG\&G-ID, "Data Request on Past Shipments of Waste," January 28, 1992.

RCRA Part B Permit Application, Vol. 1, Part IV, March 1994.

Steiner, Steve, Lawrence Livermore National Laboratory, memo to Keith Gilbert, "HWM Training," December 21, 1989.

Science Applications International Corporation, Waste Sampling Strategy Plan for Verification of Waste at the Lawrence Livermore National Laboratory, UCRL-CR-105452, December 1990.

Waste Accumulation Area Personnel Training, Lesson 2, "Waste Handling Practices at the Waste Accumulation Area (WAA)," EP0053, July 6, 1992.

University of California, Lawrence Livermore National Laboratory, 1993 Report for the Regents, UCAR-10223-93, April 1994.

University of California, Lawrence Livermore National Laboratory, Framing the Laboratory's Future, UCRL-AR-117362, June 1994. 


\section{APPENDIX A}

\section{LLNL TSDF Flowcharts}


APPROPRIATE TECHNOLOGIES II

Wasie Stream: LABPACKS

- ranseorters: MP Vacuum Truck Service

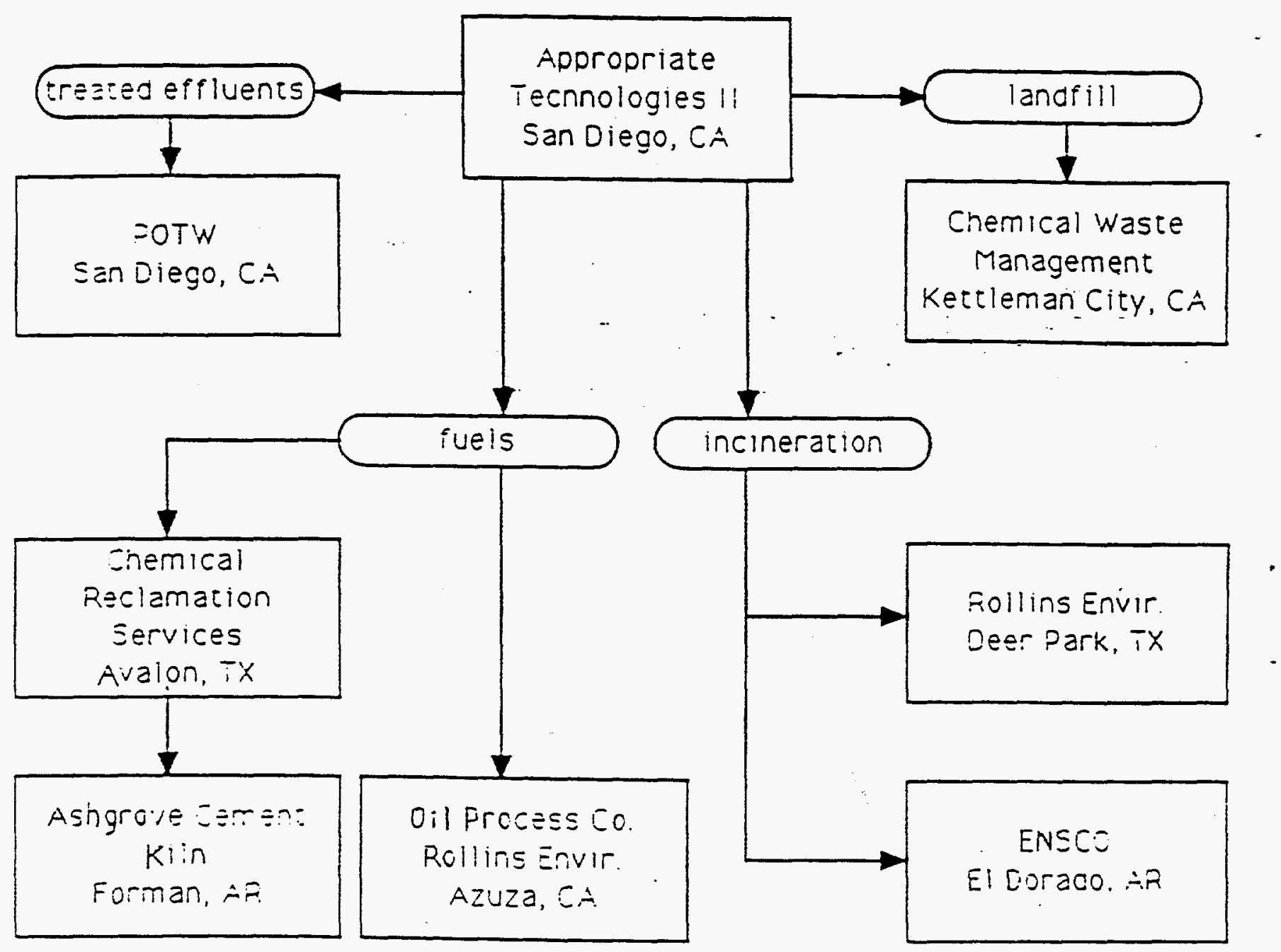


ङARON-BLAKESLEE

vaste Streams: Freon TF

-ransporters: Baron-Elakeslee

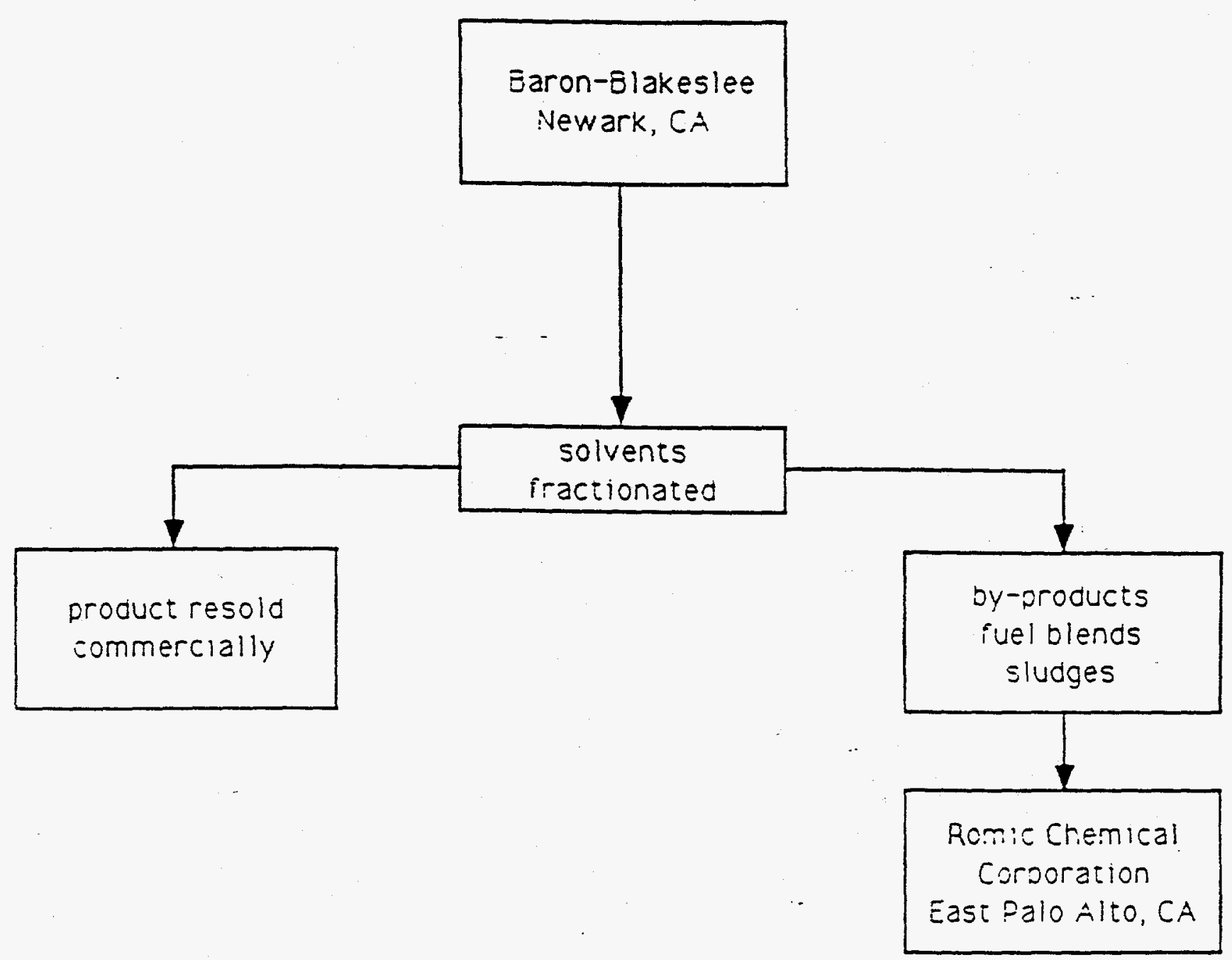




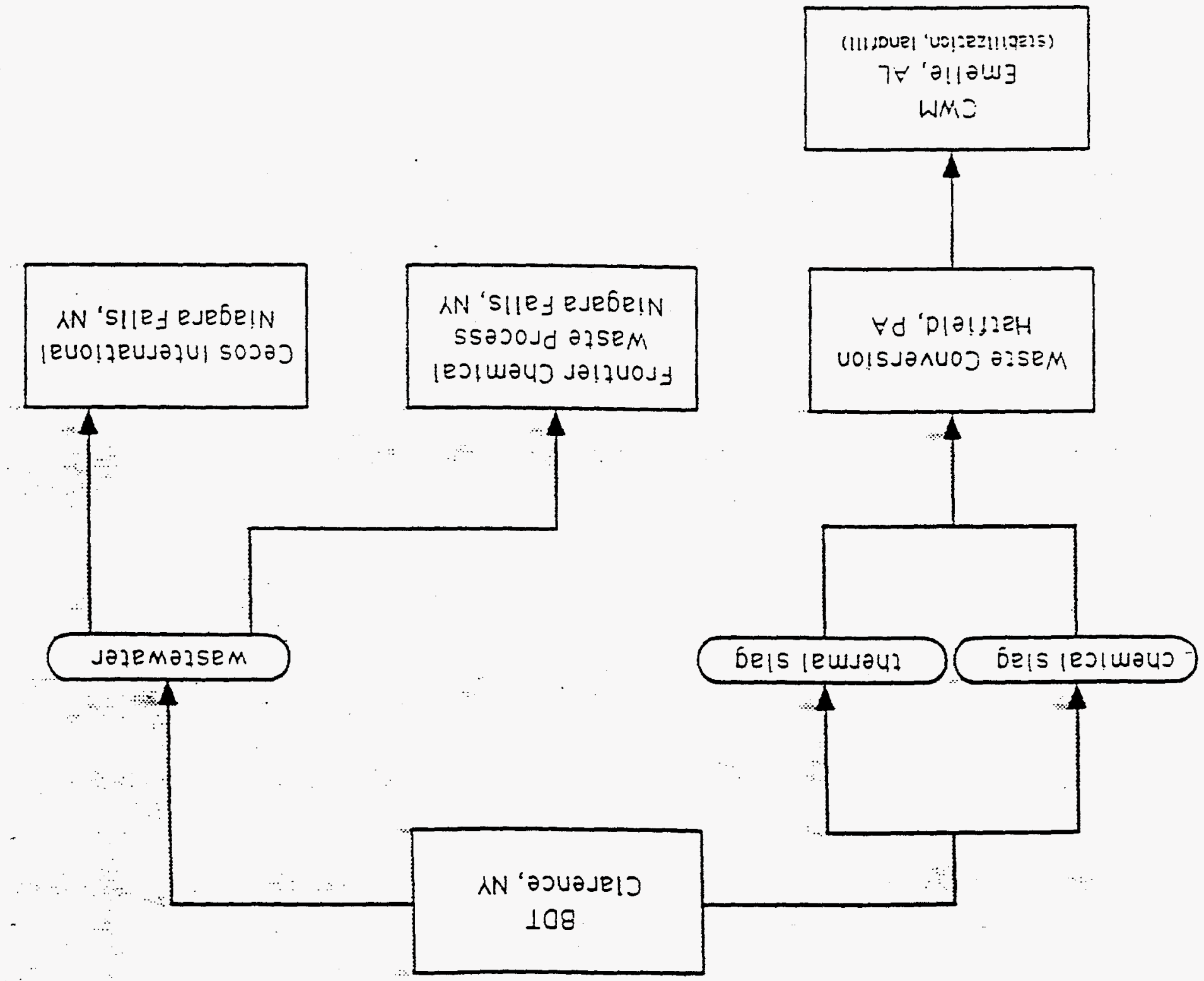

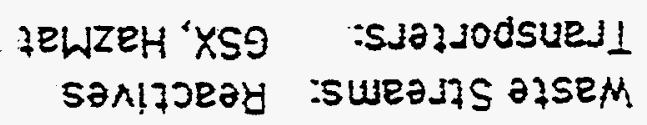


OREW RESOURCES

Waste Streams: Silver-bearing Filter Cartridges

Transporters:.. LLNL.

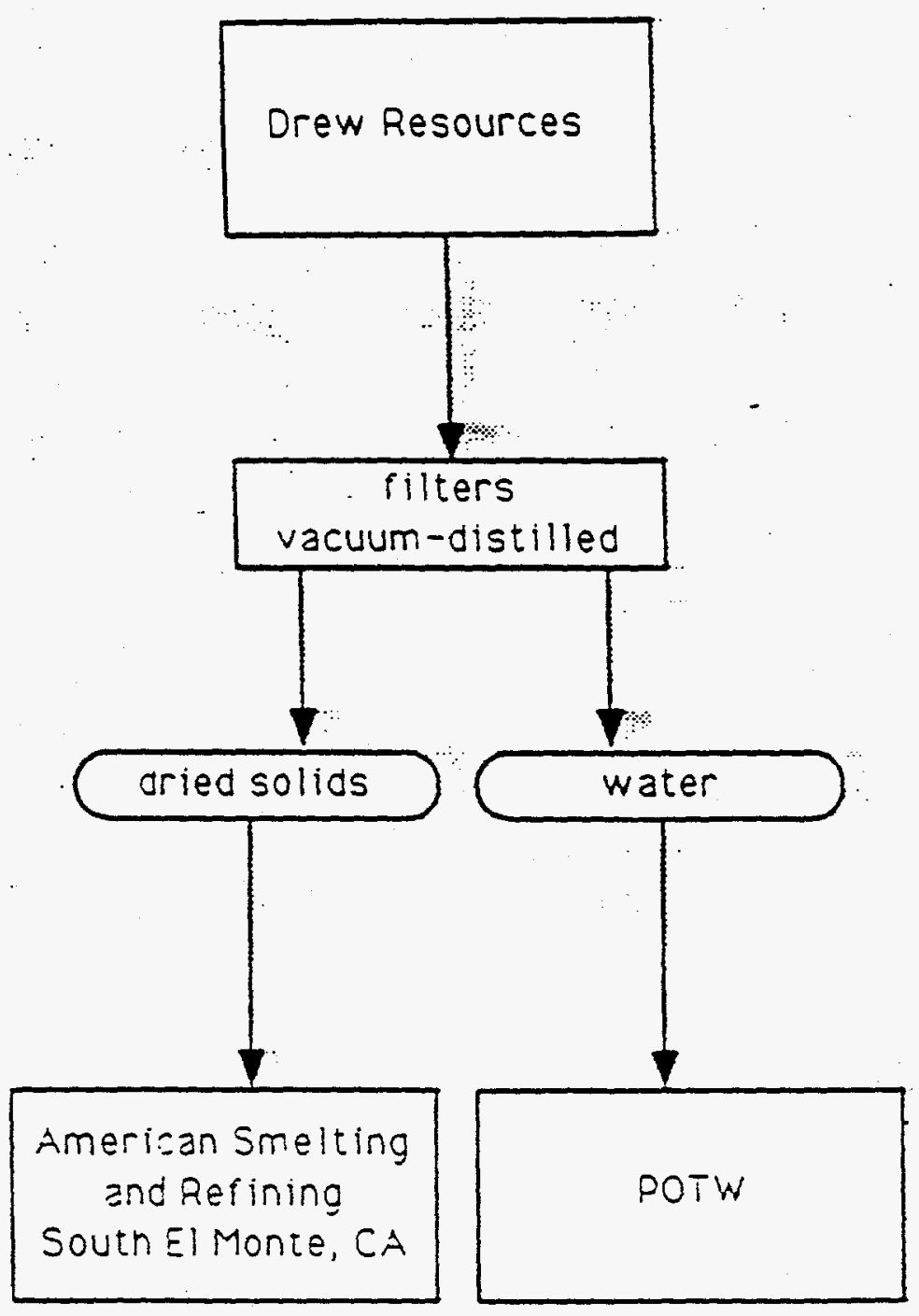




\section{ENGLEHARD INDUSTRIES}

Naste Streams: Gold, Gold Cyanide, and Gold Acid Solutions

iransporters: GSX, Englehard

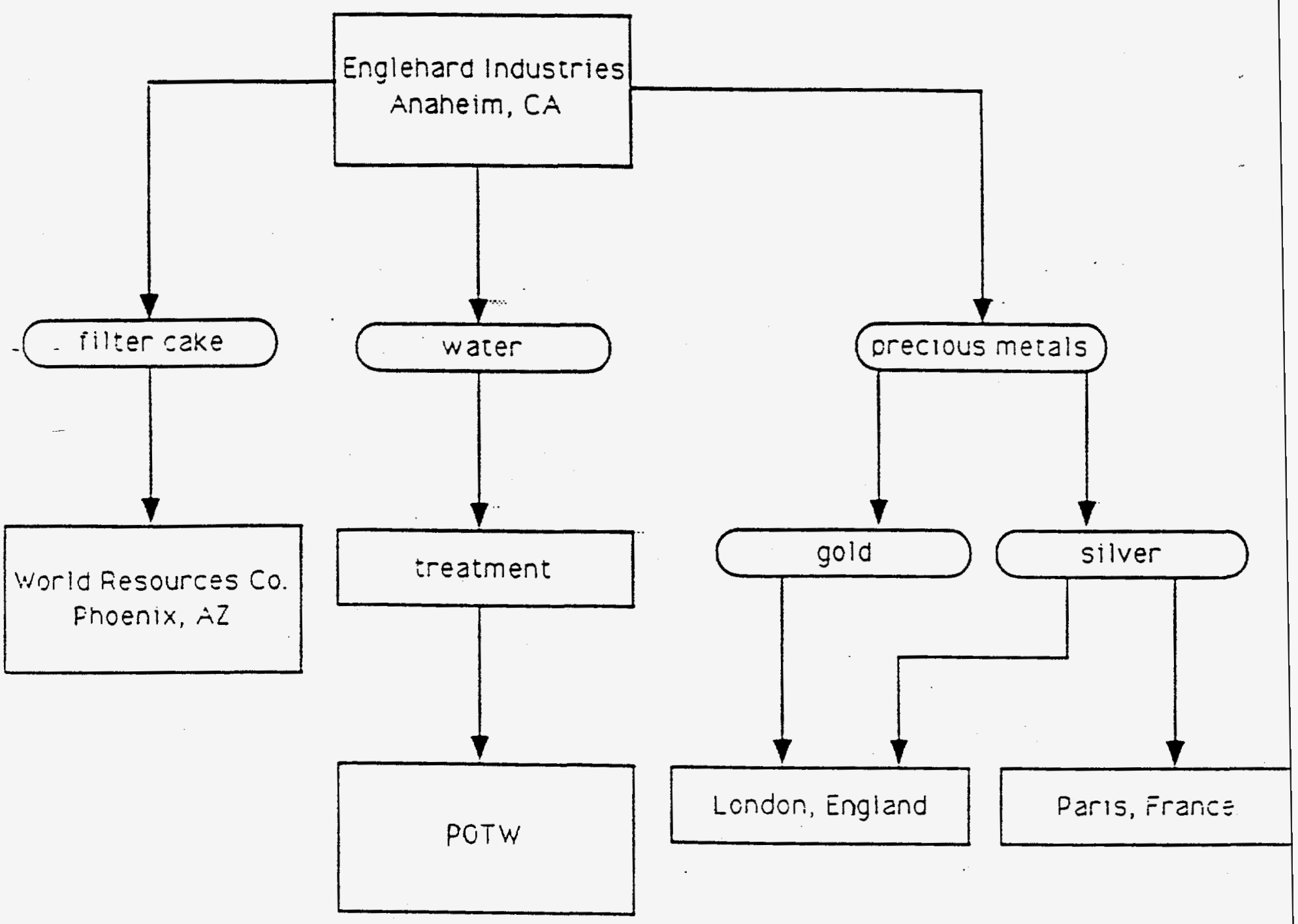


'Naste Streams: Lab:Packs, Organics, PCBs

iransporters.. GSX, Tri-State Motor Transit

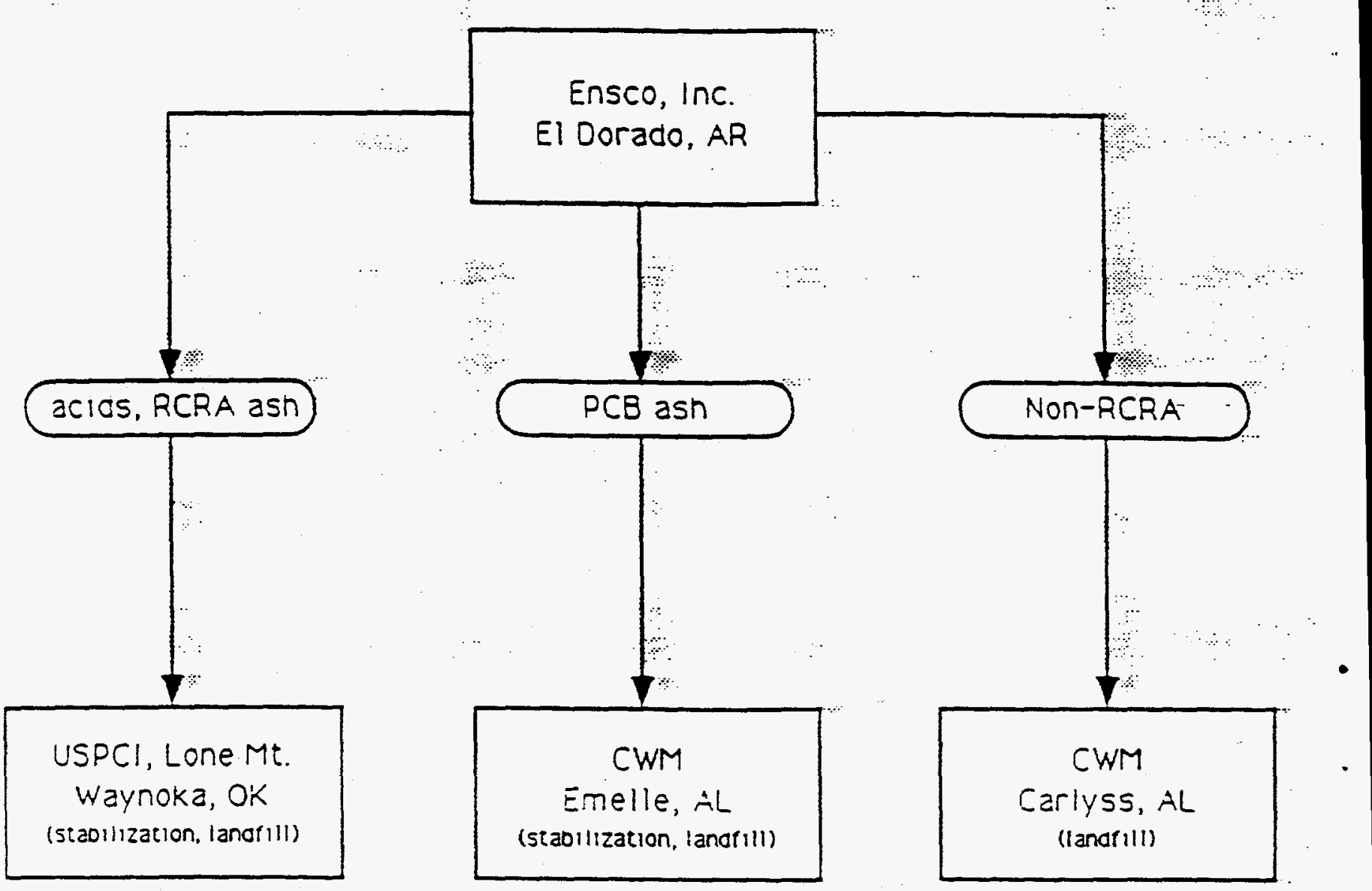


Waste Streams: Photocnemicals, acids, bases, cyanides

-iansporiers: GSX, Exceltrans

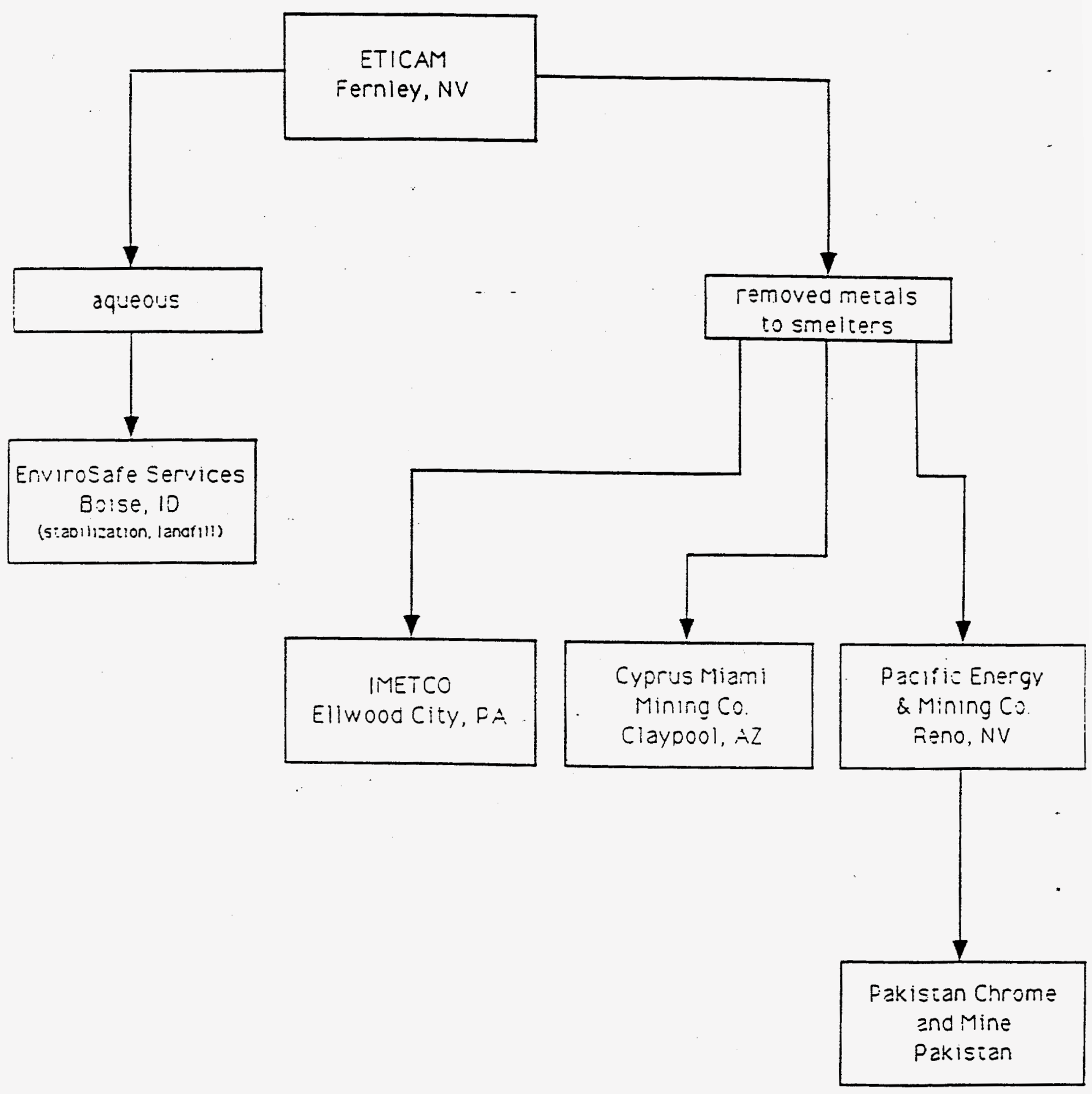


waste Streams: jil

iransporters: Evergreen Oil

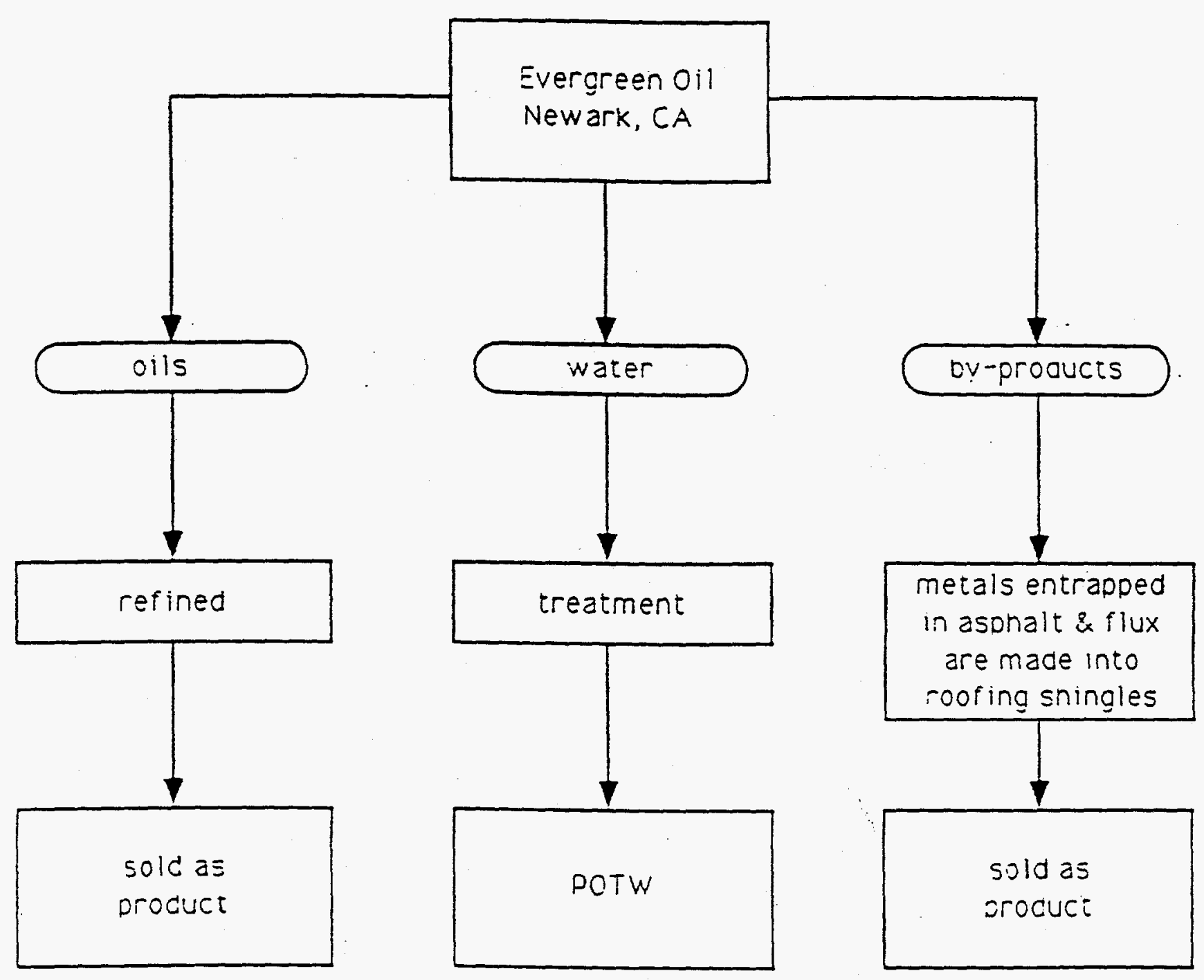


GSX, Greenbrier

Waste Streams: Lab Packs, Organics, Acids, Bases, and Reactives Transporters: . GSX

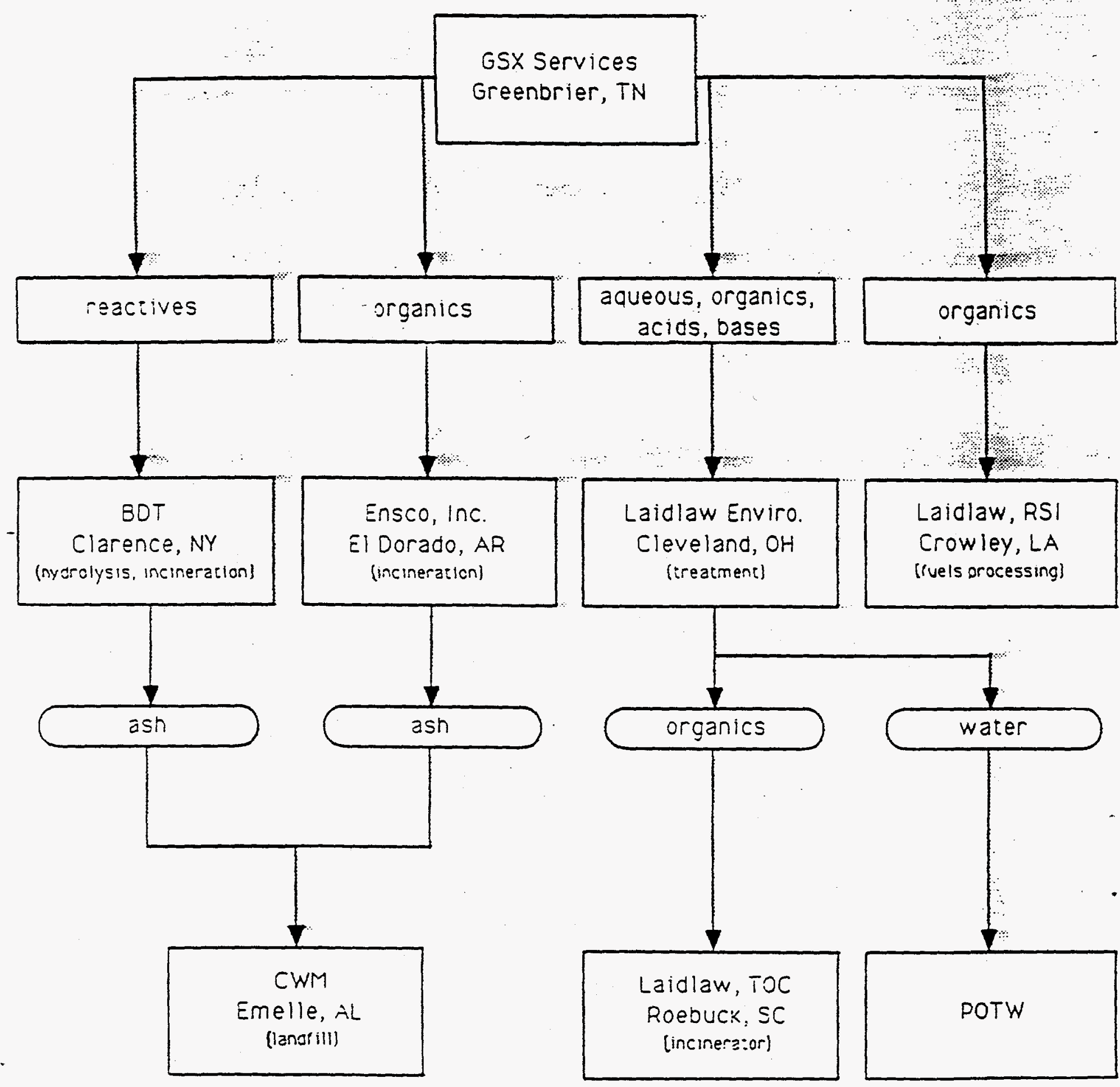


IDAHO NATIONAL ENGINEERING LABORATORY

for the U.: S. DEPARTMENT OF ENERGY

Waste Streams: Mixed Radioactive Waste (one approved waste stream) -ransporter: Tri-State Motor Transport

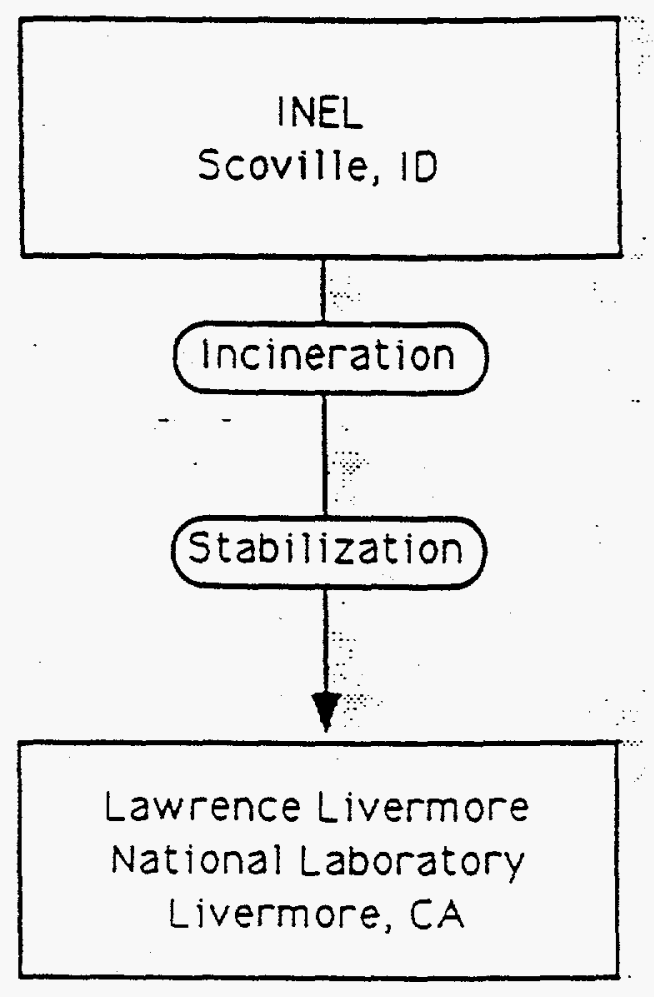


INTERSTATE: NUCLEAR SERVICES (INS)

'vaste Streams: Radioactive Laundry

iransporter:

interstate Nuclear Services

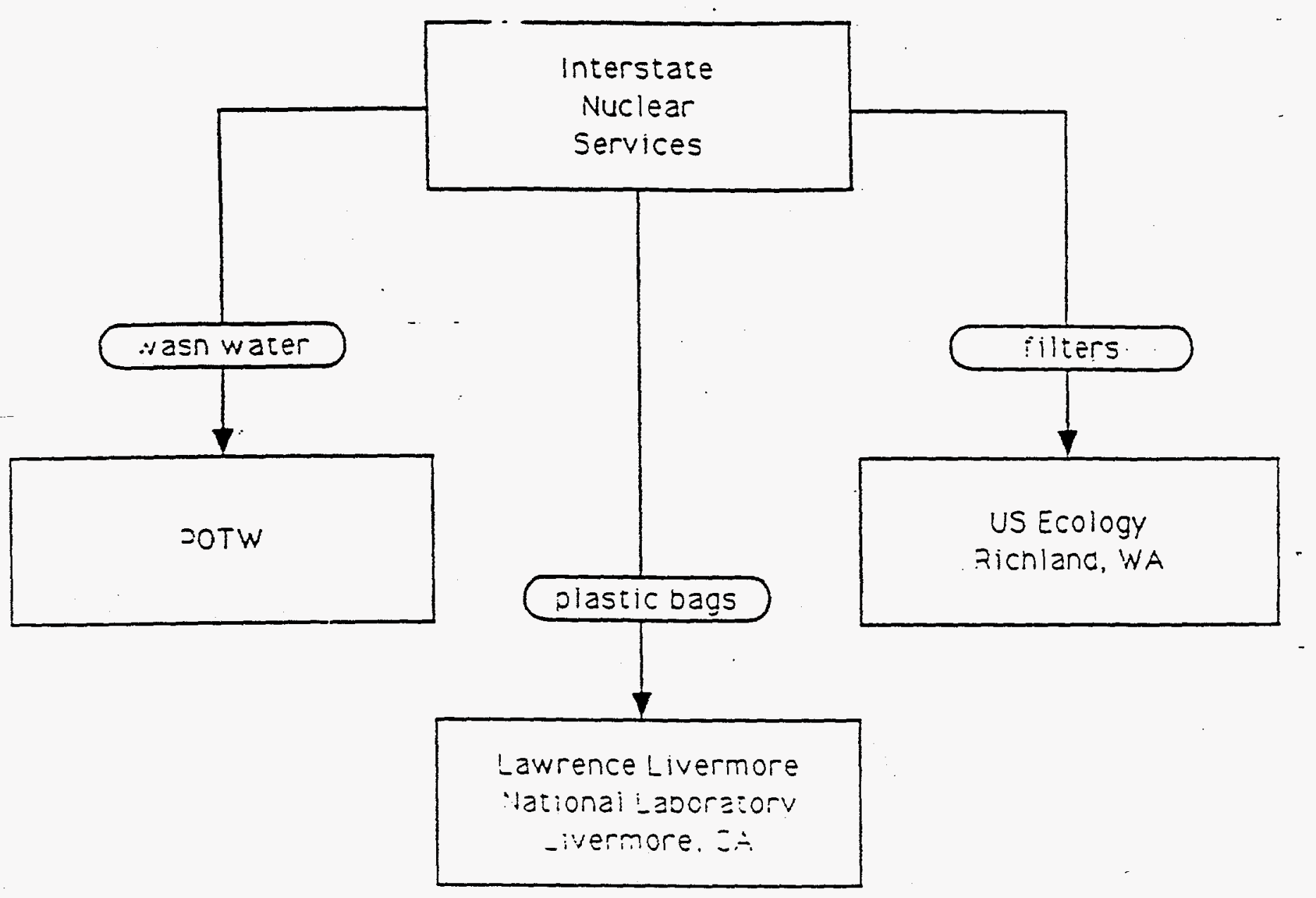


Waste Streams: Acids, Bases

Transporters: GSX, ExcelTrans, Tri-State Motor Transit

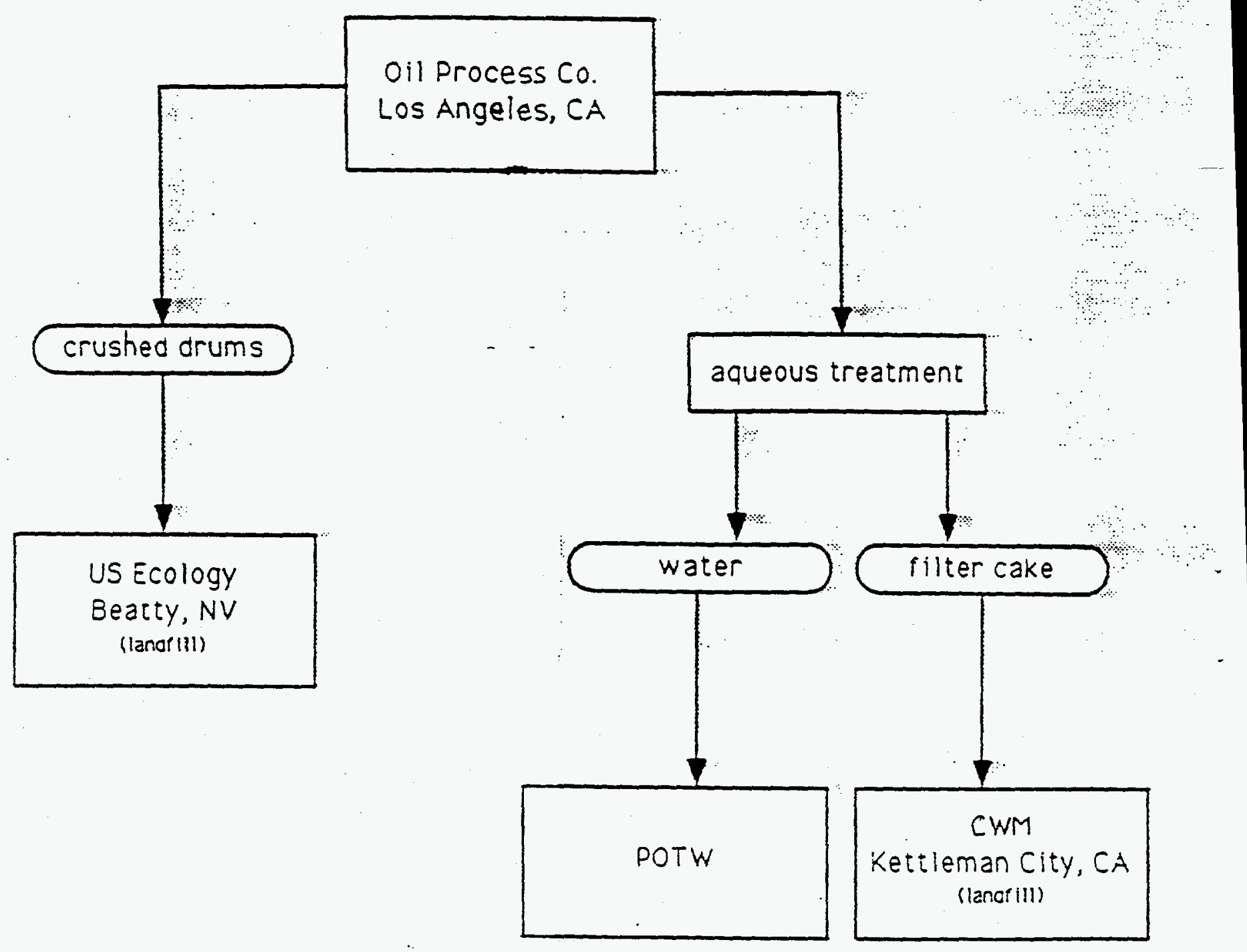


QUICKSILVER PRODUCTS, INC.

Waste Streams: Fluorescent tubes, metallic mercury

Transporters: IT Corp.

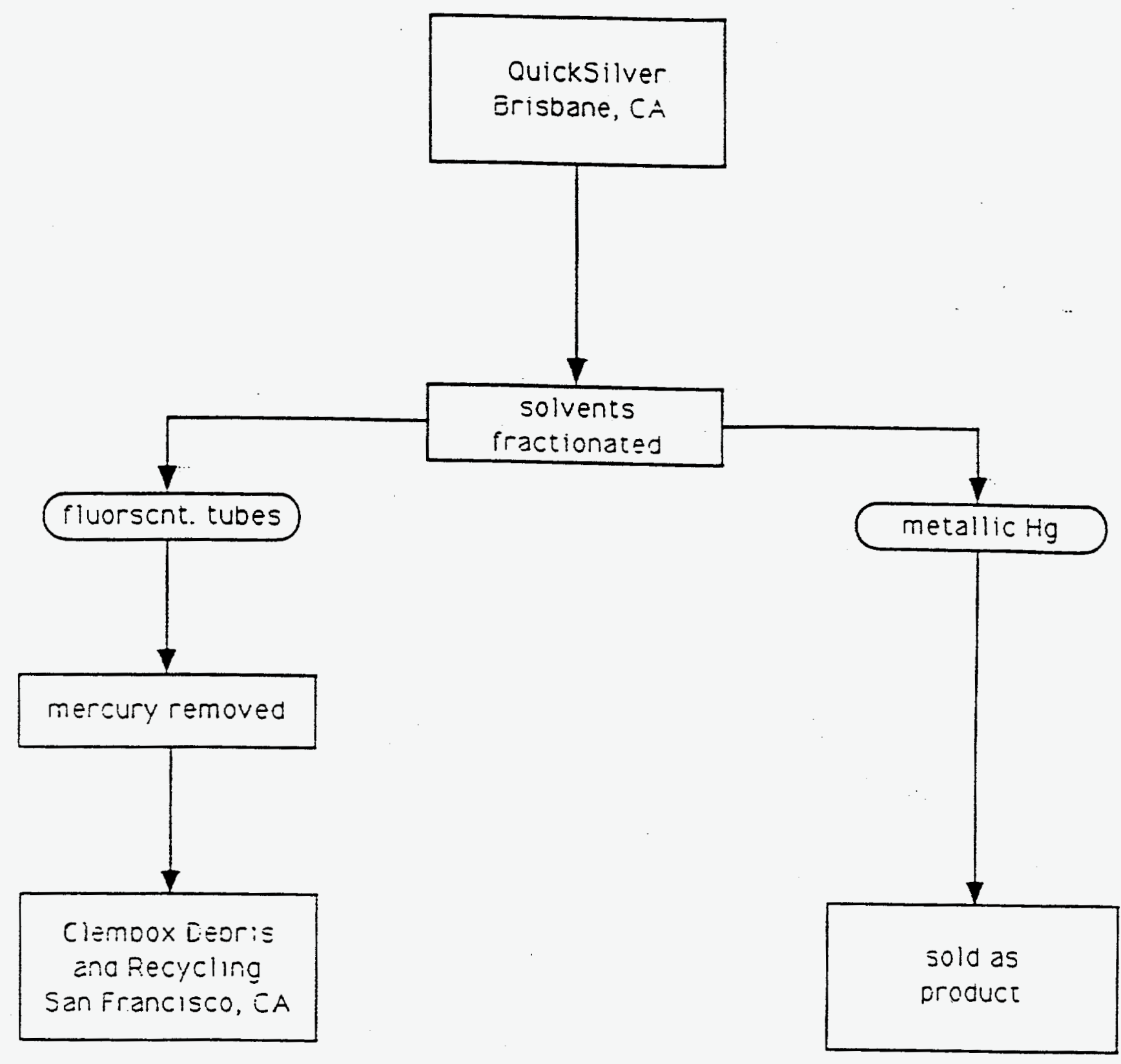


REYNOLDS ELECTRIC \& ENINEERING CO., INC. NEVADA TEST SITE for the U: S. DEPARTMENT OF ENERGY

Waste Streams: Radioactive Waste

Transporter. Tri-State Motor Transport

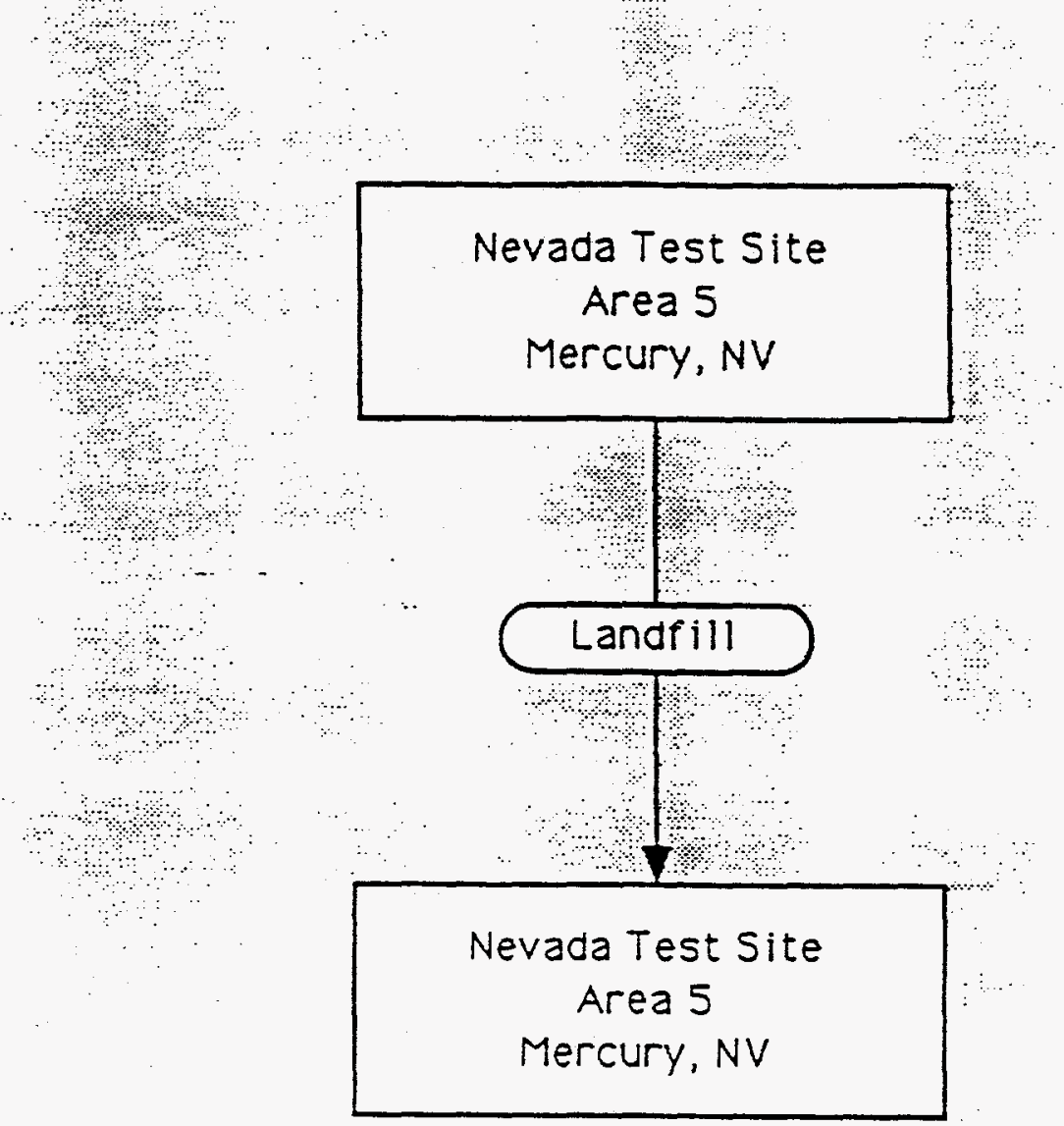


ROLLINS ENVIRONMENTAL SERVICES, TEXAS

Waste Streams: Labpacks.

Transporter: Trt-State Motor Transit Co:

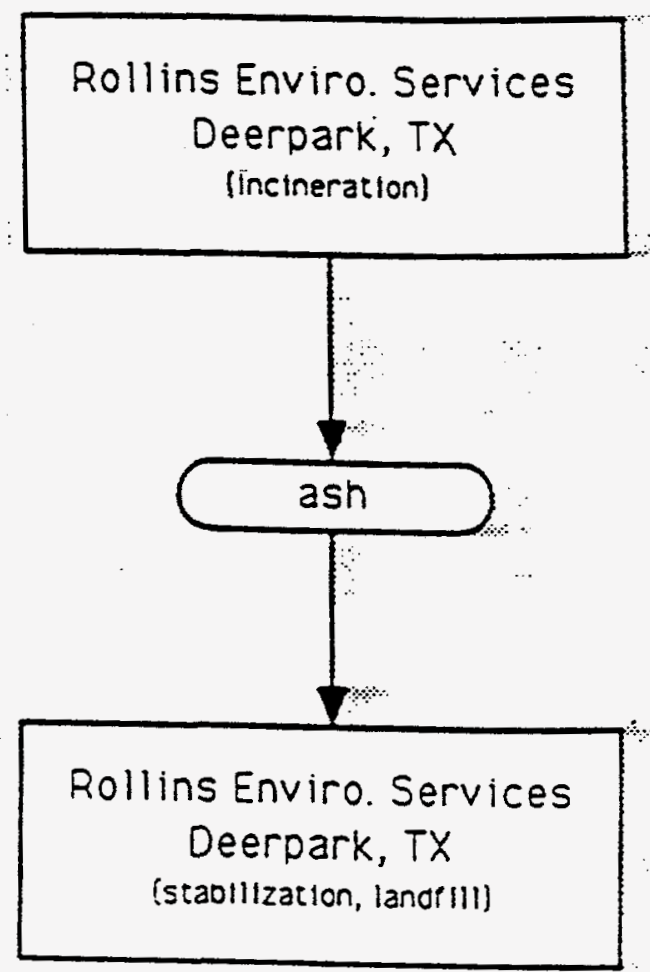


FOMIC CHEMICAL CORPORATION

Waste Streams: Organics, and Aqueous wastes with Organics

Transporters: Romic, GSX Services, and Excel Trans

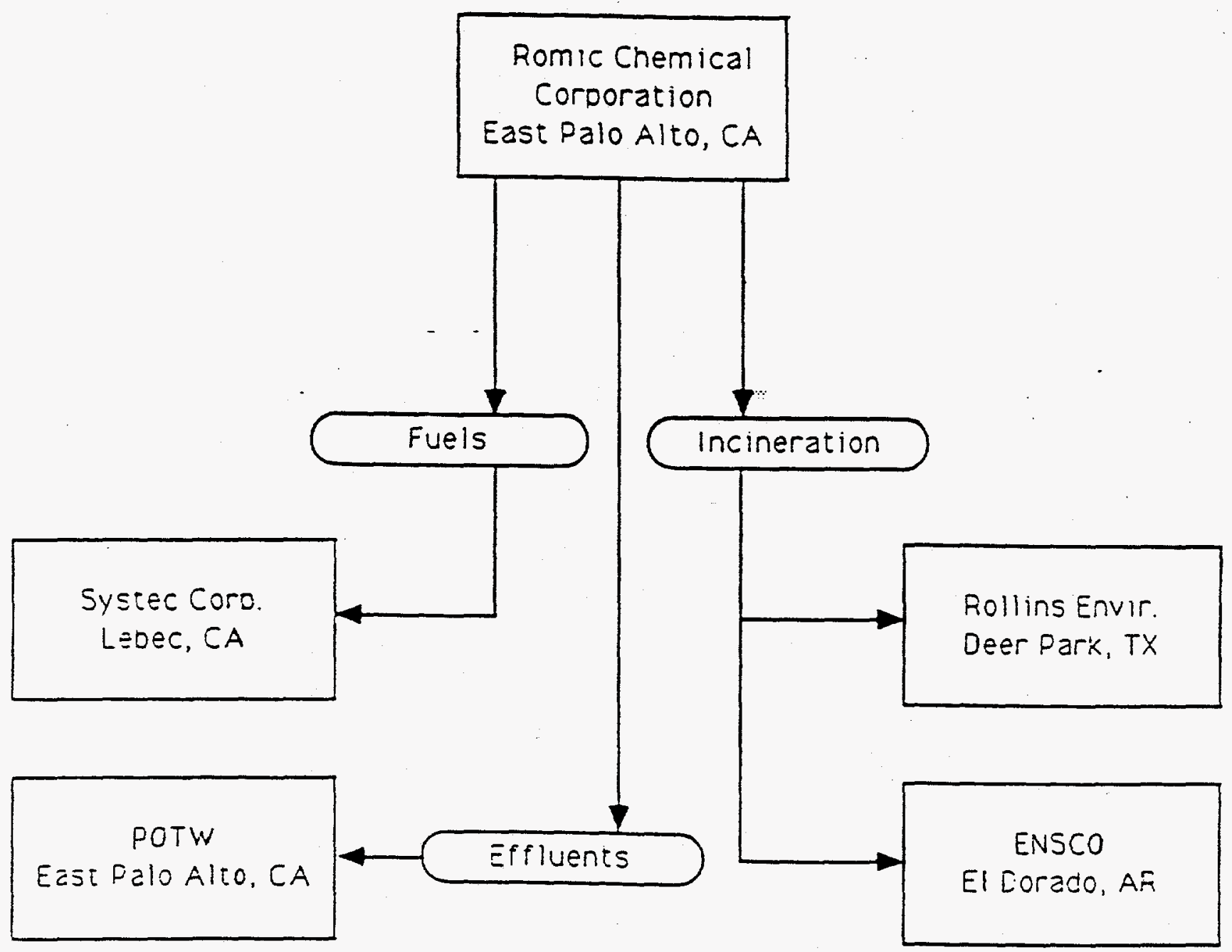


SAFETY KLEEN.

Waste Streams: Petroleum Napntha

Transporters: Safety-Kleen.

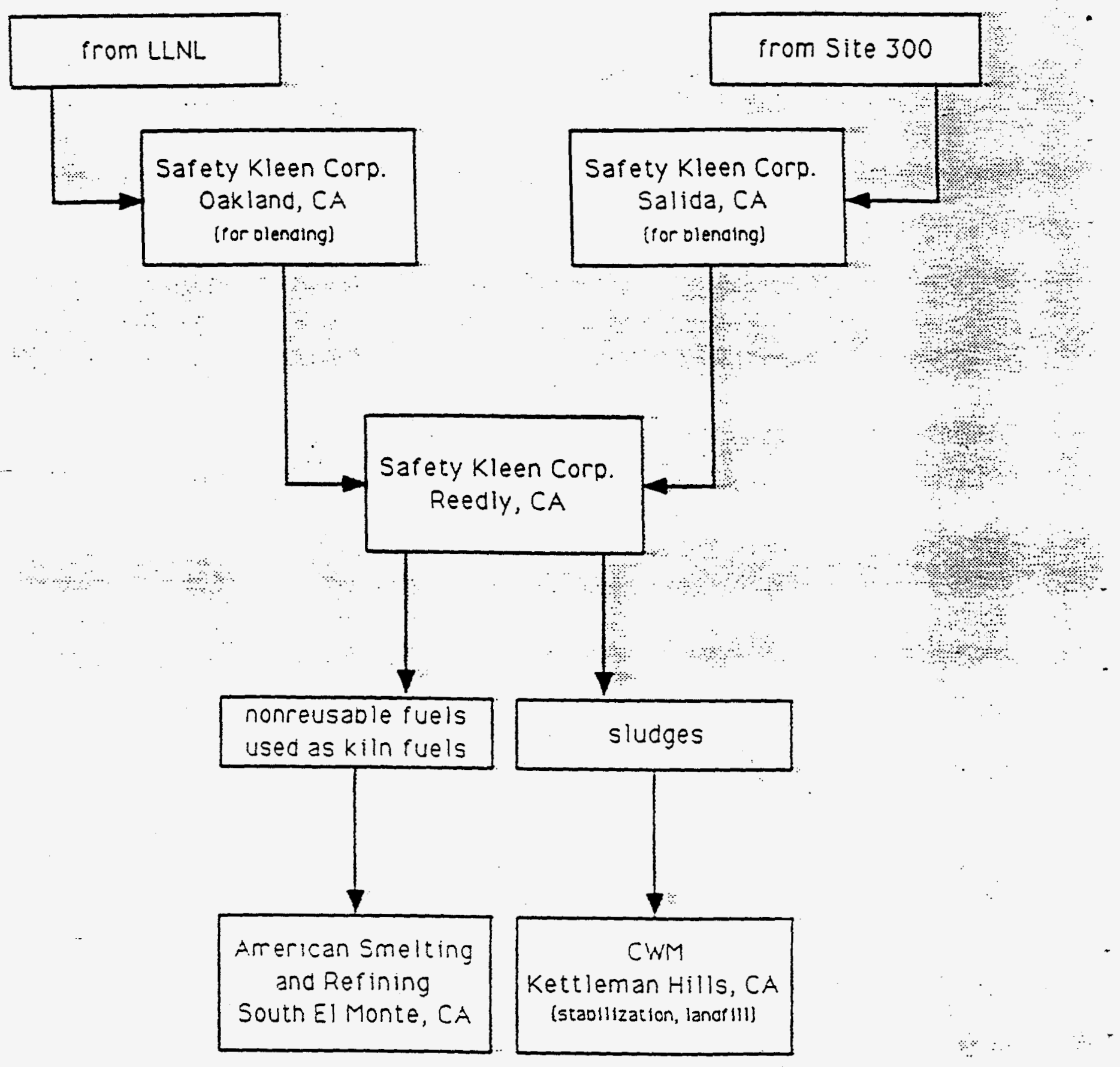


Waste Streams: Labpacks, Organics, Corrosives, and Aqueous wastes Transporters: Solvent Services, IT Corporation

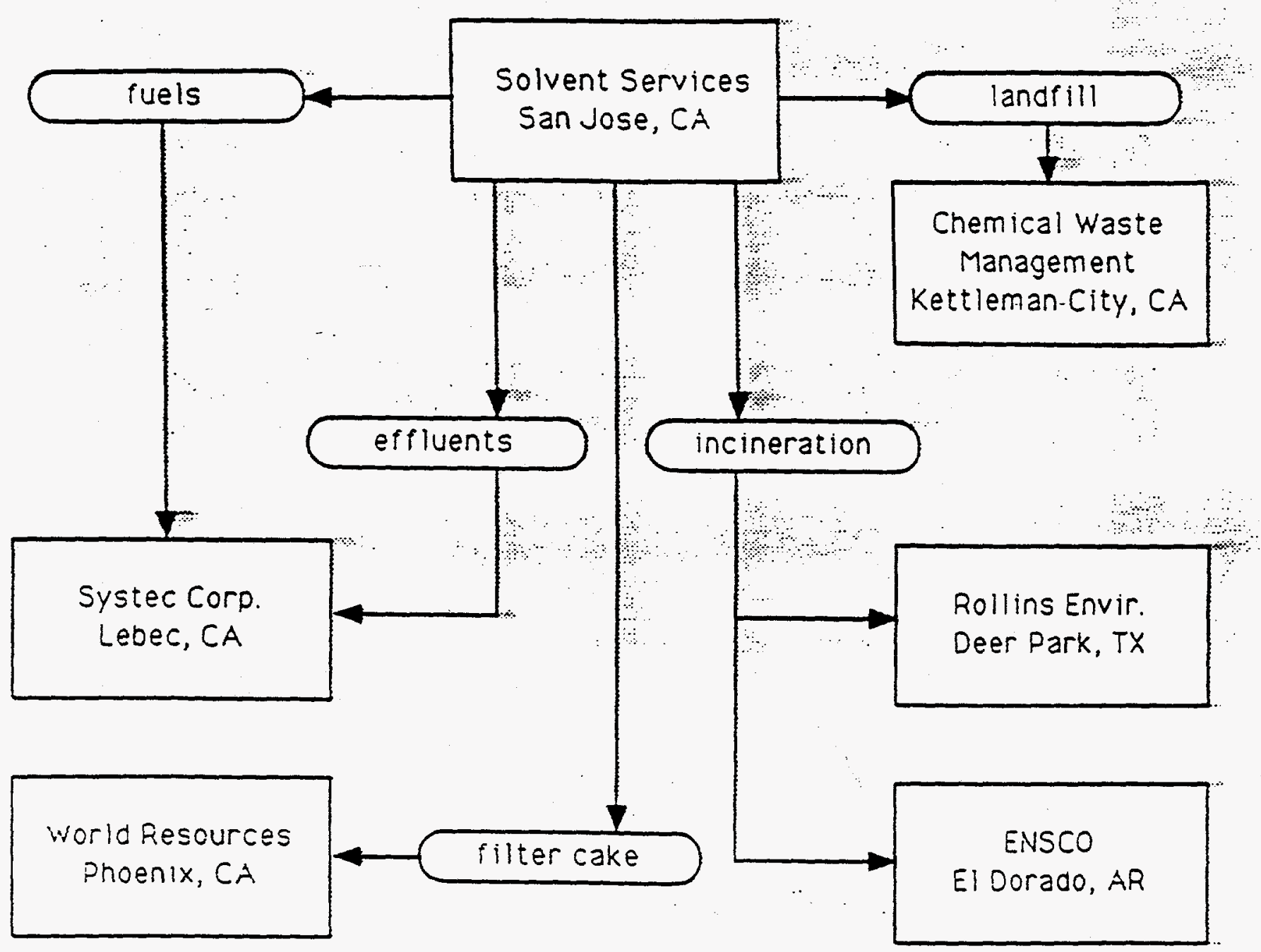


US POLLUTION CONTROL, GRASSY MOUNTAIN FACILITY

Waste Streams: Inorgante Aqueous Wastes; Paints, Olls, Asbestos, Oxidzers PCB contaminated debris, RCRA contaminated debris, and: Non-RCRA contaminated debris

Transporter: US Pollution Control:

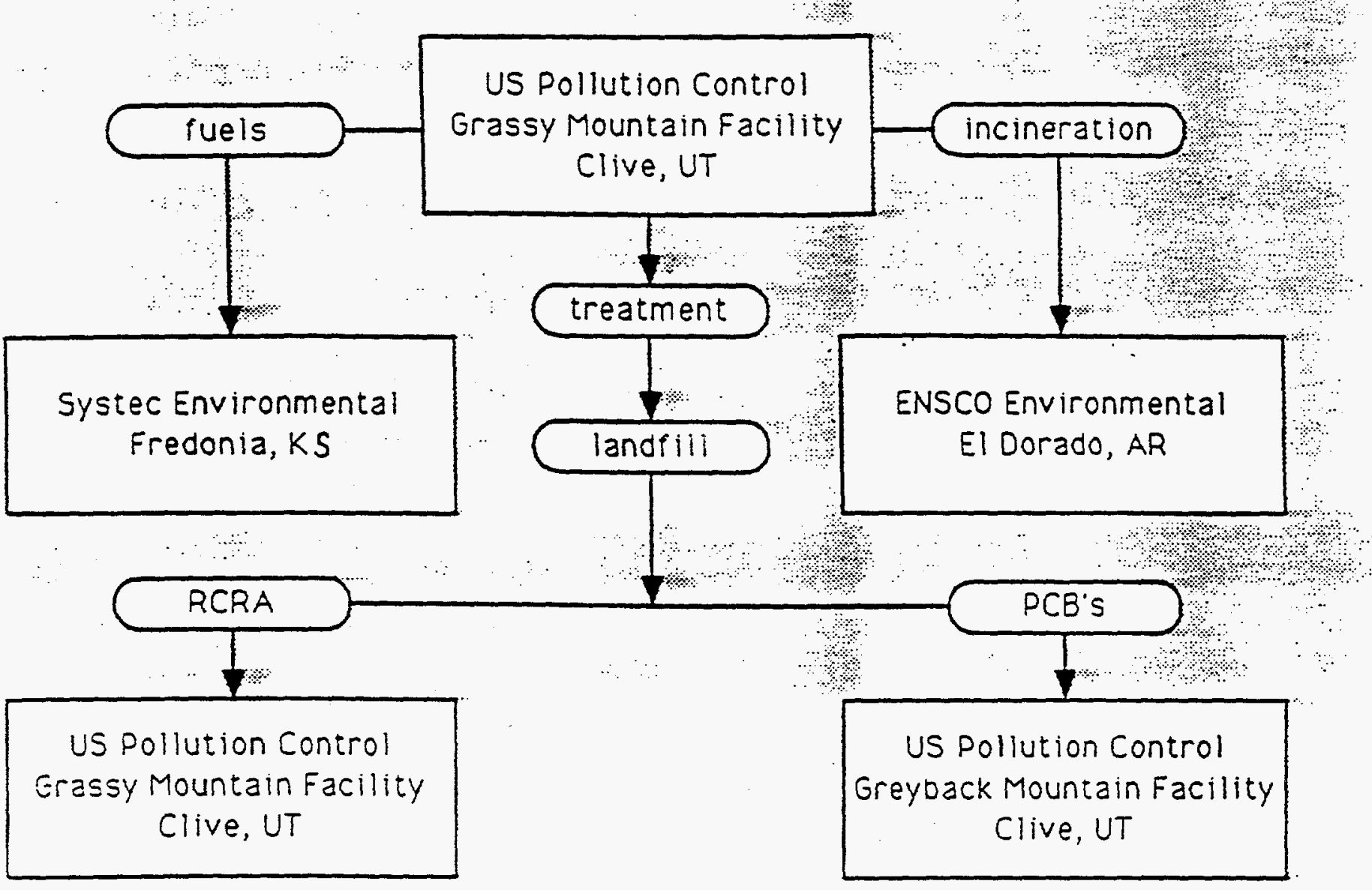


IS POLLUTION CONTROL, LONE MOUNTAIN FACILITY

$\therefore$ aste Streams: Aqueous wastes with Organics, Solvent contaminate Soil and Aqueous wastes with cyanides

- ensporter: US Pollution Control

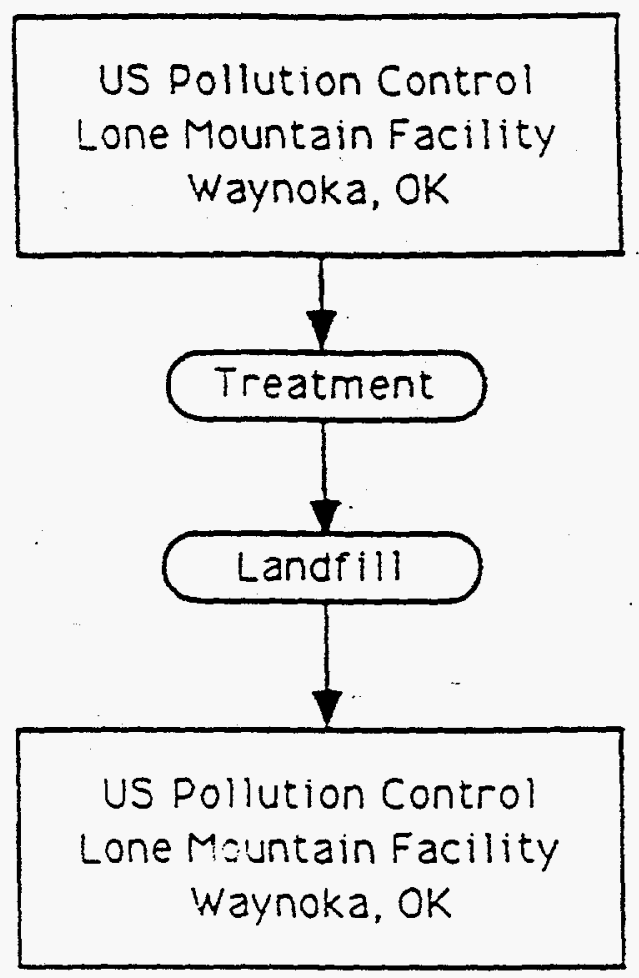




\section{APPENDIX B}

\section{Hazardous Waste Shipped Offsite January 1990 to July 1991}




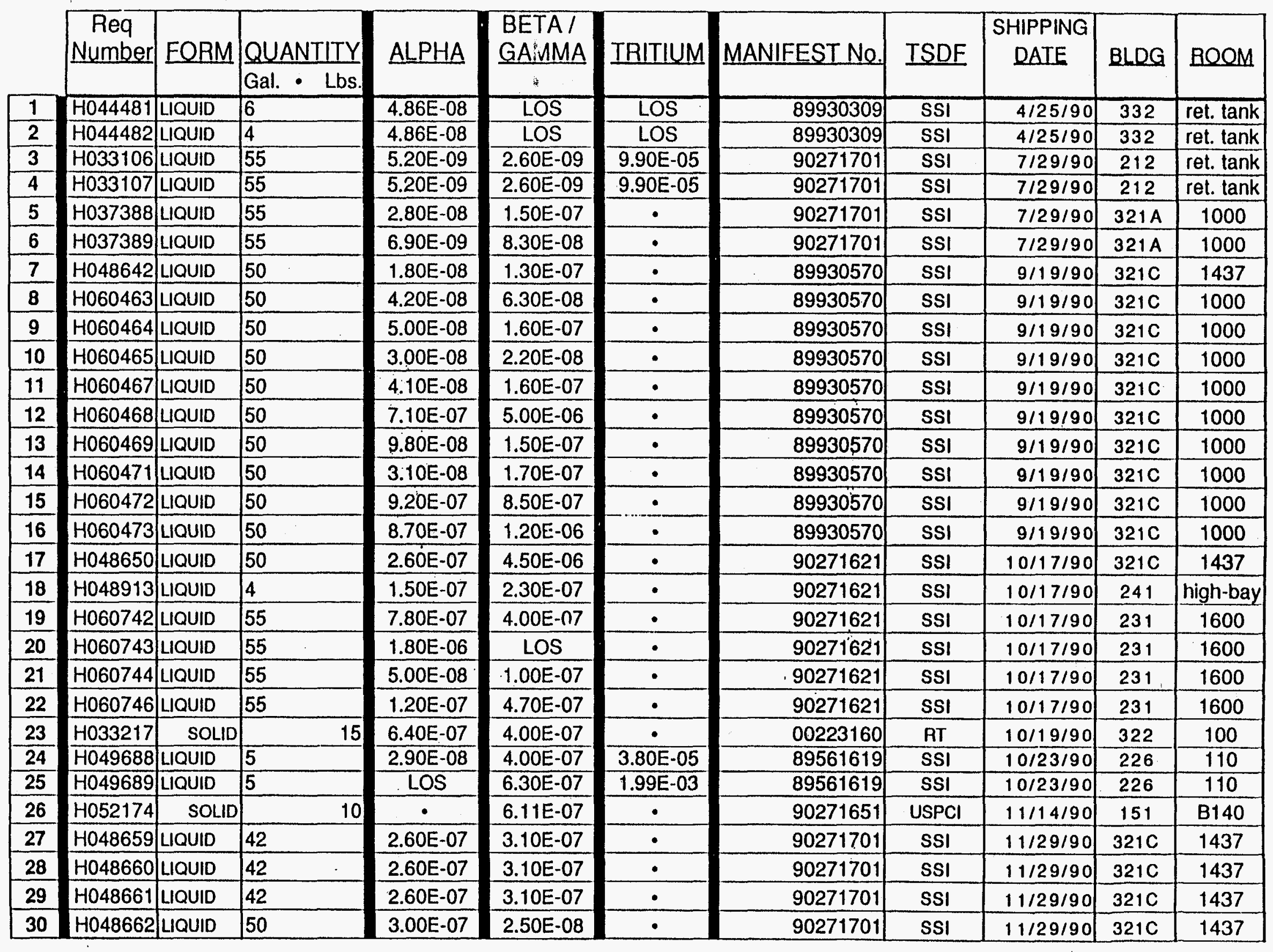




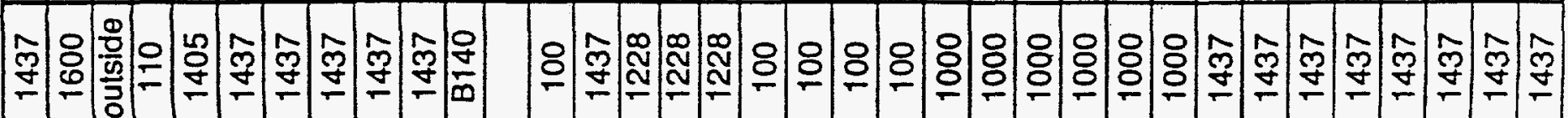

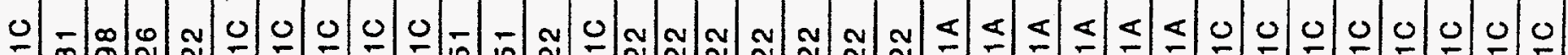

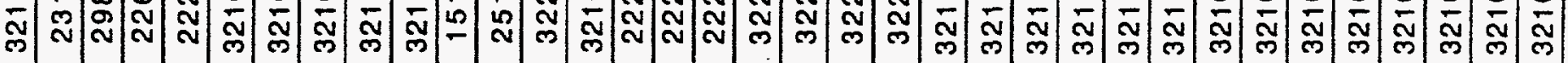

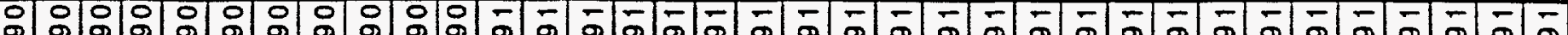

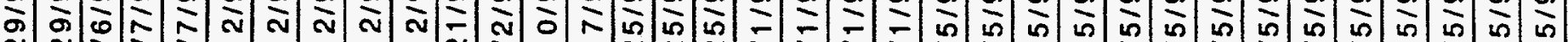

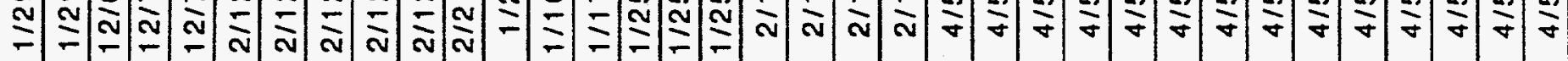

क क

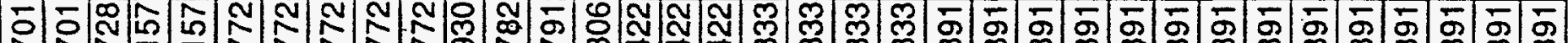

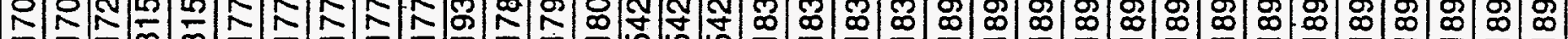
สิ ヘิ

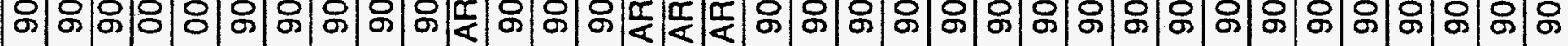

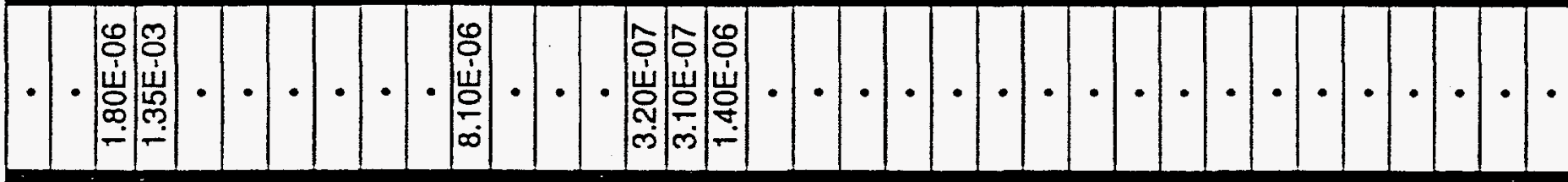

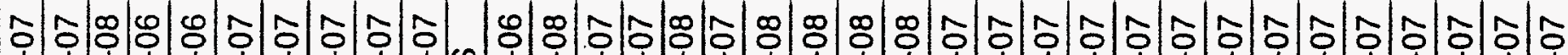

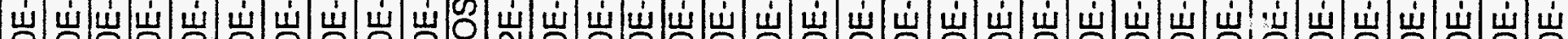

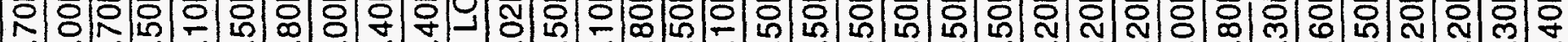

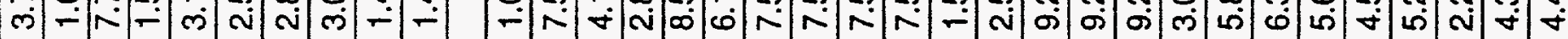

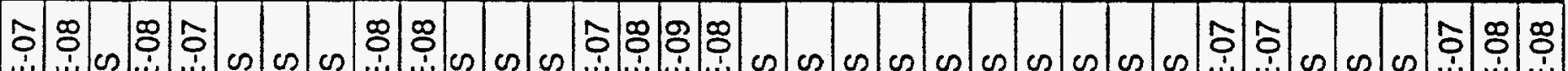

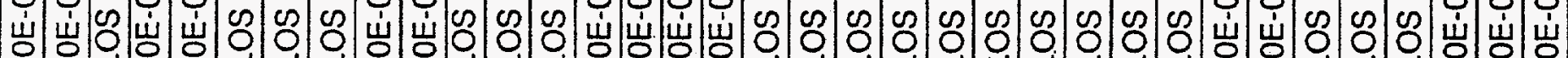

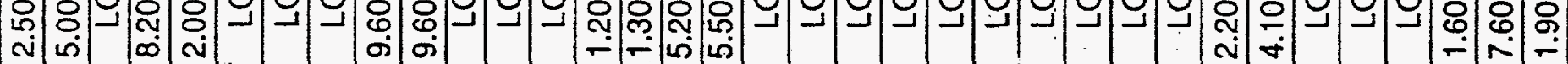

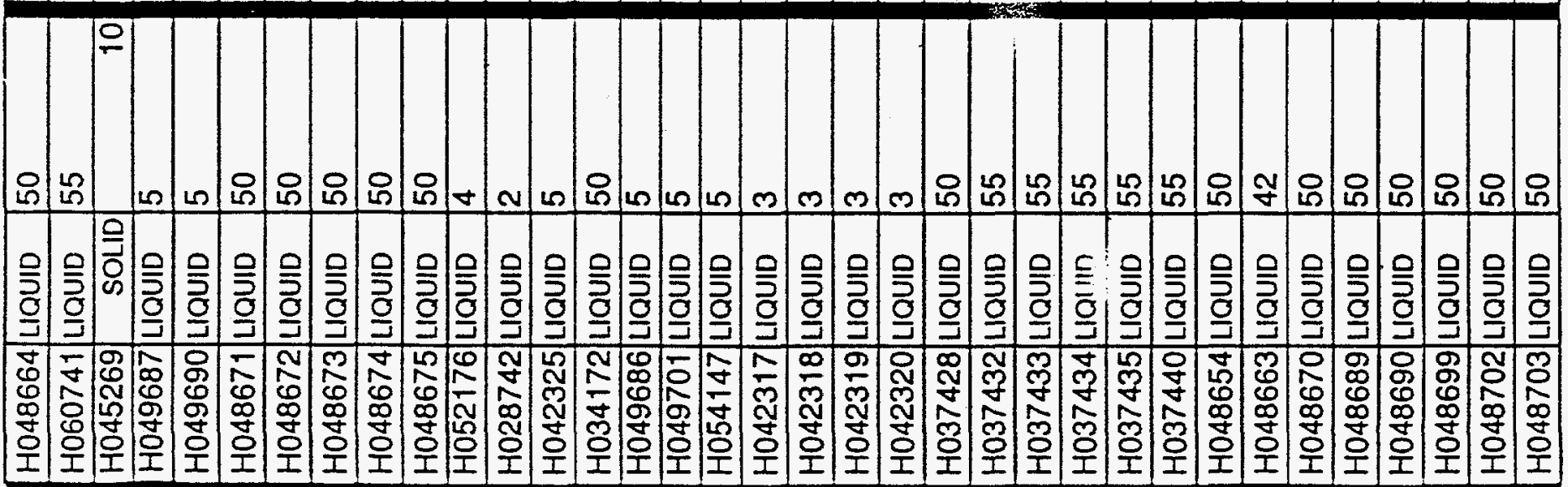

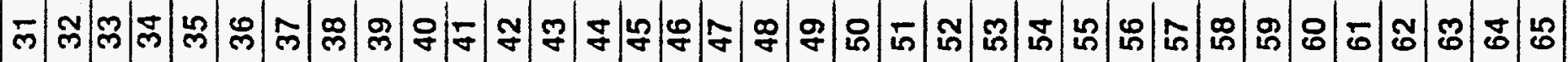




\begin{tabular}{|c|c|c|c|c|c|c|c|c|c|c|c|}
\hline 66 & $\mathrm{H} 060747$ & LIOUID & 55 & $4.50 \mathrm{E}-08$ & $7.10 \mathrm{E}-08$ & - & 90271891 & SSI & $4 / 5 / 91$ & 231 & 1600 \\
\hline 68 & $\mathrm{H} 048704$ & LIQUID & 5 & 5.20 E- 07 & 2.00E-07 & $\cdot$ & 90271902 & USPCI & $4 / 12 / 91$ & $321 \mathrm{C}$ & 1437 \\
\hline 70 & H061777 & LIQUID & 5 & LOS & 5.70E-07 & $1.80 \mathrm{E}-05$ & 90271902 & USPCI & $4 / 12 / 91$ & 222 & 1228 \\
\hline 71 & Ho66801 & LIQUID & 40 & - & 5.50E-07 & $\bullet$ & 90271905 & SSI & $4 / 16 / 91$ & $321 \mathrm{C}$ & 1000 \\
\hline 72 & H048684 & LIQUID & 50 & $1.70 \mathrm{E}-07$ & $2.60 E-07$ & - & 90271926 & SSI & $4 / 25 / 91$ & $321 \mathrm{C}$ & 1437 \\
\hline 75 & H052202 & SOLID & 15 & $3.60 \mathrm{E}-08$ & LOS & - & 90271939 & USPCI & $5 / 8 / 91$ & 151 & 1130 \\
\hline 76 & H034156 & LIQUID & 5 & $2.50 E-09$ & $1.60 \mathrm{E}-07$ & - & 90271966 & NORRIS & $6 / 20 / 91$ & 254 & 113 \\
\hline
\end{tabular}

LOS Below the Limit Of Sensitivity

- Designates zero or no analysis available

All Radioactivity values are $\mu \mathrm{Ci} / \mathrm{ml}$ for Liquids and $\mu \mathrm{Ci} / \mathrm{gm}$ for Solids.

ETICAM ETICAM

2095 Newlands Drive East, Fernley, NV 89408

GSX GSX SERVICES INC.

3815 Old Greenbrier Pike, Greenbrier, TN 37073

NORRIS NORRIS ENVIRONMENTAL SERVICES

5215 South Boyle Avenue, Los Angeles, CA 90058

OPC OIL PROCESS COMPANY

1848 East 55th Street, Los Angeles, CA 90058

RT ROLLINS ENVIRONMENTAL SERVICES

2027 Battleground Road, Deerpark, TX 77536

SSI SOLVENT SERVICES INC.

1021 Berryessa Road, San Jose, CA 95133

TOC LAIDLAW ENVIRONMENTAL SERVICES, Inc. 
APPENDIX C

RMMA Table 
Mais Siation L

TO:

FROM:

Joel Wong

SUBJECT: List of Access Control Areas

Attached is a current list of access control areas at LLNL where there is some potential for radioactive contamination. The potential for radioactive contamination exists in those areas where unencapsulated material is handled or where there is the potential for the production of activation products from high energy accelerators. This list was extracted from the master set of facility drawings which delineate all of the radiological and access control areas at LLNL which is maintained in the Health Physics Group Office. This list replaces the previous master list dated $10 / 04 / 91$.

This list is also being submitted to the Group Leader of Environmental Operations in the Environmental Protection Department. Additions are in bold print, deletions are in print marked with a "strikethru" symbol.

If I can provide any additional information, please let me know.

DSM:agm

DSM/Wong911018

Attachment

cc: J. Elliott, L-545

K. Gilbert, L-620

J. Hirabayashi, L-633 
Master List - 10/18/91

Access Control Areas and Radiological Areas in LLNL Facilities With Potential for Contamination or Activation

\begin{tabular}{|c|c|}
\hline Bldg. & Room \\
\hline 131 & $\begin{array}{l}1221 \\
1221 \mathrm{P} \\
1222 \\
1224 \\
1228 \\
1230 \\
1234 \\
1234 \mathrm{~A} \\
1236 \\
1238 \\
1240 \\
1259 \\
1259 A \\
1341 \\
1341 \mathrm{~A} \\
1345 \\
1345 \mathrm{~A} \\
1349 \\
1431 \\
1439 \\
1441 \\
1450 \\
1450 \mathrm{~A} \\
1450 \mathrm{C} \\
1460 \\
1471 \\
1481 \\
2228 \\
2234 \\
2238 \\
2240 \\
2240 \mathrm{~A} \\
2246 \\
2250 \\
2329 \\
2333 \mathrm{~A} \\
2335 \\
2347\end{array}$ \\
\hline 131 & $\begin{array}{l}2351 \\
2357 \\
2431 \\
2440 \\
2450\end{array}$ \\
\hline
\end{tabular}

\begin{tabular}{|c|c|}
\hline 151 & $\begin{array}{l}1033 \\
1034 \\
1034 \mathrm{~B} \\
1039 \\
1040 \\
1041 \\
1043 \\
1043 \mathrm{~A} \\
1123 \\
1138 \\
1140 \\
1318 \\
1322 \\
1326 \\
1326 \mathrm{~A} \\
1330 \\
1334 \\
1334 \mathrm{~B} \\
2103 \\
2107 \\
2109 \\
2117 \\
2121 \\
2125 \\
2125 \mathrm{~A} \\
2131 \\
2302 \\
2302 \mathrm{~A} \\
2308 \\
2312 \\
2314 \\
2318 \\
2318 \mathrm{~A}\end{array}$ \\
\hline 151 & $\begin{array}{l}2322 \\
2322 A \\
2326 \\
2326 A \\
2330 \\
2330 A\end{array}$ \\
\hline 171 & $\begin{array}{l}107 \\
111 \\
\end{array}$ \\
\hline 175 & $\begin{array}{l}100 \\
103 \\
112 \\
124 \\
128\end{array}$ \\
\hline
\end{tabular}

\begin{tabular}{|c|c|}
\hline 177 & $\begin{array}{l}1000 \\
1010 \\
1014 \\
1020 \\
1021 \\
1024 \\
1025 \\
1027\end{array}$ \\
\hline 179 & $\begin{array}{l}1000 \\
1020\end{array}$ \\
\hline 190 & $\begin{array}{l}1000 \\
1000 \mathrm{~A}\end{array}$ \\
\hline 194 & $\begin{array}{l}1131 \\
1300 \\
\text { B122A } \\
\text { B130 } \\
\text { B132 }\end{array}$ \\
\hline 212 & $\begin{array}{l}174 \\
184\end{array}$ \\
\hline 222 & $\begin{array}{l}1105 B \\
1106 \\
1117 \mathrm{~B} \\
1118 \\
1118 \mathrm{~B} \\
1154 \\
1216 \\
1216 \mathrm{~B} \\
1223 \\
1228 \\
1228 \mathrm{~B} \\
1365 \\
1365 \mathrm{~B} \\
1421 \\
1506 \mathrm{~B}\end{array}$ \\
\hline 222 & $\begin{array}{l}1511 \\
1511 \mathrm{~B} \\
1514 \\
1515 \\
1515 \mathrm{~B} \\
1520 \\
1520 \mathrm{~B} \\
1524 \mathrm{~B}\end{array}$ \\
\hline 226 & $\begin{array}{l}106 \\
109 \\
110 \\
113\end{array}$ \\
\hline
\end{tabular}

\begin{tabular}{|c|c|}
\hline 231 & $\begin{array}{l}1318 \\
1330 \\
1351 \\
1427 \\
1712 \\
1737 \\
1841 \\
190 \mathrm{HB} \\
1944 \mathrm{~A} \\
1944 \mathrm{~B} \\
1945 \\
1945 \mathrm{~A} \\
1945 \mathrm{~B} \\
1945 \mathrm{C} \\
1945 \mathrm{D} \\
1945 \mathrm{E} \\
1956 \mathrm{~A} \\
1956 \mathrm{~B} \\
1963 \\
2934\end{array}$ \\
\hline 233 & 1100 \\
\hline 235 & $\begin{array}{l}1100 \\
1101 \\
1107 \\
1109 \\
1121 \\
1122 \\
1123 \\
1125 \\
1131 \\
1133 \\
1133 \mathrm{~A} \\
1133 \mathrm{~B} \\
1136 \\
1138 \\
1206 \\
1222 \\
1224 \\
1226 \\
1235 \\
1251 \\
\mathrm{~B} 200 \mathrm{~B} \\
\mathrm{~B} 200 \mathrm{D} \\
\mathrm{B} 200 \mathrm{~F} \\
\mathrm{~B} 200 \mathrm{G}\end{array}$ \\
\hline 241 & $\begin{array}{l}1600 \\
1686 \\
1858 \mathrm{~A} \\
1887\end{array}$ \\
\hline 243 & 2018 \\
\hline
\end{tabular}


Master List - 10/18/91

Access Control Areas and Radiological Areas in LLNL Facilities With Potential for -

\begin{tabular}{|l|l|}
\hline 251 & $1001 \mathrm{~B}$ \\
& $1001 \mathrm{C}$ \\
& 1003 \\
& 1027 \\
& 1035 \\
& 1047 \\
& 1048 \\
& 1053 \\
& 1102 \\
& 1117 \\
& 1142 \\
& 1150 \\
& 1211 \\
& 1212 \\
& 1232 \\
& 1234 \\
& 1335 \\
& 1310 \\
& 1314 \\
& 1354 \\
& 1363 \\
& 1364 \\
& 2122 \\
\hline 253 & 1708 \\
& $1708 \mathrm{~A}$ \\
& $1708 \mathrm{~B}$ \\
& 1712 \\
& 1716 \\
& $1722 \mathrm{~A}$ \\
& 1726 \\
& 1732 \\
& 1734 \\
& 1903 \\
& 1906 \\
& 1909 \\
& 1910 \\
& 1913 \\
& $1913 \mathrm{~A}$ \\
\hline 254 & 1914 \\
\hline & 105 \\
& 109 \\
\hline 255 & 113 \\
\hline & 179 \\
& 180 \\
\hline 281 & 1305 \\
& -1307 \\
& 1311 \\
& 1319 \\
& 1323 \\
\hline & 1000 \\
& \\
\hline & \\
\hline
\end{tabular}

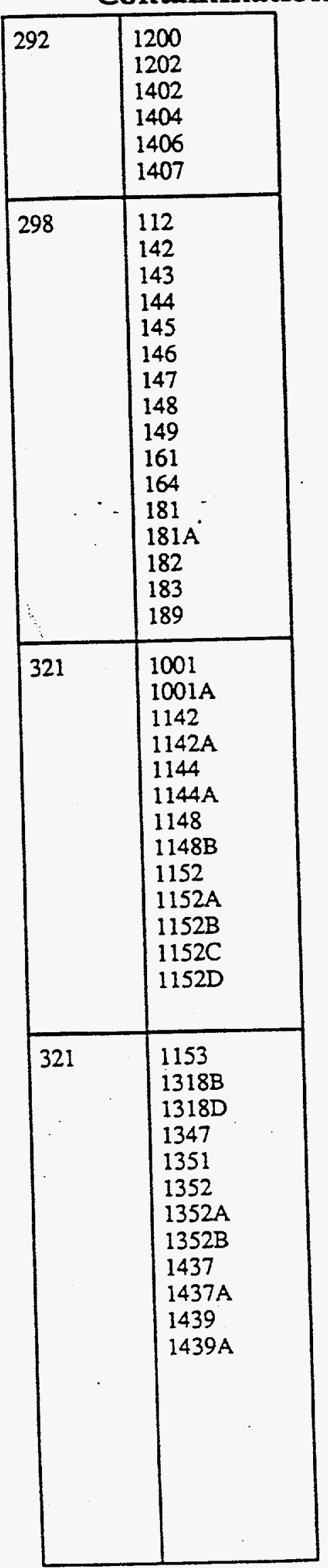

\begin{tabular}{|l|l|}
\hline 331 & 127 \\
130 \\
131 \\
134 \\
135 \\
138 \\
139 \\
142 \\
143 \\
144 \\
$144 A$ \\
$144 B$ \\
145 \\
146 \\
148 \\
149 \\
$149 A$ \\
$149 B$ \\
150 \\
153 \\
$153 A$ \\
$153 B$ \\
154 \\
157 \\
158 \\
161 \\
1001 \\
1005 \\
1009 \\
1011 \\
1013 \\
1015 \\
1016 \\
1017 \\
1018 \\
1019 \\
1020 \\
1021 \\
1022 \\
1023 \\
1024 \\
1025 \\
1027 \\
1029 \\
1035 \\
1037 \\
1045 \\
1047 \\
1049 \\
1051 \\
1100 \\
1101 \\
1103 \\
\\
\\
\\
\\
\\
\end{tabular}

\begin{tabular}{|c|c|}
\hline 331 & $\begin{array}{l}1104 \\
1105 \\
1107 \\
1108 \\
1117 \\
1119 \\
1121 \\
1123 \\
1124 \\
1126 \\
1128 \\
1200 \\
1200 A \\
1210 \\
1215 \\
\text { Yard }\end{array}$ \\
\hline 332 & $\begin{array}{l}1005 \\
1005 \mathrm{~A} \\
1006 \\
1006 \mathrm{~A} \\
1009 \\
1010 \\
1013 \\
1050 \\
1051 \\
1313 \\
1313 \mathrm{~A} \\
1313 \mathrm{~B} \\
1314 \\
1314 \mathrm{~A} \\
1321 \\
1321 \mathrm{~A} \\
1322 \\
1322 \mathrm{~A} \\
1322 \mathrm{~B} \\
1322 \mathrm{C} \\
1329 \\
1330 \\
1330 \mathrm{~A} \\
1337 \\
1337 \mathrm{~A} \\
1337 \mathrm{~B} \\
1338 \\
1345 \\
1346 \\
1353 \\
1354 \\
1354 \mathrm{~A} \\
1361 \\
1362 \\
1369 \\
1370 \\
1377 \\
1378 \\
2300 \\
\mathrm{~B} 100 \\
13 \\
\end{array}$ \\
\hline
\end{tabular}


Master List - 10/18/91

Access Control Areas and Radiological Areas in LLNL Facilities With Potential for

\begin{tabular}{|c|c|}
\hline 341 & $\begin{array}{l}1003 \\
1005 \\
1009\end{array}$ \\
\hline 361 & $\begin{array}{l}1245 \\
1342 \\
1346 \\
1347 \\
1445 \\
1446 \\
1542 \\
1564 \\
1635 \\
1642 \\
1649 \\
1664 \\
1658 C \\
1742 \\
1745\end{array}$ \\
\hline 363 & 1008 \\
\hline 365 & $\begin{array}{l}104 \\
109 \\
112\end{array}$ \\
\hline 366 & 103 \\
\hline 377 & $\begin{array}{l}1003 \\
1028\end{array}$ \\
\hline 378 & 120 \\
\hline 381 & $\begin{array}{l}\text { B150 } \\
\text { B154 } \\
\text { B156 }\end{array}$ \\
\hline 391 & $\begin{array}{l}\text { Nova Target } \\
\text { Chamber }\end{array}$ \\
\hline 412 & 1246 \\
\hline 419 & $\begin{array}{l}124 \\
155 \\
167\end{array}$ \\
\hline 490 & 1061 \\
\hline 493 & 1000 \\
\hline 513 & $\begin{array}{l}1000 \\
1002\end{array}$ \\
\hline 514 & $\begin{array}{l}108 \\
110 \\
124\end{array}$ \\
\hline 594 & 110 \\
\hline
\end{tabular}
Contamination or Activation

\begin{tabular}{|l|l|}
\hline 612 & $\begin{array}{l}100 \\
612-4\end{array}$ \\
\hline $614 \mathrm{~W}$ & 1001 \\
\hline 624 & $612-2$ \\
\hline 625 & 1000 \\
\hline 801 & $\begin{array}{l}125 \\
\text { Firing Table }\end{array}$ \\
\hline 804 & $\begin{array}{l}\text { Open Area } \\
\text { Staging Area }\end{array}$ \\
\hline $810 \mathrm{~A}$ & $\begin{array}{l}109 \\
121 \\
133\end{array}$ \\
\hline $810 \mathrm{~B}$ & 100 \\
\hline 818 & 101 \\
\hline 851 & $\begin{array}{l}215 \\
\text { Firing Table }\end{array}$ \\
\hline 857 & 100 \\
\hline 2581 & $\begin{array}{l}101 \\
104\end{array}$ \\
\hline
\end{tabular}




\section{RMMA Classification by Building}

\begin{tabular}{|c|c|c|c|c|}
\hline Never & $\begin{array}{c}\text { None in the } \\
\text { last } 5 \text { yrs }\end{array}$ & $\begin{array}{c}\text { None in the } \\
\text { last } 2 \text { yrs }\end{array}$ & $\begin{array}{c}\text { Possible in } \\
\text { the last 2 yrs }\end{array}$ & $\begin{array}{c}\text { Current } \\
\text { RMMA }\end{array}$ \\
\hline
\end{tabular}

\begin{tabular}{|c|c|c|c|c|}
\hline & & & & \\
\hline \multicolumn{5}{|l|}{3} \\
\hline \multicolumn{5}{|l|}{4} \\
\hline \multicolumn{5}{|l|}{5} \\
\hline \multicolumn{5}{|l|}{6} \\
\hline \multicolumn{5}{|l|}{41} \\
\hline \multicolumn{5}{|l|}{$41 \mathrm{~A}$} \\
\hline \multicolumn{5}{|l|}{42} \\
\hline & 111 & & & \\
\hline \multicolumn{5}{|l|}{112} \\
\hline \multicolumn{5}{|l|}{113} \\
\hline \multicolumn{5}{|l|}{115} \\
\hline \multicolumn{5}{|l|}{116} \\
\hline \multicolumn{5}{|l|}{117} \\
\hline \multirow{2}{*}{\multicolumn{5}{|c|}{$\frac{118}{119}$}} \\
\hline & & & & \\
\hline \multicolumn{5}{|l|}{119} \\
\hline \multicolumn{5}{|l|}{122} \\
\hline \multicolumn{5}{|l|}{123} \\
\hline \multicolumn{5}{|l|}{125} \\
\hline & & & & 131 \\
\hline \multicolumn{5}{|l|}{132} \\
\hline & 141 & & & \\
\hline & & & & 151 \\
\hline \multicolumn{5}{|l|}{152} \\
\hline \multicolumn{5}{|l|}{153} \\
\hline \multirow{2}{*}{\multicolumn{5}{|c|}{$\frac{154}{160}$}} \\
\hline & & & & \\
\hline & & 161 & & \\
\hline & & & 162 & \\
\hline 163 & & & & \\
\hline \multicolumn{5}{|l|}{164} \\
\hline & 165 & & & \\
\hline & & 166 & & \\
\hline & 168 & & & \\
\hline & 169 & & & \\
\hline \multicolumn{5}{|l|}{$169 \mathrm{~A}$} \\
\hline $169 \mathrm{~B}$ & & & & \\
\hline 1690 & & & & \\
\hline 170 & & & & \\
\hline & & $\alpha$ & & 171 \\
\hline & 173 & & & \\
\hline & & & 174 & \\
\hline & & & & 175 \\
\hline & 176 & & & \\
\hline & & & & 177 \\
\hline
\end{tabular}


- RMMA Classification by Building

\begin{tabular}{|c|c|c|c|c|}
\hline Never & $\begin{array}{c}\text { None in the } \\
\text { last } 5 \text { yrs }\end{array}$ & $\begin{array}{c}\text { None in the } \\
\text { last } 2 \text { yrs }\end{array}$ & $\begin{array}{c}\text { Possible in } \\
\text { the last } 2 \text { yrs }\end{array}$ & $\begin{array}{l}\text { Current } \\
\text { RMMA }\end{array}$ \\
\hline
\end{tabular}

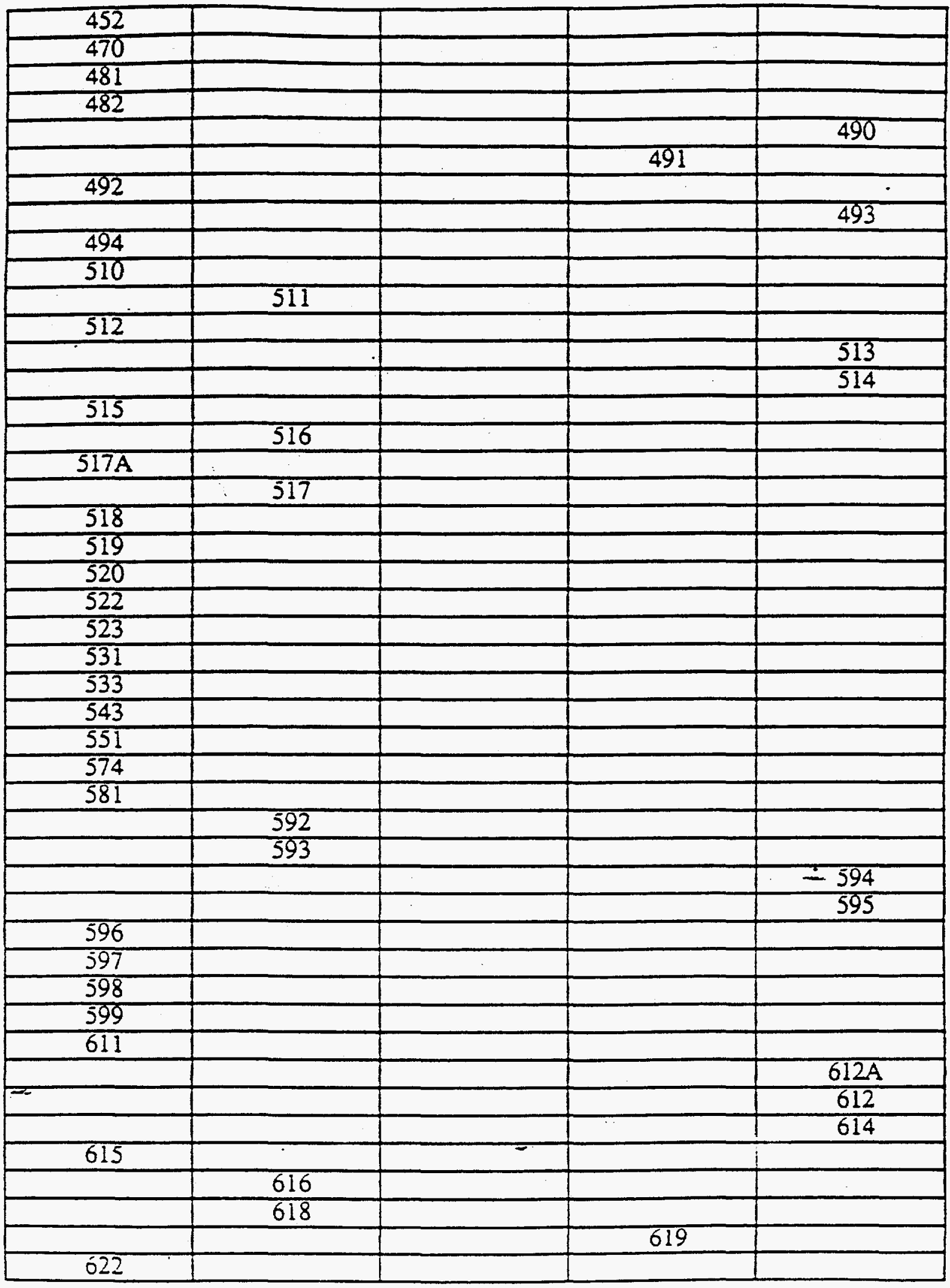


RMMA Classification by Building

\begin{tabular}{|c|c|c|c|c|}
\hline Never & $\begin{array}{c}\text { None in the } \\
\text { last } 5 \text { yrs }\end{array}$ & $\begin{array}{c}\text { None in the } \\
\text { last } 2 \text { yrs }\end{array}$ & $\begin{array}{c}\text { Possible in } \\
\text { the last } 2 \text { yrs }\end{array}$ & $\begin{array}{l}\text { Current } \\
\text { RMMA }\end{array}$ \\
\hline
\end{tabular}

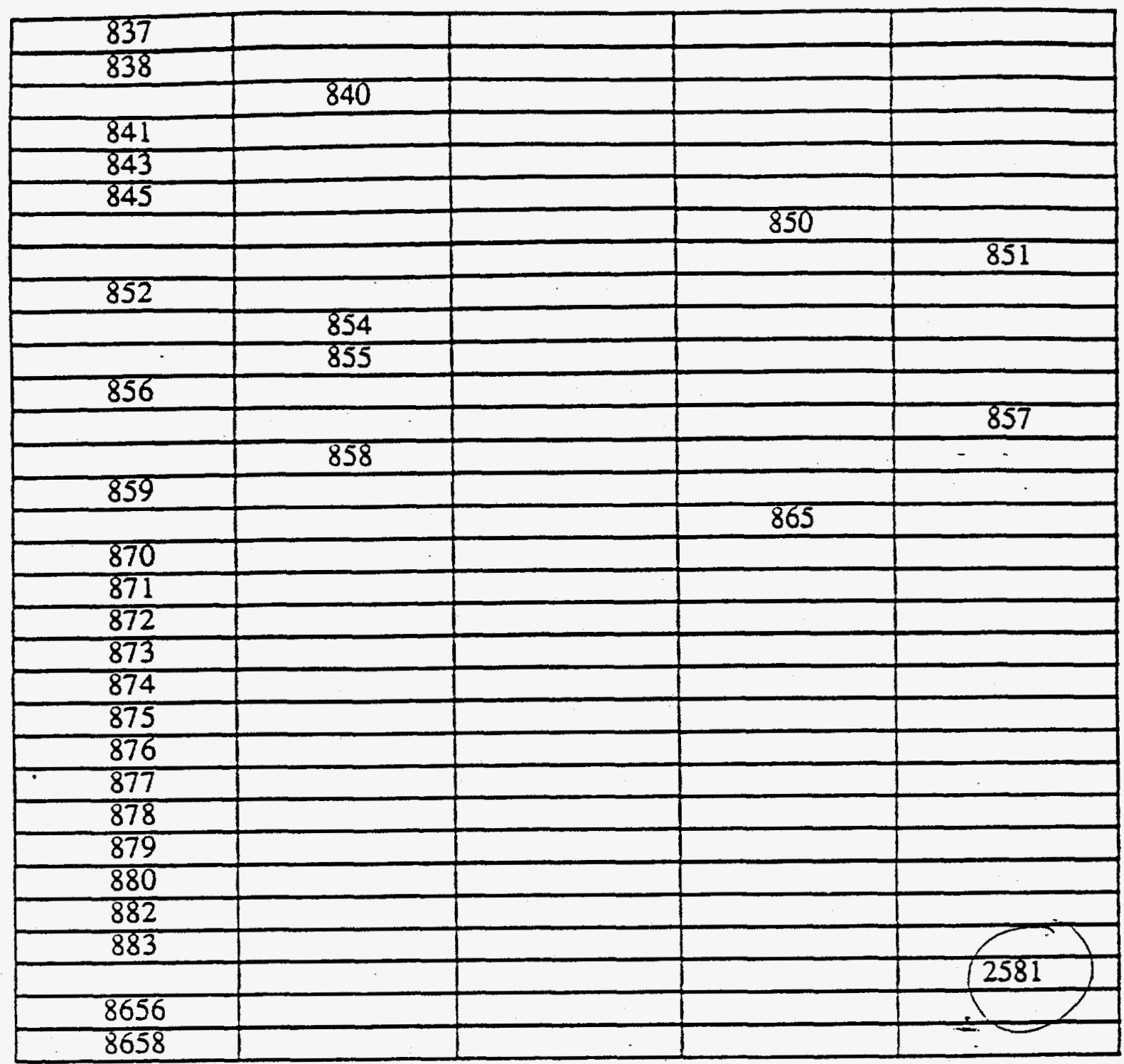




\section{APPENDIX D}

H-Req Data Summary 
Table D-1. Spot checked H-Req data summary.

\begin{tabular}{|c|c|c|c|c|c|c|c|c|c|c|c|c|c|c|}
\hline \multicolumn{3}{|c|}{ Spot Checked from files } & & & & & & & & & & & & Aqueous, \\
\hline & & & & & & & & & & & & Radiological Analysis & & Oil, solid, \\
\hline H-Req \# & Bldg \# & Room \# & RMMA? & H-Req Date & Manifest \# & Manifest Date & Sample \# & Swipe/Survey & Process Knowl & Comments & Gross Alpha & Gross Beta & $\mathrm{H}-3$ & sludge \\
\hline & & & & & . & & & & & & & & & \\
\hline Ho0517 & 161 & Tank & Not listed & $\mathbf{1} / \mathbf{1 9 / 8 9}$ & M87250958 & 1/31/89 & 8801778 & No & No & - & $3.9 \mathrm{E}-9 \mathrm{uCi} / \mathrm{ml}$ & $3.5 \mathrm{E}-8 \mathrm{uCi} / \mathrm{ml}$ & No & A \\
\hline H00518 & 169 & Not listed & Not listed & $2 / 9 / 89$ & Not listed & Not listed & 8801654 & No & No & No manifest listed & $9.9 \mathrm{E}-9 \mathrm{uCl} / \mathrm{ml}$ & $1.5 \mathrm{E}-8 \mathrm{uCi} / \mathrm{ml}$ & No & $\mathbf{A}$ \\
\hline Ho0530 & 169 & Not listed & Not listed & $2 / 9 / 89$ & See comment & $2 / 21 / 89$ & 8801772 & No & No & Put on Req H4692 & $7.5 \mathrm{E}-8 \mathrm{uCl} / \mathrm{ml}$ & ND & ND & A \\
\hline Hoo559 & 490 & Not listed & Not listed & $2 / 9 / 89$ & M87250967 & $3 / 3 / 89$ & 8900033 & No & No & Not released to sewer-excessive green color & ND & $1.6 \mathrm{E}-8 \mathrm{uCi} / \mathrm{ml}$ & No & A \\
\hline Ho0568 & 612 & NA & Not listed & $2 / 8 / 89$ & M88610723 & $6 / 1 / 89$ & 8801621 & No & No & Part of overpack & No & No & No & 0 \\
\hline Ho1296 & B-177 & Tank & Not listed & 2/23/89 & M89413382 & $2 / 24 / 90$ & 8900125 & No & No & - & 4.1E-8 $\mathrm{uCl} / \mathrm{ml}$ & 1.1E.7 uCl/ml & No & A \\
\hline H02819 & 151 & Not listed & Not listed & $12 / 15 / 88$ & See comment & 2/2/89 & 8801545 & No & No & Placed on Req $\mathrm{H} 4633$ & No & No & No & $\mathbf{A}$ \\
\hline H02820 & 151 & Not listed & Not listed & $12 / 15 / 88$ & See comment & 2/2/89 & 8801547 & No & No & Put on Req H4638 & No & No & No & \\
\hline H02828 & 151 & Not listed & Not listed & $1 / 12 / 89$ & See comment & $1 / 17 / 89$ & Not listed & No & No & Put on Req $\mathrm{H} 4636$ & No & No & No & \\
\hline H04637 & 612 & NA & Not listed & $2 / 3 / 89$ & M89561609 & $2 / 13 / 90$ & None & No & No & Overpack of other waste & No & No & No & \\
\hline H04670 & 612 & NA & Not listed & $4 / 26 / 89$ & M89413242 & $8 / 8 / 89$ & None & No & No & Overpack & No & No & No & . \\
\hline H04845 & 361 & 1747 & Not listed & $8 / 3 / 89$ & See comment & Not listed & None & No & No & No manifest attached & No & No & No & \\
\hline Ho5000 & 298 & Not listed & Not listed & $10 / 12 / 89$ & M8913265 & $12 / 11 / 89$ & 8901190 & No & No & - & $1.5 \mathrm{E}-8 \mathrm{uCi} / \mathrm{ml}$ & $5.0 \mathrm{E}-8 \mathrm{uCi} / \mathrm{ml}$ & $2.9 \mathrm{E}-5 \mathrm{uCl} / \mathrm{ml}$ & A \\
\hline H05153 & 177 & Not listed & Not listed & $2 / 9 / 89$ & See comment & $10 / 26 / 89$ & 8801774 & No & No & Placed on Req H39080 & $1.1 \mathrm{E}-7 \mathrm{uCl} / \mathrm{ml}$ & 2.8E-7 uCl/ml & No & A \\
\hline H05154 & 177 & Not listed & Not listed & $2 / 9 / 89$ & See comment & 9/12/89 & 8801774 & No & No & Placed on Req H35100 & $1.1 \mathrm{E}-7 \mathrm{ucl} / \mathrm{ml}$ & 2.8E-7 uCl/ml & No & $\mathbf{A}$ \\
\hline H06723 & 332 & 1256 & Not listed & $1 / 11 / 90$ & AR278445 & $3 / 27 / 90$ & 8901159 & No & No & Ref. to Req H34343, went to AR278445 & $2.7 \mathrm{E}-3 \mathrm{uCl} / \mathrm{ml}$ & $1.2 \mathrm{E}-1 \mathrm{uCl} / \mathrm{ml}$ & No & A \\
\hline H06734 & 332 & Ret. tank 2 & Not listed & $1 / 9 / 89$ & M88610495 & $4 / 17 / 89$ & 8801795 & No & No & & $1.7 \mathrm{E}-8 \mathrm{uCl} / \mathrm{ml}$ & 2.5E-8 uCi/ml & $6.2 \mathrm{E}-6 \mathrm{uCl} / \mathrm{ml}$ & $\mathbf{A}$ \\
\hline H06743 & 332 & Basement & Not listed & 12/22/88 & See comment & $4 / 6 / 89$ & 8801371 & No & No & Placed on req 4670 & $2.8 \mathrm{E}-7 \mathrm{uCl} / \mathrm{mI}$ & 3.9E-7 $\mathrm{uCl} / \mathrm{ml}$ & No & 0 \\
\hline Ho6750 & 332 & 1313 & Not listed & $12 / 15 / 88$ & See comment & $3 / 10 / 89$ & 8801528 & No & No & Placed on req 8963 & 3.4E-6 uCl/mil & $1.8 \mathrm{e}-6 \mathrm{uCl} / \mathrm{ml}$ & No & $\mathbf{A}$ \\
\hline H08857 & 612 & NA & Not listed & $5 / 28 / 89$ & M89413246 & $8 / 10 / 89$ & None & No & No & Overpack & No & No & No & - \\
\hline Ho8859 & 612 & NA & Not listed & $5 / 28189$ & M89413246 & 8/10/89 & None & No & No & Overpacking of acids & No & No & No & - \\
\hline Hos878 & 612 & NA & Not listed & $5 / 26 / 89$ & M89413245 & $8 / 10 / 89$ & None & No & No & Overpack & No & No & No & . \\
\hline H09327 & 624 & Not listed & Unknown & $7 / 8 / 89$ & M89413265 & $12 / 11 / 89$ & 8901392 & No & Unknown & Drum of rain water & $1.7 \mathrm{E}-9 \mathrm{uCi} / \mathrm{ml}$ & $8.8 \mathrm{E} \cdot 9 \mathrm{uC \textrm {C } / \mathrm { ml }}$ & No & A \\
\hline H15971 & 141 & Not listed & Not listed & 6/8/89 & See comment & Not listed & 8900526 & No & No & Acid waste rinse water - put into Req 35029 & $2.2 \mathrm{E}-8 \mathrm{ucl} / \mathrm{ml}$ & $2.1 \mathrm{E}-7 \mathrm{uCl} / \mathrm{ml}$ & No & A \\
\hline H17385 & 514 & Not listed & Not listed & $1 / 25 / 89$ & M89561609 & $2 / 13 / 90$ & 8900006 & No & No & Placed on Req H4637, went to 89561609 & $1.2 \mathrm{E}-7 \mathrm{uCl} / \mathrm{ml}$ & $2.4 \mathrm{E}-6 \mathrm{uCl} / \mathrm{ml}$ & 3.1E-3 uCl/m1 & A \\
\hline H17386 & 514 & Not listed & Not listed & 11/30/88 & See comment & $2 / 2 / 89$ & 8801521 & No & No & Put into Req H4635 & $0.1 \mathrm{E}-7 \mathrm{uCl} / \mathrm{ml}$ & 9.6E-7 uCl/ml & $1.3 \mathrm{E}-4 \mathrm{uCl} / \mathrm{ml}$ & $\mathbf{A}$ \\
\hline H17386 & & & & & & 2/2/89 & 8801522 & No & No & Put into Req H4635 & 3.7E-6 uC1/ml & 4.4E-6 $\mathrm{uCl} / \mathrm{ml}$ & 5.4E-6 uC1/m1 & $\mathbf{A}$ \\
\hline H17386 & 514 & Not listed & Not listed & $1 / 25 / 89$ & See comment & $2 / 2 / 89$ & 8900006 & No & No & Put into Req $\mathrm{H} 4635$ & $1.2 \mathrm{E}-7 \mathrm{uCl} / \mathrm{ml}$ & 2.4E-6 uCl/ml & S.1E-3 $\mathrm{uCL} / \mathrm{ml}$ & A \\
\hline H17386 & & & & & & 2/2/89 & 8900007 & No & No & Put into Req H4635 & $1.4 \mathrm{E}-6 \mathrm{uCl} / \mathrm{ml}$ & $2.0 \mathrm{E}-6 \mathrm{uCl} / \mathrm{ml}$ & $1.2 \mathrm{E}-4 \mathrm{uCl} / \mathrm{ml}$ & A \\
\hline H19701 & 514 & Not listed & Not listed & $6 / 22 / 88$ & S 514SRV-1 & $6 / 22 / 88$ & 4581 & No & No & Released to sewer & $1.7 \mathrm{E}-8 \mathrm{uCj} / \mathrm{ml}$ & $2.8 \mathrm{E}-8 \mathrm{uC} \mathrm{i} / \mathrm{ml}$ & No & A \\
\hline H19805 & 514 & Not listed & Not listed & $12 / 23 / 88$ & M89413242 & $8 / 8 / 89$ & 8800922 & No & No & Placed on Req H4670, went to 89413242 & Not listed & Not listed & $2.9 \mathrm{E}-5 \mathrm{uct} / \mathrm{ml}$ & 0 \\
\hline H19807 & 514 & Not listed & Not listed & $12 / 23 / 88$ & See comment & $12 / 26 / 88$ & 8801332 & No & No & Placed on Req $\mathrm{H63635}$ & $1.1 \mathrm{E}-6 \mathrm{uCl} / \mathrm{ml}$ & $1.4 \mathrm{E} \cdot 6 \mathrm{uCi} / \mathrm{ml}$ & No & o \\
\hline H19808 & 514 & 120 & Not listed & $4 / 20 / 89$ & See comment & $5 / 17 / 89$ & 8900344 & No & No & Placed on Req H8857, went to 89413246 & $7.2 \mathrm{E}-8 \mathrm{uCl} / \mathrm{ml}$ & 3.3E-6 uCl/ml & $1.3 \mathrm{E}-6 \mathrm{uCj} / \mathrm{ml}$ & A \\
\hline H19809 & 514 & 120 & Not listed & $4 / 20 / 89$ & M89413246 & $8 / 10 / 89$ & 8900293 & No & No & Placed on Req H8859, went to 89413246 & ND & $4.2 \mathrm{E}-7 \mathrm{uCl} / \mathrm{ml}$ & $5.3 \mathrm{E}-7 \mathrm{uCi} / \mathrm{ml}$ & A \\
\hline H19810 & 514 & 120 & Not listed & $4 / 20 / 89$ & M89413246 & $8 / 10 / 89$ & 8900390 & No & No & Placed on Req H8859, went to 89413246 & $1.5 \mathrm{E}-6 \mathrm{uCl} / \mathrm{ml}$ & $2,5 \mathrm{E}-5 \mathrm{uCl} / \mathrm{ml}$ & $1.9 \mathrm{E}-4 \mathrm{uCl} / \mathrm{ml}$ & A \\
\hline H19811 & 514 & Not listed & Not listed & $12 / 12 / 88$ & M89561609 & $2 / 13 / 90$ & 8801671 & No & No & Placed on Req H4637, went to 89561609 & $5.0 \mathrm{E}-9 \mathrm{uC} \mathrm{C} / \mathrm{ml}$ & $1.4 \mathrm{E}-6 \mathrm{uCl} / \mathrm{ml}$ & 2.9E-5 uCt/ml & A \\
\hline H19812 & 514 & Not listed & Not listed & $12 / 12 / 88$ & M89561609 & $2 / 13 / 90$ & 8801670 & No & No & Put into Req 4637 , went to M89561609 & 1E-6 ucl $/ \mathrm{ml}$ & 4E- $6 \mathrm{uCl} / \mathrm{ml}$ & $1.4 \mathrm{E}-5 \mathrm{uCl} / \mathrm{ml}$ & $\mathbf{A}$ \\
\hline H19812 & & & & & & $2 / 13 / 90$ & 8801671 & No & No & Put into Req 4637, went to M89561609 & SE-9 uCl/ml & $1.4 \mathrm{E} \cdot 6 \mathrm{uCl} / \mathrm{ml}$ & $2.9 \mathrm{E}-\mathrm{5} \mathrm{uCl} / \mathrm{ml}$ & A \\
\hline
\end{tabular}



Table D-1. Spot checked H-Req data summary.

\begin{tabular}{|c|c|c|c|c|c|c|c|c|c|c|c|c|c|c|}
\hline \multicolumn{3}{|c|}{ Spot Checked from files } & & & & & & \multirow[b]{3}{*}{ Swipe/Survey } & \multirow[b]{3}{*}{ Process Knowl } & \multirow[b]{3}{*}{ Comments } & \multirow[b]{3}{*}{ Gross Alpha } & \multirow{3}{*}{$\begin{array}{c}\text { Radiological Analysis } \\
\text { Gross Beta } \\
\end{array}$} & & \multirow{2}{*}{$\begin{array}{l}\text { Aqueous, } \\
\text { Oil, solid, }\end{array}$} \\
\hline & & & & & & & & & & & & & & \\
\hline H-Req \# & Bldg \# & Room \# & RMMA? & H-Req Date & Manifest * & Manifest Date & Sample \# & & & & & & H.3 & sludge \\
\hline H19812 & & & & & & $2 / 13 / 90$ & 8801672 & No & No & Put into Req 4637, went to M89561609 & 3E-6 uct/m1 & $1.8 \mathrm{E}-4 \mathrm{uCl} / \mathrm{ml}$ & $1.1 \mathrm{E}-2 \mathrm{vCl} / \mathrm{ml}$ & A \\
\hline H19813 & 514 & Not listed & Not listed & $12 / 23 / 88$ & See comment & $10 / 18 / 89$ & 8801670 & No & No & Placed on Req H38365 & $1.0 \mathrm{E}-6 \mathrm{uCl} / \mathrm{ml}$ & $4.0 \mathrm{E}-6 \mathrm{uCl} / \mathrm{ml}$ & 1.4E-5 uCl/ml & $\mathbf{A}$ \\
\hline H19814 & 514 & Not listed & Not listed & $12 / 22 / 88$ & S 612 SRV-4 & $12 / 23 / 88$ & 8801673 & No & No & Released to sewer & $2.4 \mathrm{E}-8 \mathrm{uCl} / \mathrm{mal}$ & 4.8E-8 uCi/ml & 4.5E- $6 \mathrm{uCl} / \mathrm{ml}$ & $\mathbf{A}$ \\
\hline H19815 & 514 & Not listed & Not listed & $4 / 20 / 89$ & M89413246 & $8 / 10 / 89$ & 8900391 & No & No & Placed on Req H8859, went to 89413246 & $1.6 \mathrm{E}-6 \mathrm{uCl} / \mathrm{ml}$ & 2.5E-5 uCl/mi & $1.3 \mathrm{E}-4 \mathrm{uCl} / \mathrm{ml}$ & A \\
\hline H19816 & 514 & Not listed & Not listed & $5 / 17 / 89$ & See comment & 7/6/89 & 8900523 & No & No & Placed on Req $\mathrm{H} 23062$ & $7.8 \mathrm{E}-9 \mathrm{uCi} / \mathrm{ml}$ & 1.1E-6 uCl/mI & $7.4 \mathrm{E}-5 \mathrm{uCl} / \mathrm{ml}$ & A \\
\hline H19821 & 514 & Not listed & Not listed & 7/13/89 & S 514SRV-1 & $7 / 6 / 89$ & 8900756 & No & No & Released to sewer & $2.3 \mathrm{E}-10 \mathrm{uC} / \mathrm{ml}$ & $3.1 \mathrm{E}-9 \mathrm{uCl} / \mathrm{ml}$ & $2.7 \mathrm{E}-6 \mathrm{uCi} / \mathrm{ml}$ & A \\
\hline H19893 & 514 & Not listed & Not listed & $5 / 17789$ & See comment & $7 / 6 / 89$ & 8900522 & No & No & Placed on Req H23062 & $1.9 \mathrm{E}-8 \mathrm{uCi} / \mathrm{ml}$ & 9.2E-6 uCl/ml & 7.4E-5 uCl/ml & A \\
\hline H20439 & 141 & Tank & Not listed & $1 / 11 / 90$ & M89413326 & $8 / 29 / 89$ & 8910888 & No & No & Cross references H Req H20440 & No & No & No & A \\
\hline $\mathrm{H} 20440$ & 141 & Tank & Not listed & $1 / 4 / 90$ & M89413326 & $8 / 29 / 89$ & 8901645 & No & No & Cross references H Req H20439 & $3.8 \mathrm{E}-8 \mathrm{ucl} / \mathrm{ml}$ & $3.1 \mathrm{E}-8 \mathrm{uCi} / \mathrm{ml}$ & No & $\mathbf{A}$ \\
\hline $\mathrm{H} 22200$ & 212 & Outside & No & $3 / 11 / 92$ & M91760064 & $3 / 11 / 92$ & 198918 & No & No & Mineral oil, no rad data & No & No & No & 0 \\
\hline H23472 & 131 & Not listed & Not listed & $4 / 14 / 90$ & ILA128169 & $4 / 14 / 90$ & No & No & No & Labpack - numerous other regs attached & No & No & No & A \\
\hline H23473 & 131 & Not listed & Not listed & $4 / 14 / 90$ & 1L4128169 & $4 / 14 / 90$ & No & No & No & Labpack - numerous other reqs attached & No & No & No & $A$ \\
\hline $\mathrm{H} 23490$ & 341 & Not listed & Not listed & $4 / 12 / 90$ & M89930389 & $6 / 4 / 90$ & No & No & No & - & No & No & No & A \\
\hline H23518 & 612 & NA & Not listed & $12 / 14 / 89$ & M89413375 & $2 / 23 / 90$ & 9000068 & No & No & $R^{\prime}$ Req put in with this H Req & No & No & No & $\mathbf{s}$ \\
\hline $\mathrm{H} 23740$ & 511 & Not listed & Not listed & $8 / 16 / 90$ & M89930556 & $8 / 23 / 90$ & 9001439 & No & No & $\cdot$ & No & No & No & \\
\hline H25705 & 361 & 1745 & Not listed & $3 / 15 / 90$ & See comment & $3 / 28 / 90$ & No & No & No & Put on Req H57567 & No & No & No & A \\
\hline H25822 & 141 & Not listed & Not listed & $5 / 17 / 90$ & M89930393 & $6 / 6 / 90$ & $\mathbf{9 0 0 0 7 0 6}$ & No & No & No rad data & No & No & No & A \\
\hline H25998 & 888 & $843 \mathrm{C}$ & Not listed & 10/25/90 & Not listed & Not listed & 9001484 & $<300 \mathrm{dpm} / \mathrm{ml}$ & No & No rad data & No & No & No & $\mathbf{S I}, \mathbf{A}$ \\
\hline $\mathrm{H} 26000$ & 888 & 843 & Not listed & $10 / 25 / 90$ & Not listed & Not listed & 9001484 & $<300 \mathrm{dpm} / \mathrm{ml}$ & No & No rad data & No & No & No & A \\
\hline H26543 & $321 \mathrm{~A}$ & 1237 & No & 6/27/91 & M91760291 & $9 / 22 / 92$ & 9101254 & No & No & Discrepencies on RMMA status, etc. & 5.7E-8 uCi/ml & $<2.6 \mathrm{E}-8 \mathrm{uCi} / \mathrm{ml}$ & No & 0 \\
\hline H26543 & & & & & & & 9202188 & No & No & & ND & ND & ND & \\
\hline H27001 & 511 & Not listed & Not listed & $8 / 10 / 89$ & AR395954 & $8 / 22 / 89$ & Not listed & No & No & . & No & No & No & \\
\hline \multirow[t]{4}{*}{ H28411 } & 514 & Not listed & Not listed & $4 / 12 / 90$ & See comment & $6 / 1 / 90$ & 8901014 & No & No & Placed on Req H55289, see U, Pu, Am results & No & No & No & sl \\
\hline & & & & & & & & & & 1.1E-7 uCi/g U-238 & & & & \\
\hline & & & & & & & & & & 3.3E-7 uCi/g Pu-239/240 & & & & \\
\hline & & & & & & & & & & 1.7E-8 uCi/g Am-241/Pu-238 & & & & \\
\hline \multirow[t]{4}{*}{$\mathrm{H} 28412$} & 514 & Not listed & Not listed & $4 / 12 / 90$ & See comment & $6 / 1 / 90$ & 8901013 & No & No & Placed on Req H55289, see U, Pu, Am results & No & No & No & SI \\
\hline & & & & & & & & & & $3.9 \mathrm{E}-6 \mathrm{uci} / \mathrm{g} \mathrm{U}-238$ & & & & \\
\hline & & & & & & & & & & $2.3 \mathrm{E}-6 \mathrm{uCi} / \mathrm{g}$ Pu-239/240 & & & & \\
\hline & & & & & & & & & & $3.9 \mathrm{E}-7 \mathrm{uCi} \mathrm{g} \mathrm{Am}-241 / \mathrm{Pu} \cdot 238$ & & & & \\
\hline H28487 & 514 & Not listed & Not listed & $7 / 12 / 89$ & See comment & $7 / 12 / 89$ & 9100186 & No & No & No rad data, but turned to Req R019733 & see comment & see comment & see comment & \\
\hline H28489 & 514 & Tank & Not listed & 4/1/91 & B 91114 & $4 / 2 / 91$ & 9100358 & No & No & Not sure of " $\mathrm{B}$ " designation for deposition & $2.6 \mathrm{E}-8 \mathrm{uCl} / \mathrm{ml}$ & $7.0 \mathrm{E}-8 \mathrm{uCl} / \mathrm{ml}$ & 3.9E-5 uCl/mal & $\mathrm{A}, \mathrm{S}$ \\
\hline $\mathrm{H} 28490$ & 514 & Tank & Not listed & 4/1/91 & B91114 & 4/2/91 & 9100386 & No & No & Unsure of " $\mathrm{B}$ " manifest meaning & $1.3 \mathrm{E} \cdot 8 \mathrm{uCi} / \mathrm{ml}$ & $7.0 \mathrm{E}-8 \mathrm{uCl} / \mathrm{ml}$ & 1.5E-5 uCl/ml & S.A \\
\hline H28605 & 141 & Tank & Not listed & $1 / 11 / 90$ & See comment & $4 / 10 / 90$ & 8901645 & No & No & References H Reqgs H20439 and H204440 & No & No & No & \\
\hline H28671 & 141 & Not listed & Not listed & $1 / 11 / 90$ & M89413326 & $1 / 16 / 90$ & 8901755 & No & No & - & $2.2 \mathrm{E}-8 \mathrm{uCl} / \mathrm{ml}$ & $1.9 \mathrm{E}-8 \mathrm{uCi} / \mathrm{ml}$ & No & A \\
\hline H28742 & 251 & Not listed & Not listed & 9/27/90 & M90271782 & $1 / 2 / 91$ & 9001734 & No & No & . & ND & $1.0 \mathrm{E}-6 \mathrm{uci} / \mathrm{ml}$ & No & A \\
\hline H28743 & 251 & Not listed & Not listed & 9/27/90 & See comment & $10 / 8 / 90$ & 9001733 & No & No & Placed on Req H54314 & No & $3.3 \mathrm{E}-7 \mathrm{uCl} / \mathrm{ml}$ & No & A \\
\hline H28749 & 151 & Not listed & Not listed & $5 / 10 / 90$ & See comment & $5 / 18 / 90$ & 900229 & No & No & Placed on Req H5 4980 & No & No & No & o \\
\hline H30852 & 231 & 1100 & Not listed & 2/26/90 & M89930363 & $5 / 24490$ & 8901240 & No & No & - & $1.6 \mathrm{E}-7 \mathrm{uCl} / \mathrm{ml}$ & $1.0 \mathrm{E}-04 \mathrm{uCl} / \mathrm{ml}$ & No & $\mathbf{A}$ \\
\hline
\end{tabular}


Table D-1. Spot checked H-Req data summary.

\begin{tabular}{|c|c|c|c|c|c|c|c|c|c|c|c|c|c|c|}
\hline \multicolumn{3}{|c|}{ Spot Checked from files } & & & & & & & & & & & & Aqueous, \\
\hline & & & & & & & & & & & & Radiological Analygis & & Oil, solid, \\
\hline H-Req \# & Bldg\# \# & Room \# & RMMA? & H-Req Date & Manifest \#! & Manifest Date & Sample \# & Swipe/Survey & Process Knowl & Comments & Gross Alpha & Gross Beta & H-3 & sludge \\
\hline H30996 & 231 & Not listed & Not listed & Not listed & Not listed & Not listed & 9101887 & No & No & H Req not attached, but sample data is & ND & $\leq 3.8 \mathrm{E}-8 \mathrm{uCi} / \mathrm{ml}$ & $\begin{array}{c}\text { 3.8E-5 uCl/ml } \\
\text { No }\end{array}$ & A \\
\hline H31222 & 361 & 1745 & Yes & $2 / 14 / 91$ & M91760040 & $2 / 7 / 92$ & No & No & Yes & No rad data, based on Gen. knowledge & No & No & No & $\mathbf{A}$ \\
\hline H31225 & 361 & 1745 & Yes & $5 / 19 / 91$ & M91760054 & $2 / 28 / 92$ & $\mathrm{No}$ & No & Yes & No rad data, based on Gen. knowledge & No & No & No & $\mathbf{A}$ \\
\hline H40189 & 511 & Not listed & Yes & $4 / 25 / 91$ & B 92103 & $3 / 19 / 92$ & None & Swipe < bckd & Yes & Fluoresent lights & No & No & No & $\mathrm{s}$ \\
\hline H41055 & 531 & Not listed & Not listed & $4 / 3 / 91$ & M90271967 & 6/20/91 & No & Yes - $<$ bekgrd & No & - & No & No & No & A \\
\hline H44431 & 332 & Not listed & Not listed & $5 / 10 / 90$ & AR425188 & $7 / 3 / 90$ & Not listed & No & No & Placed on req 55017 & ND & Not listed & Not listed & \\
\hline H46142 & 332 & Not listed & Not listed & $8 / 26 / 91$ & S 612SRV-4 & 9/26/91 & 9101697 & No & No & Released to sewer, $* *$ data is total sol. \&liq. & $2.9 \mathrm{E}, \mathrm{Lel} / \mathrm{mi}$ & $9.5 \mathrm{E}-9 \mathrm{uCi} / \mathrm{ml}$ & $3.6 \mathrm{~V}-6 \mathrm{uc} / \mathrm{ml}$ & $A$ \\
\hline H48674 & $321 \mathrm{C}$ & E Yard & No & 11/29/90 & M90271772 & $12 / 12 / 90$ & 9001996 & No & No & Coolant - trimsol & $9.6 \mathrm{E}-8 \mathrm{uCl} / \mathrm{ml}$ & $1.4 \mathrm{E}-7 \mathrm{uCl} / \mathrm{ml}$ & No & $\mathbf{A}$ \\
\hline H48690 & $321 \mathrm{C}$ & Not listed & Not listed & $2 / 7 / 91$ & M90271891 & $4 / 5 / 91$ & 9002302 & No & No & Coolant wash water & $<7.3 \mathrm{E}-8 \mathrm{uCl} / \mathrm{ml}$ & 5.2E-7 uCi/ml & No & A \\
\hline H55227 & 612 & $\mathrm{NA}$ & Not listed & $5 / 23 / 90$ & M89930386 & $5 / 30 / 90$ & Not listed & No & No & Numerous H Reqg listed, part of overpack & No & No & No & \\
\hline $\mathrm{H} 62807$ & 361 & 1342 & Yes & $2 / 28 / 91$ & M91760025 & $1 / 24 / 92$ & Not listed & No. & Yes & Aqueous solution, no rad data & No & No & No & $\mathbf{A}$ \\
\hline H70086 & 175 & Not listed & Not listed & $6 / 13 / 91$ & S612SRV-4 & 9/19/91 & $\mathbf{9 1 0 0 7 9 7}$ & No. & No & Released to sewer & $<3.5 \mathrm{E}-9 \mathrm{uC} \mathrm{C} / \mathrm{ml}$ & $<9.4 \mathrm{E}-9 \mathrm{uC} \mathrm{d} / \mathrm{ml}$ & $5.5 \mathrm{E}-7 \mathrm{uCi} / \mathrm{ml}$ & $\mathrm{A}$ \\
\hline Not listed & 322 & E Yard & Not listed & Not listed & Not listed & Not listed & 8901210 & No & No & No req attached & $<2.7 \mathrm{E}-7 \mathrm{uCl} / \mathrm{ml}$ & $<2.4 \mathrm{E}-7 \mathrm{uCl} / \mathrm{ml}$ & No & $\mathbf{A}$ \\
\hline \multirow{2}{*}{ Not listed } & & & & & & & & & & & & & $6.3 \mathrm{E}-5 \mathrm{uCl} / \mathrm{ml}$ & \\
\hline & & & & & & & & & & & Key: & Before moritortum & Prter moittorium & \\
\hline
\end{tabular}


Table D-2. Random H-Req data summary

\begin{tabular}{|c|c|c|c|c|c|c|c|c|c|c|c|c|c|c|}
\hline & & & & & & & & & & & & Radiological Analygis & & Aqueous, oil \\
\hline H-Req \# & Bldg \# & Room * & RMMA? & H-Req Date & Manifest * & Manifest Date & Sample: & Swipe/Survey Data & Process Knowled & Comments & Gross Alpha & Gross Beta & $\mathrm{H}-3$ & solid, sludge \\
\hline & & & & & & & & & & & & & & \\
\hline H6758 & 332 & Not listed & Not listed & $3 / 2290$ & See comment & Not listed & $\mathbf{N}_{0}$ & No & No & Waste from vac. pump - put into Req 51368 & No & No & No & $s, 0$ \\
\hline H8831 & 151 & Not listed & Not listed & 9/28/89 & M91760005 & $1 / 7 / 92$ & No & Screening form & No & No Bcreening levels listed beside bckd level & No & No & No & $\mathrm{s}$ \\
\hline H9308 & 612 & $\mathrm{NA}$ & NA & $7 / 3 / 89$ & M89413243 & 8/8/89 & $\mathrm{NA}$ & No & Unknown & Contains several sub Regs & No & No & No & $A$ \\
\hline H10452 & 332 & Not listed & Not listed & $3 / 24 / 90$ & See comment & Not listed & No & No & No & (leaded glass) Put into Req 51368 & No & No & No & $\mathbf{s}$ \\
\hline H12405 & 241 & Not listed & Not listed & $9 / 14 / 89$ & M91760005 & $1 / 792$ & No & No & No & Lab Waste & No & No & No & Sl, A \\
\hline H14042 & 322 & Not listed & Not listed & 12/21/89 & M89413395 & $3 / 13 / 90$ & 8901210 & No & No & Reqs H14043-H14048 put on this req & 2.7E-7 uCi/mL & 2.4E-7 uCt/ml & No & A \\
\hline H20811 & 175 & Not listed & Not listed & $3 / 22 / 90$ & See comment & Not listed & No & No & No & Mechanical pump oil - put into Req 51368 & No & No & No & o \\
\hline H23230 & 391-W & Not listed & Not listed & $3 / 2290$ & See comment & Not listed & No & No & No & Ethyl Ale. $5 \mathrm{gal}$ empty can - put into Req 51368 & No & No & No & A \\
\hline H24081 & 490 & Not listed & Not listed & 3/24/90 & See comment & Not listed & $\mathrm{No}_{0}$ & No & No & Oil soaked ragg - put into Req 51368 & $\mathrm{No}$ & No & No & $\mathrm{s}, 0$ \\
\hline H25103 & 361 & 1664 & Not listed & 7/30/89 & M89930279 & $4 / 12 / 90$ & No & No & No & Cleanup of spill waste & No & No & No & $s$ \\
\hline H25357 & 113 & Not listed & Not listed & $12 / 13 / 90$ & See comment & Not listed & $\mathrm{NA}$ & No & Unknown & Sent for silver recovery, put into $\mathrm{H63908}$ & No & No & No & A \\
\hline H28227 & 222 & Exterior & Not listed & Not listed & M89930254 & $4 / 4 / 90$ & 8901306 & No & No & No req forms, numerous reqs listed on resulte & $5.0 \mathrm{E}-06 \mathrm{uCl} / \mathrm{g}$ & $1.5 \mathrm{E}-05 \mathrm{uCl} / \mathrm{g}$ & No & st \\
\hline H28228 & 222 & Exterior & Not listed & Not listed & M89930254 & $4 / 4 / 90$ & 8901306 & No & No & No req forms, numerous reqs listed on results & $5.0 \mathrm{E}-06 \mathrm{uCl} / \mathrm{g}$ & $1.5 \mathrm{E}-05 \mathrm{uCl} / \mathrm{g}$ & No & sl \\
\hline H28229 & 222 & Exterior & Not listed & Not listed & M89930254 & $4 / 4 / 90$ & 8901306 & No & No & No req forms, numerous reqs listed on results & 5.0E-06 uCl/g & 1.5E-05 uCl/g & No & $\mathrm{SI}$ \\
\hline H28230 & 222 & Exterior & Not listed & Not listed & M89930254 & $4 / 4 / 90$ & 8901306 & No & No & No req forms, numerous reqs listed on resulte & $5.0 \mathrm{E}-06 \mathrm{uCl} / \mathrm{g}$ & $1.5 \mathrm{E}-05 \mathrm{uCl} / \mathrm{g}$ & No & SI \\
\hline H28231 & 222 & Exterior & Not listed & Not listed & M89930254 & $4 / 4 / 90$ & 8901306 & No & No & No req forms, numerous regs listed on results & $5.0 \mathrm{E}-06 \mathrm{uCl} / \mathrm{g}$ & $1.5 \mathrm{E}-05 \mathrm{uCl} / \mathrm{g}$ & No & sl \\
\hline H28232 & 222 & Exterior & Not listed & Not listed & M89930254 & $4 / 4 / 90$ & 8901306 & No & No & No req forms, numerous reqs listed on results & 5.0E-06 uCl/g & $1.5 \mathrm{E}-05 \mathrm{uCl} / \mathrm{g}$ & No & Sl \\
\hline H28233 & 222 & Exterior & Not listed & Not listed & M89930254 & $4 / 4 / 90$ & 8901306 & No & No & No req forms, numerous reqs listed on results & $5.0 \mathrm{E}-06 \mathrm{uCl} / \mathrm{g}$ & $1.5 \mathrm{E}-05 \mathrm{uCl} / \mathrm{g}$ & No & Sl \\
\hline H28234 & 222 & Exterior & Not listed & Not listed & M89930254 & $1 / 4 / 90$ & 8901306 & No & No & No req forms, pumerous requ listed on results & 5.0E-06 uCl/g & $1.5 \mathrm{E}-05 \mathrm{uCl} / \mathrm{g}$ & No & $\mathrm{Sl}$ \\
\hline H28235 & 222 & Exterior & Not listed & Not listed & M89930254 & $4 / 4 / 90$ & 8901306 & No & No & No req forms, numerous reqs listed on resulta & 5.0E-06 uCl/g & 1.5E-05 uCi/g & No & $\mathrm{Si}$ \\
\hline H28434 & 514 & Not listed & Not listed & $8 / 2290$ & M90895294 & 8/16/91 & 9101425 & No & No & Kodak silver recovery (data not attached) & ND & ND & ND & $s$ \\
\hline H31531 & 366 & Not listed & Not listed & $3 / 29 / 90$ & M89930254 & $4 / 4 / 90$ & $\mathrm{NA}$ & No & No & Part of lab pack, medical waste & No & No & No & $\mathbf{s}$ \\
\hline H33181 & 322 & Not listed & Not listed & $8 / 290$ & AR461921 & $11 / 2 / 90$ & 9001060 & No & No & Cross-referenced to H45030 & $3.6 \mathrm{E}-7 \mathrm{uCi} / \mathrm{g}$ & $4.5 \mathrm{E}-6 \mathrm{uCl} / \mathrm{g}$ & No & s \\
\hline H45900 & 251 & Not listed & Not listed & $12 / 20 / 90$ & M90271799 & $1 / 14 / 91$ & 9002024 & No & Unknown & Included into Req 68908 for disposition & $6 \mathrm{E}-8 \mathrm{uCi} / \mathrm{ml}$ & $2.5 \mathrm{E}-6 \mathrm{uCl} / \mathrm{ml}$ & No & 0 \\
\hline $\mathrm{H} 48458$ & 235 & 1100 & Yes & $8 / 1 / 91$ & M91760105 & $4 / 3 / 92$ & NA. & No & $Y_{\text {es }}$ & RMMAN Non-RMMA decl. & No & No & No & $\mathbf{s}$ \\
\hline H49908 & 222 & $1520 \mathrm{~B}$ & Yes & $4 / 4 / 91$ & M91760107 & $4 / 3 / 92$ & $\mathrm{NA}$ & No & Yes & RMMA/Non-RMMA decl. & No & No & No & $\mathrm{S}, \mathrm{A}$ \\
\hline H49908 & & & & & M90895389 & $4 / 1 / 92$ & & & & & & & & \\
\hline H51368 & 612 & NA & $\mathrm{NA}$ & 3/20/90 & 89930234 & 4/4/90 & $\mathrm{NA}$ & No & Unknown & Contained $>100$ sub Regs & No & No & No & $\mathbf{s}$ \\
\hline H55497 & 612 & NA & NA & $6 / 8 / 90$ & Not listed & Not listed & No & No & Unknown & Over pack of lab packs & No & No & No & A \\
\hline H59861 & 222 & Exterior & Not listed & Not listed & M89930254 & $4 / 4 / 90$ & 8901306 & No & No & No req forms, numerous reqs listed on results & 5.0E-06 uCi/s & $1.6 \mathrm{E}-05 \mathrm{uCl} / \mathrm{g}$ & No & sl \\
\hline H59862 & 222 & Exterior & Not listed & Not listed & M89930254 & $4 / 490$ & 8901306 & No & No & No req forms, numerous reqs listed on results & $5.0 \mathrm{E}-06 \mathrm{uCl} / \mathrm{g}$ & $1.5 \mathrm{E}-05 \mathrm{uCl} / \mathrm{g}$ & No & sl \\
\hline H59863 & 222 & Exterior & Not listed & Not listed & M89930254 & $4 / 4 / 90$ & 8901306 & No & No & No req forms, numerous reqs listed on resulta & $5.0 \mathrm{E}-06 \mathrm{uCl} / \mathrm{g}$ & $1.5 \mathrm{E}-05 \mathrm{uCl} / \mathrm{g}$ & No & st \\
\hline H59864 & 222 & Exterior & Not listed & Not listed & M89930254 & $4 / 4 / 90$ & 8901306 & No & No & No req forms, numerous reqs listed on results & $5.0 E-06 \mathrm{uCl} / \mathrm{g}$ & $1.5 \mathrm{E}-05 \mathrm{uCt} / \mathrm{g}$ & No & Sl \\
\hline H59872 & 222 & Exterior & Not listed & Not listed & M89930254 & $4 / 4 / 90$ & 8901306 & No & No & No req forms, numerous reqs listed on results & $5.0 \mathrm{E}-06 \mathrm{uCl} / \mathrm{s}$ & $1.5 \mathrm{E}-05 \mathrm{uCl} / \mathrm{g}$ & No & si \\
\hline H59873 & 222 & Exterior & Not listed & Not listed & M89930254 & $4 / 4 / 90$ & 8901306 & No & No & No req forms, numerous reqs listed on results & $5.0 \mathrm{E}-06 \mathrm{uCi} / \mathrm{g}$ & $1.5 \mathrm{E}-05 \mathrm{uCl} / \mathrm{g}$ & No & si \\
\hline H59874 & 222 & Exterior & Not listed & Not listed & M89930254 & $4 / 4 / 90$ & 8901306 & No & No & No req forms, numerous reqs listed on results & $5.0 \mathrm{e}-06 \mathrm{uCl} / \mathrm{g}$ & $1.5 \mathrm{E}-05 \mathrm{uCt} / \mathrm{g}$ & No & sl \\
\hline H58875 & 222 & Exterior & Not listed & Not listed & M89930254 & $4 / 4 / 90$ & 8901306 & No & No & No req forms, numerous regs listed on results & $5.0 \mathrm{E}-06 \mathrm{uCl} / \mathrm{g}$ & 1.5E-05 uCi/g & No & sl \\
\hline H59876 & 222 & Exterior & Not listed & Not listed & M89930254 & $4 / 4 / 90$ & 8901306 & No & No & No req forms, numerous reqs listed on results & $5.0 \mathrm{E}-06 \mathrm{uCl} / \mathrm{g}$ & $1.6 \mathrm{E}-05 \mathrm{uCl} / \mathrm{g}$ & No & sl \\
\hline H60911 & 612 & Not listed & Not listed & $1 / 7 / 91$ & M91760005 & $1 / 7 / 92$ & $\mathrm{NA}$ & No & No & Misc. liquids into labpacks & No & No & No & A \\
\hline H63659 & 612 & NA & NA & $11 / 5 / 90$ & MAR461962 & 10/4/91 & NA & No & Unknown & Over pack of chemicals & No & No & No & $s$ \\
\hline H63851 & 612 & $\mathrm{NA}$ & $\mathrm{NA}$ & $1 / 7 / 91$ & M91760005 & $1 / 7 / 92$ & No & No & No & Over pack of lab packs (from H39432) & No & No & No & $\mathbf{A}$ \\
\hline
\end{tabular}


Table D-2. Random H-Req data summary

\begin{tabular}{|c|c|c|c|c|c|c|c|c|c|c|c|c|c|c|}
\hline & & & & & & & & & & & & Radiological Analygis & & Aqueous, oil \\
\hline H-Req \# & Bldg \# & Room \# & RMMA? & H-Req Date & Manifest \# & Manifest Date & Sample * & Swipe/Survey Data & Process Knowled & Comments & Gross Alpha & Grogs Beta & H-3 & solid, sludge \\
\hline H63908 & 612 & $\mathrm{NA}$ & $\mathrm{NA}$ & 1/8/91 & M90271803 & $1 / 15 / 91$ & $\mathrm{NA}$ & No & Unknown & Contains several sub Reqs (overpack) & No & No & No & $\mathrm{s}$ \\
\hline H63914 & 612 & NA & $\mathrm{NA}$ & $1 / 14 / 91$ & M90271799 & $1 / 14 / 91$ & NA & No & Unknown & Contains several sub Reqs (overpack) & No & No & No & s \\
\hline $\mathrm{H} 64092$ & 612 & Not listed & Not listed & $8 / 17 / 90$ & M90895298 & $8 / 15 / 91$ & $\mathrm{NA}$ & Swipe data (see Req & No & Misc, size batteries into lab packs & No & No & No & $S, A$ \\
\hline H69714 & 361 & 1845 & No & $5 / 23 / 91$ & M91760105 & $4 / 3 / 92$ & $\mathrm{NA}$ & No & Yes & RMMANNon-RMMA decl. & No & No & No & $\mathbf{s}$ \\
\hline & & & & & & & & & & & & & & \\
\hline & & & & & & & & & & & & & & \\
\hline & & & & & & & & & & & \multicolumn{3}{|c|}{ Key: Before Moritorium } & \\
\hline
\end{tabular}




\begin{tabular}{|c|c|c|c|c|c|c|c|c|c|c|c|c|c|c|}
\hline & \multicolumn{2}{|c|}{ Biased H-Reqs } & & & & & & & & & & Radiological Analysis & & \\
\hline & & & & & & & & & & & & & & Aqueous, oil \\
\hline H.Req & Bldg \# & Room \# & RMMA? & H-Req Date & Manifest \# & Manifest Date & Sample * & Swipe/Survey Data & Process Knowledge & Comments & Gross Alpha & Gross Beta & $\mathrm{H}-3$ & solld, sludge \\
\hline H2820 & 151 & Not listed & Not listed & 12/15/88 & See comment & $2 / 2 / 89$ & 8801547 & No & No & Put on $\mathrm{H}-\mathrm{Req} \mathrm{H} 4638$ for disposition & No & No & No & $A$ \\
\hline H2828 & 151 & Not listed & Not listed & $\mathrm{N} / 2 / 89$ & See comment & $y / 17 / 89$ & None & No & No & Put on H-Req H4636 for disposition & No & No & No & $A$ \\
\hline H6708 & 332 & Ret. tank 2 & Not listed & 6/30/88 & M87250869 & $7 / 21 / 88$ & 8804157 & No & No & . & 6.72-8 $\times \mathrm{Cl} / \mathrm{ml}$ & 5.0E-8 uCi/ml & $2.8 \mathrm{E}-6 \mathrm{0C \textrm {Cl } / \mathrm { mil }}$ & A \\
\hline 16728 & 332 & Ret. tank 1 & Not listed & 2/23/89 & M87250967 & $3 / 3 / 89$ & 8801665 & No & No & - & $1.3 \mathrm{E}-8 \mathrm{uCL} / \mathrm{ml}$ & $4.72-7 \mathrm{ucl} / \mathrm{ml}$ & $5.92-6 \mathrm{mcl} / \mathrm{ml}$ & $A$ \\
\hline H6741 & 332 & Ret. tank 1 & Not listed & 2/23/89 & M87250967 & $3 / 3 / 89$ & 8801665 & No & No & . & $1.3 \mathrm{E}-8 \times \mathrm{Ct} / \mathrm{ml}$ & $4.78 .7 \mathrm{ucl} / \mathrm{ml}$ & B.9E-6 $\mathrm{wCl} / \mathrm{ml}$ & $A$ \\
\hline H6903 & 419 & Not listed & Not listed & 7/22/88 & M87250898 & $10 / 19 / 88$ & $\mathrm{NA}$ & No & No rad in waste & HWM Tag attached & No & No & No & $\mathbf{s}$ \\
\hline H6963 & 419 & Not listed & Not listed & 5/14/89 & M88610723 & $6 / 1 / 80$ & 8801390 & No & Not listed & $\therefore$ & $1.6 \mathrm{E}-6 \mathrm{uCl} / \mathrm{mml}$ & $2.2 \mathrm{E}-6 \mathrm{wCl} / \mathrm{ml}$ & No & A \\
\hline H6964 & 419 & Not listed & Not listed & $5 / 488$ & M88610723 & $6 / 1789$ & 8801390 & No & Not listed & - & $1.6 \mathrm{E}-6 \mathrm{mCl} / \mathrm{ml}$ & $2.2 \mathrm{E}-6 \mathrm{nCl} / \mathrm{ml}$ & No & A \\
\hline H6968 & 419 & Not listed & Not listed & $6 / 29 / 89$ & M89413293 & 10/9/89: & 8900662 & No & Unknown & 55 gal. drum of liq. waste & $2.8 \mathrm{E}-9 \mathrm{uCi} / \mathrm{ml}$ & ND & No & A \\
\hline H15180 & 332 & Ret. tank & Not listed & «119/89 & M89413273 & $11 / 22 / 89$ & 8901134 & No & No & - & $6.6 \mathrm{E}-9 \mathrm{uCl} / \mathrm{ml}$ & $3.2 \mathrm{E}-7 \mathrm{uCl} / \mathrm{ml}$ & 5E-7 uCiml & A \\
\hline H17338s & 514 & Not listed & Not listed & $125 / 89$ & See comment & $2 / 2 / 89$ & 8900007 & No & No & Put on H-Req H4634 for disposition & $1,4 \mathrm{E}-6 \mathrm{uCl} / \mathrm{ml}$ & $2.0 \mathrm{E}-6 \mathrm{nCl} / \mathrm{ml}$ & $1.2 \mathrm{E}-4 \mathrm{nCl} / \mathrm{ml}$ & A \\
\hline H19803 & 514 & Tank & Not listed & $4 / 1789$ & S 514SRV.2 & $5 / 1 / 189$ & 8900345 & No & No & Released to gewer & $1.7 \mathrm{E}-8 \mathrm{uCC} / \mathrm{ml}$ & $6.0 \mathrm{E}-8 \mathrm{uC} \mathrm{ml} \mathrm{mI}$ & $2.2 \mathrm{E}-6 \mathrm{uCl} / \mathrm{ml}$ & A \\
\hline H19804 & 514 & 120 & Not listed & ע/22/88 & See comment & $4 / 20 / 89$ & 8801743 & No & No & Placed on Req H8878, went to 89413245 & $3.4 \mathrm{k}-6 \mathrm{ncl} / \mathrm{ml}$ & .8.8E-6 vCl/ml & $1.0 \mathrm{E}-4 \mathrm{uCl} / \mathrm{ml}$ & A \\
\hline H19819 & 514 & Not listod & Not listed & 10/1289 & M89413286 & $11 / 6 / 89$ & 8900672 & No & No & - & $1.9 \mathrm{E}-8 \mathrm{uCi} / \mathrm{ml}$ & $1.3 \mathrm{E}-8 \mathrm{uC} / \mathrm{ml}$ & 2.12-4 uCl/ml & A \\
\hline H22129 & 419 & Not listed & No & $1 / 2491$ & M90895339 & 10/30/91 & $\mathrm{NA}$ & No & Empty Batteries & Moritorium sheet attached & No & No & No & $\mathrm{s}$ \\
\hline H22186 & 419 & Not listed & Not listed & 12/20/90 & M90271966 & 6/20/91 & 8002327 & No & Battery acid & No rad anal. requested & No & No & No & A \\
\hline H22754 & 514 & Not listed & Not listed & $12 \pi / 89$ & M89413262 & $12 / 11 / 89$ & 8901287 & No & No & Units for rad not clear on $\mathrm{H}$ Req & see comment & see comment & see comment & \\
\hline H22755 & 514 & Not listed & Not listed & $127 / 89$ & M89413262 & 12/11/89 & 8901287 & No & No & Only gives total currie content, no conc. & See comment & See comment & ND & A \\
\hline H26133 & 331 & Not listed & Yes & $1 / 2494$ & M91760025 & 1/24/92 & 9102552 & Unknown & Unknown & Rad added to waste & ND & ND & $2,62-6 \mathrm{ucl} / \mathrm{mm}$ & A \\
\hline H26133 & & & & & M90271913 & Not listed & & & & & & & & \\
\hline H26140 & 331 & Yard & Yes & $3 / 2191$ & MAR517595 & $2 / 14 / 92$ & $\mathrm{NA}$ & No & Unknown & Cert. Form & No & No & No & $\mathbf{A}$ \\
\hline H26161 & 331 & Not listed & Yes & 4/491 & M91760025 & $1 / 24 / 92$ & I1301 & Yes (unattached) & Unknown & Det. non rad & Yes (1 b\&g, 1 H-3) not a & & & \\
\hline H26175 & 331 & 154 & Yes & $3 / 21 / 91$ & M91760049 & $2 / 21 / 92$ & $\mathrm{NA}$ & No & No rad in waste & Cert. Form & No & No & No & $\mathbf{s}$ \\
\hline H44443 & 332 & Not listed & Not listed & $7 / 1290$ & Not listed & Not listed & 9001291 & No & No & Several reqs bulked. No manifest or req listed & ND & No & No & A \\
\hline H46126 & 332 & 1369 & Yes & 11/21/91 & M92258846 & 10/27982 & Swipe only & Swipe (cbckd) & No & . & ND (Swipe data) & $8.3 \mathrm{E}-3 \mathrm{dpm} / \mathrm{cm} 2$ (swipe & $8.6 \mathrm{E}-2 \mathrm{dpm} / \mathrm{cm} 2$ (swipe) & \\
\hline $\mathrm{H} 46143$ & 332 & 1321/1329 & Yes & 10/10/191 & See comment & Not listed & None & No & No & No manifest, sample data included with Req & No & No & No & \\
\hline $\mathrm{H62222}$ & 331 & Unknown & Unknown & Unknown & ILA128151 & 4/14/90 & $\mathrm{NA}$ & No & & Lab Pack & No & No & No & A \\
\hline H69411 & 5148 & 105 & Yes & 9/1191 & 90895373 & 12/1/1/21 & 9101579 & No & No & - & $466 \%, 4 \mathrm{~cm}$ & $18+2 \times 640 y / 21$ & ND & A \\
\hline H70085 & 514 & Not listed & Not listed & 8/4/88 & M90271926 & $425 / 91$ & 9100147 & No & No & . & 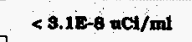 & $<3.4 \mathrm{E}-8 \mathrm{uCC} / \mathrm{ml}$ & 8.8E-5 uct/ml & A \\
\hline & & & & & & & & & & & & & & \\
\hline & & & & & & & & & & & Key: & o morttortum & Wur mooftortim & \\
\hline
\end{tabular}


APPENDIX E

H-Req Waste Designation 


\section{DOE-HQ Moratorium Definitions}

The DOE-HQ moratorium data request asked the DOE sites to categorize the waste shipments as known radioactive, clean, likely radioactive, or likely clean using the criteria in the following subsections. The data request provided guidance for assigning these categories. The process for classifying these wastes is illustrated in Figure E-1.

\section{Radioactive Waste}

Radioactive waste is any waste with radioactivity that was added to the volume or bulk of the waste as a result of DOE operations, as indicated by (a) material use history (i.e., use in a radioactive system or radioactive spill recovery), (b) sampling and analysis results showing radioactivity above background (background includes natural levels of radiation in materials), or (c) waste that has excessive surface contamination due to DOE operations as shown by surface survey results. Waste known to be potentially radioactively contaminated through material use history must be sampled to determine the activity content of the sample. Many wastes have no potential for being internally contaminated by radioactivity, but are present in radioactive materials management areas (RMMAs) where the potential for external contamination is present. For these wastes, a surface contamination survey must be performed, with results compared to surface contamination limits in DOE Order 5400.5. DOE-HQ has defined a nonradioactive waste as a waste that meets the following conditions (DOE 1993):

- The waste contains no added radioactivity (at a 95\% confidence level above background) in volume or bulk resulting from DOE operations [except wastes specifically exempted by the U.S. Environmental Protection Agency (EPA), DOE, or Nuclear Regulatory Commission (NRC) regulations]

- The waste has no surface radioactivity above limits established in DOE Orders or guidance [e.g., surface contamination limits and requirements of DOE Order 5400.5, II.5.c.(1)].

\section{Clean Waste}

Many DOE operations do not occur in an RMMA or have the potential for adding radioactive contamination to waste material. Clean waste is waste that originates outside an RMMA and has surface contamination levels less than DOE Order 5400.5 guidelines. The classification of clean waste can be broadened to include wastes that originate within an RMMA if these wastes can be verified clean by documented evidence of administrative controls, process knowledge, or sampling and analysis results showing no activity above background levels. Sampling and analysis results, and/or survey results, or administrative and material history documentation is required to characterize a waste as radioactive or clean. 



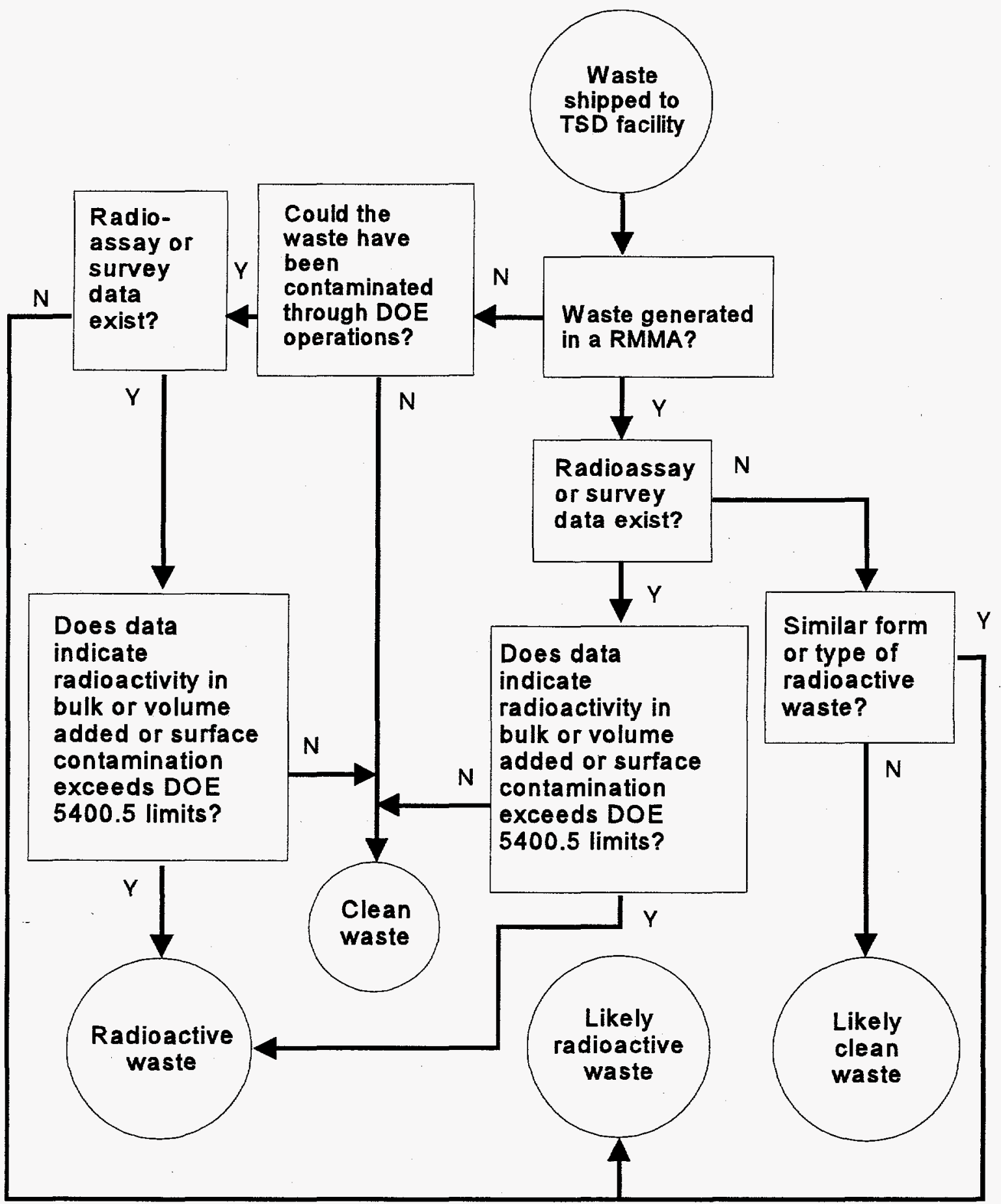

Figure E-1. DOE waste classification decision tree. 


\section{Likely Radioactive Waste}

Likely radioactive wastes are wastes shipped from LLNL that have limited retrievable documentation of sampling and analysis, survey results, administrative control, or material history documentation to enable classification of the waste as either known radioactive or clean. Wastes classified as likely radioactive waste are wastes that are similar in form/type and originate from the same process/area as wastes classified as known radioactive. Wastes classified as likely radioactive wastes imply a DOE operation may have added radioactivity to the volume or bulk of the waste or that surface contamination levels may exceed DOE Order 5400.5 guidelines.

\section{Likely Clean Waste}

Similar to likely radioactive waste, likely clean waste is waste originating from an RMMA and similar in form/type and origin as wastes classified as clean. For these wastes, documented evidence of administrative controls, process knowledge, or analytical data are not available to show DOE operations added no radioactivity to the waste bulk or volume, nor does evidence exists to verify the surface contamination is less than DOE Order 5400.5 guidelines. 
Table E-1. Spot checked H-requisition waste designation.

\begin{tabular}{|c|c|c|c|c|c|c|c|}
\hline \multicolumn{8}{|c|}{ Spot-check Reqs } \\
\hline H-Req & Manifest & RMMA & Manifest Date & $\begin{array}{c}\text { Known } \\
\text { Radioactive }\end{array}$ & Clean Waste & $\begin{array}{c}\text { Likely } \\
\text { Radioactive }\end{array}$ & Likely Clean \\
\hline $\mathrm{H} 2820$ & H4638 & Yes & $12 / 15 / 88$ & & & $\mathrm{X}($ To TSD? $)$ & \\
\hline H2828 & H4636 & Yes & $1 / 12 / 89$ & & & $\mathrm{X}$ (To TSD?) & \\
\hline H6703 & 87250869 & Yes & $7 / 21 / 88$ & $X$ & & & \\
\hline H6728 & 87250967 & Yes & $3 / 3 / 89$ & $\mathrm{X}$ & & & \\
\hline H6741 & 87250967 & Yes & $3 / 3 / 89$ & $\mathrm{X}$ & & & \\
\hline H6903 & 87250898 & Yes & $10 / 19 / 88$ & & $\mathrm{X}$ & & \\
\hline H6963 & 88610723 & Yes & $6 / 1 / 89$ & $X$ & & & \\
\hline H6964 & 88610723 & Yes & $6 / 1 / 89$ & $X$ & & & \\
\hline H6968 & 89413293 & Yes & $10 / 9 / 89$ & & $\bar{X}$ & & \\
\hline H15180 & 89413273 & Yes & $11 / 22 / 89$ & $\mathrm{X}$ & & & \\
\hline H17388 & H4634 & Yes & $2 / 2 / 89$ & X(To TSD?) & & & \\
\hline $\mathrm{H} 19803$ & S 514SRV-2 & Yes & $5 / 1 / 89$ & & $\mathrm{X}$ & & \\
\hline H19804 & 89413245 & Yes & $8 / 10 / 89$ & $X$ & & & \\
\hline H19819 & 89413286 & Yes & $11 / 6 / 89$ & $\mathrm{X}$ & & & \\
\hline $\mathrm{H} 22129$ & 90895339 & Yes & $10 / 30 / 91$ & & & & $X$ \\
\hline H22186 & 90271966 & Yes & $6 / 20 / 91$ & & & & $\bar{x}$ \\
\hline H22754 & 89413262 & Yes & $12 / 11 / 89$ & $\bar{x}$ & & & \\
\hline $\mathrm{H} 22755$ & 89413262 & Yes & $12 / 11 / 89$ & $x$ & & & \\
\hline H26133 & 91760025 & Yes & $1 / 24 / 92$ & $\mathrm{X}$ (To TSD?) & & & \\
\hline $\mathrm{H} 26140$ & AR517595 & Yes & $2 / 14 / 92$ & & & & $X$ \\
\hline $\mathrm{H} 26161$ & 91760025 & Yes & $1 / 24 / 92$ & & $\mathrm{X}$ & & \\
\hline $\mathrm{H} 26175$ & 91760049 & Yes & & & & & $\mathrm{X}$ \\
\hline H44443 & Not listed & Yes & Not listed & & & & $\mathrm{X}$ (To TSD?) \\
\hline H46126 & 92258846 & Yes & $10 / 27 / 92$ & & $X$ & & \\
\hline H46143 & Not listed & No (room) & Not listed & & & & $\mathrm{X}$ (To TSD?) \\
\hline H62222 & IL4128151 & Yes & $4 / 14 / 90$ & & & & $\mathrm{X}$ \\
\hline H69411 & 90895373 & Yes & $12 / 16 / 91$ & $\mathrm{X}$ & & & \\
\hline H70085 & U H70012 & Yes & $8 / 24 / 91$ & $X$ (To TSD?) & & & \\
\hline H517 & 87250958 & No & $1 / 31 / 89$ & & $\mathrm{X}$ & & \\
\hline H518 & 87250967 & No & $3 / 3 / 89$ & & $\mathrm{X}$ & & \\
\hline H530 & $\mathrm{H} 4692$ & No & $2 / 21 / 89$ & X (To TSD?) & & & \\
\hline H559 & 87250967 & Yes & $3 / 3 / 89$ & & $X$ & & \\
\hline H568 & 88610723 & Yes (612) & $6 / 1 / 89$ & & & & $\mathrm{X}$ \\
\hline $\mathrm{H} 1296$ & 89913382 & Yes & $2 / 24 / 90$ & $\mathrm{X}$ & & & \\
\hline $\mathrm{H} 2819$ & $\mathrm{H} 4633$ & Yes & $2 / 2 / 89$ & & & $\mathrm{X}$ (To TSD?) & \\
\hline $\mathrm{H} 4845$ & 89143 & No (Room) & $11 / 21 / 89$ & & & & $\mathrm{X}$ \\
\hline $\mathrm{H} 5000$ & 89413265 & Yes & $12 / 11 / 89$ & $\mathrm{X}$ & & & \\
\hline H5153 & H39080 & Yes & $10 / 26 / 89$ & X (To TSD?) & & & \\
\hline H5154 & H35100 & Yes & $9 / 12 / 89$ & X (To TSD?) & & & \\
\hline $\mathrm{H} 6723$ & AR278445 & Yes & $1 / 11 / 90$ & $\mathrm{X}$ & & & \\
\hline $\mathrm{H} 6734$ & 88610495 & Yes & $4 / 17 / 89$ & $\mathrm{X}$ & & & \\
\hline H6743 & $\mathrm{H} 4670$ & Yes & $4 / 6 / 89$ & X (To TSD?) & & & \\
\hline H6750 & H8963 & Yes & $3 / 10 / 89$ & $\mathrm{X}$ (To TSD?) & & & \\
\hline H9327 & 89413265 & Yes (612) & $12 / 11 / 89$ & & $\mathrm{X}$ & & \\
\hline H15971 & H35029 & No & $9 / 7 / 89$ & X (To TSD?) & & & \\
\hline $\mathrm{H} 17386$ & $\mathrm{H} 4635$ & Yes & $2 / 2 / 89$ & $\mathrm{X}$ (To TSD?) & & & \\
\hline
\end{tabular}



Table E-1. Spot checked H-requisition waste designation (cont'd).

\begin{tabular}{|c|c|c|c|c|c|c|c|}
\hline \multicolumn{8}{|c|}{ Spot-check Reqs } \\
\hline H-Req & Manifest & RMMA & Manifest Date & $\begin{array}{c}\text { Known } \\
\text { Radioactive }\end{array}$ & Clean Waste & $\begin{array}{c}\text { Likely } \\
\text { Radioactive }\end{array}$ & Likely Clean \\
\hline H19701 & S 514SRV-1 & Yes & $6 / 22 / 88$ & & $\mathrm{X}$ & & \\
\hline H19803 & S 514SRV-2 & Yes & $5 / 1 / 89$ & & $\bar{x}$ & & \\
\hline H19804 & 89413245 & Yes & $8 / 10 / 89$ & $x$ & & & \\
\hline H19805 & 89413242 & Yes & $8 / 8 / 89$ & $\mathrm{x}$ & & & \\
\hline H19807 & U H63635 & Yes & $12 / 26 / 88$ & $\mathrm{X}$ (To TSD?) & & & \\
\hline H19808 & 89413246 & Yes & $8 / 10 / 89$ & $\mathrm{x}$ & & & \\
\hline H19809 & 89413246 & Yes & $8 / 10 / 89$ & $\mathrm{x}$ & & & \\
\hline H19810 & 89413246 & Yes & $8 / 10 / 89$ & $\bar{x}$ & & & \\
\hline H19815 & 89413246 & $\overline{\text { Yes. }}$ & $8 / 10 / 89$ & $\bar{x}$ & & & \\
\hline H19811 & 89561609 & Yes & $2 / 13 / 90$ & $\bar{X}$ & & & \\
\hline H19812 & 89561609 & Yes & $2 / 13 / 90$ & $\bar{x}$ & & & \\
\hline H17385 & 89561609 & Yes & $2 / 13 / 90$ & $\bar{x}$ & & & \\
\hline H19813 & $\mathrm{H} 38365$ & Yes & $10 / 18 / 89$ & $\mathrm{X}$ (To TSD?) & & & \\
\hline H19814 & S 612SRV-4 & Yes & $12 / 23 / 88$ & $\mathrm{x}$ & & & \\
\hline H19816 & $\mathrm{H} 23062$ & Yes & $7 / 6 / 89$ & $\mathrm{X}$ (To TSD?) & & & \\
\hline H19821 & S 514SRV-1 & Yes & $7 / 6 / 89$ & & $\mathrm{x}$ & & \\
\hline H19893 & H23062 & Yes & $7 / 6 / 89$ & $\mathrm{X}$ (To TSD?) & & & \\
\hline $\mathrm{H} 22200$ & 91760064 & No & $3 / 11 / 92$ & & $\bar{x}$ & & \\
\hline $\mathrm{H} 23472$ & IL4128169 & Yes & $4 / 14 / 90$ & & & & $\bar{x}$ \\
\hline $\mathrm{H} 23473$ & IL4128169 & Yes & $4 / 14 / 90$ & & & & $\mathrm{x}$ \\
\hline $\mathrm{H} 23490$ & 89930389 & Yes & $4 / 13 / 90$ & & & & $\mathrm{X}$ \\
\hline H23518 & 89413375 & Yes (612) & $2 / 23 / 90$ & & & $\bar{x}$ & \\
\hline $\mathrm{H} 23470$ & 89930556 & No & $8 / 23 / 90$ & & $\mathrm{x}$ & & \\
\hline $\mathrm{H} 25705$ & $\mathrm{H} 57567$ & Yes & $3 / 28 / 90$ & & & & $\mathrm{x}$ \\
\hline $\mathrm{H} 25822$ & 89930393 & No & $6 / 6 / 90$ & & $\mathrm{X}$ & & \\
\hline H25998 & Not listed & No & Not listed & & $\bar{x}$ & & \\
\hline H26543 & 91760291 & No & $9 / 22 / 92$ & $\bar{x}$ & & & \\
\hline H27001 & AR395954 & Yes & $8 / 22 / 89$ & & & & $\mathrm{x}$ \\
\hline $\mathrm{H} 28411$ & 89930399 & Yes & $6 / 12 / 90$ & $\mathrm{x}$ & & & \\
\hline $\mathrm{H} 28412$ & 89930399 & Yes & $6 / 12 / 90$ & $\mathrm{x}$ & & & \\
\hline H28487 & R19733 & Yes & $7 / 12 / 89$ & & & $\mathrm{X}$ & \\
\hline H28489 & B91114 & Yes & $4 / 2 / 91$ & $\mathrm{X}$ (To TSD?) & & & \\
\hline $\mathrm{H} 28490$ & B91114 & Yes & $4 / 2 / 91$ & $\mathrm{X}$ (To TSD?) & & & \\
\hline $\begin{array}{l}\mathrm{H} 28605 \\
\mathrm{H} 20439 \\
\mathrm{H} 20440\end{array}$ & 89413326 & No & $8 / 29 / 89$ & $\bar{x}$ & & & \\
\hline $\mathrm{H} 28671$ & 89413326 & No & $8 / 29 / 89$ & $\mathrm{x}$ & & & \\
\hline $\mathrm{H} 28742$ & 90271782 & Yes & $1 / 2 / 91$ & $\mathrm{x}$ & & & \\
\hline $\mathrm{H} 28743$ & H54314 & Yes & $10 / 8 / 90$ & $\mathrm{X}$ (To TSD?) & & & \\
\hline H28749 & H54980 & Yes & $5 / 18 / 90$ & & & $\mathrm{x}$ & \\
\hline H30852 & 89930363 & Yes & $5 / 24 / 90$ & $\mathrm{X}$ & & & \\
\hline H30996 & Not listed & Yes & Not listed & $\mathrm{X}$ (To TSD?) & & & \\
\hline $\mathrm{H} 31202$ & 91760205 & Yes & $7 / 2 / 92$ & & $\bar{x}$ & & \\
\hline H31222 & 91760040 & Yes & $2 / 7 / 92$ & & & & $\mathrm{x}$ \\
\hline
\end{tabular}


Table E-2. Biased H-requisition waste designation.

\begin{tabular}{|c|c|c|c|c|c|c|}
\hline \multicolumn{7}{|c|}{ Biased Reqs } \\
\hline H-Req & Manifest & RMMA & $\begin{array}{c}\text { Known } \\
\text { Radioactive }\end{array}$ & Clean Waste & $\begin{array}{c}\text { Likely } \\
\text { Radioactive }\end{array}$ & $\begin{array}{r}\text { Likely } \\
\text { Clean }\end{array}$ \\
\hline H1907 & 89413280 & No & & & & $\mathrm{X}$ \\
\hline H1909 & 88610504 & Yes & & & & $\mathrm{X}$ \\
\hline $\mathrm{H} 1915$ & 87250917 & Yes & & & & $X$ \\
\hline H1916 & 87250928 & Yes & & & & $\mathrm{X}$ \\
\hline H1917 & 87250921 & Yes & & & & $\mathrm{X}$ \\
\hline H1918 & 87250646 & Yes & & & & $\bar{x}$ \\
\hline H14601 & 87250928 & Yes & & & & $\mathrm{X}$ \\
\hline $\mathrm{H} 14602-\mathrm{H} 14603$ & LA1152283 & Yes & & & & $X$ \\
\hline H14605 & LA1020677 & Yes & & & & $X$ \\
\hline H14629 & LA1020677 & Yes & & & & $X$ \\
\hline H14630 & LA1020677 & Yes & & & & $\mathrm{X}$ \\
\hline H14648 & 88461308 & Yes & & & & $\mathrm{X}$ \\
\hline H14649 & 89413244 & Yes & & & & $\mathrm{X}$ \\
\hline $\mathrm{H} 14656$ & 89413233 & Yes & & & & $\mathrm{X}$ \\
\hline H14659 & 89413233 & Yes & & & & $X$ \\
\hline $\mathrm{H} 14663$ & AR461929 & Yes & & & & $\mathrm{X}$ \\
\hline H14667 & 90271760 & Yes & & & & $\mathrm{X}$ \\
\hline $\mathrm{H} 26136$ & 90271902 & Yes & & & & $X$ \\
\hline H26139 & 90271967 & Yes & & & & $X$ \\
\hline $\mathrm{H} 26141-\mathrm{H} 26142$ & AR517595 & Yes & & & & $\mathrm{X}$ \\
\hline H26144-H26145 & 90271976 & Yes & & & & $x$ \\
\hline H26156-H26157 & 91760040 & Yes & & & & $\mathrm{X}$ \\
\hline $\mathrm{H} 26160$ & 90271968 & Yes & & & & $\mathrm{X}$ \\
\hline $\mathrm{H} 26162$ & 90271969 & Yes & & & & $\mathrm{X}$ \\
\hline H26166 & 91760025 & Yes & & & & $\mathrm{x}$ \\
\hline H26167 & AR517595 & Yes & & & & $\mathrm{X}$ \\
\hline H26168 & 90895389 & Yes & & & & $\mathrm{X}$ \\
\hline H26169 & $\begin{array}{l}90271913 \\
91760040 \\
\end{array}$ & Yes & & & & $X$ \\
\hline H26176 & 91760049 & Yes & & & & $\mathrm{x}$ \\
\hline H31552 & AR517587 & Yes & & & & $\mathrm{X}$ \\
\hline H31692 & $\begin{array}{l}90271913 \\
90271968 \\
90895372\end{array}$ & Yes & & & & $X$ \\
\hline H31719 & 89930556 & Yes & & & & $\mathrm{X}$ \\
\hline H61571-H61573 & 88411082 & Yes & & & & $\mathrm{X}$ \\
\hline H61901-H61904 & IL 3237944 & Yes & & & & $X$ \\
\hline H61964-H61987 & IL4128151 & Yes & & & & $\mathrm{X}$ \\
\hline H62140 & IL 4128248 & Yes & & & & $\mathrm{X}$ \\
\hline $\mathrm{H} 62147-62150$ & IL3237945 & Yes & & & & $\mathrm{X}$ \\
\hline H62189-62195 & IL3237942 & Yes & & & & $\mathrm{X}$ \\
\hline H62196-H62200 & IL3237944 & Yes & & & & $\mathrm{X}$ \\
\hline H62223-H62224 & IL4128151 & Yes & & & & $\mathrm{X}$ \\
\hline H62619-H62622 & 88655972 & Yes & & & & $\mathrm{X}$ \\
\hline H62714-H62729 & IL4128191 & Yes & & & & $X$ \\
\hline $\mathrm{H} 66701$ & 90895389 & Yes & & & & $\mathrm{X}$ \\
\hline H519 & 88610728 & Yes & & $\mathrm{X}$ & & \\
\hline
\end{tabular}


Table E-2. Biased H-requisition waste designation (cont'd).

\begin{tabular}{|c|c|c|c|c|c|c|}
\hline \multicolumn{7}{|c|}{ Biased Reqs } \\
\hline H-Req & Manifest & RMMA & $\begin{array}{c}\text { Known } \\
\text { Radioactive }\end{array}$ & Clean Waste & $\begin{array}{c}\text { Likely } \\
\text { Radioactive }\end{array}$ & $\begin{array}{l}\text { Likely } \\
\text { Clean }\end{array}$ \\
\hline H6901 & 87250898 & Yes & & $\bar{x}$ & & \\
\hline H6902 & $\begin{array}{l}87250872 \\
87250891\end{array}$ & Yes & & $\bar{x}$ & & \\
\hline $\mathrm{H} 6904$ & 87250900 & Yes & & $\bar{x}$ & & \\
\hline H6906 & 87250876 & Yes & & $\mathrm{x}$ & & \\
\hline H6951-H6953 & 89413211 & Yes & & $\bar{x}$ & & \\
\hline H6955 & 87250960 & Yes & & $\bar{x}$ & & \\
\hline H6956 & 89413247 & Yes & & $\mathrm{X}$ & & \\
\hline H6966 & 89413247 & Yes & & $x$ & & \\
\hline H6969-H6970 & L89088 & Yes & & $\bar{x}$ & & \\
\hline H6973-H6974 & 89413247 & Yes & & $x$ & & \\
\hline $\mathrm{H} 8844$ & 88461313 & Yes & & $\bar{x}$ & & \\
\hline H19783-H19784 & 87250960 & Yes & & & $\mathrm{x}$ & \\
\hline $\mathrm{H} 22103$ & 90271810 & $\overline{Y e s}$ & & $\bar{x}$ & & \\
\hline $\mathrm{H} 22110$ & 89930464 & Yes & & $\bar{x}$ & & \\
\hline H22111 & 90271810 & Yes & & $\bar{x}$ & & \\
\hline H22114 & 90271810 & Yes & & $\bar{x}$ & & \\
\hline $\mathrm{H} 22125$ & 90271944 & Yes & & $\bar{x}$ & & \\
\hline $\mathrm{H} 22130$ & 90895339 & Yes & & $\bar{x}$ & & \\
\hline $\mathrm{H} 22131$ & 91760025 & $\overline{Y e s}$ & & $\bar{x}$ & & \\
\hline $\mathrm{H} 22132$ & 90895339 & Yes & & $\bar{x}$ & & \\
\hline $\mathrm{H} 22150$ & 90895329 & Yes & & $\mathrm{x}$ & & \\
\hline H22163 & 90271935 & Yes & & $\bar{x}$ & & \\
\hline $\mathrm{H} 22165-\mathrm{H} 22166$ & 90895339 & Yes & & $\bar{x}$ & & \\
\hline $\mathrm{H} 22168$ & 90895303 & Yes & & $\mathrm{x}$ & & \\
\hline H22169-H22171 & 90895372 & Yes & & $\mathrm{x}$ & & \\
\hline $\mathrm{H} 22203$ & 90895303 & Yes & & $\mathrm{X}$ & & \\
\hline $\mathrm{H} 22204-\mathrm{H} 22205$ & 90895355 & Yes & & $\mathrm{x}$ & & \\
\hline $\mathrm{H} 22207$ & 90895372 & Yes & & $\mathrm{x}$ & & \\
\hline $\mathrm{H} 22222$ & 90271810 & Yes & & $\bar{x}$ & & \\
\hline $\mathrm{H} 22223$ & 90271935 & Yes & & $\mathrm{X}$ & & \\
\hline $\mathrm{H} 22224$ & 90271810 & Yes & & $\bar{x}$ & & \\
\hline $\mathrm{H} 23423-\mathrm{H} 23424$ & 89930389 & Yes & & & $\bar{x}$ & \\
\hline $\mathrm{H} 23454$ & 89930354 & Yes & & $\bar{x}$ & & \\
\hline $\mathrm{H} 19004$ & 87250672 & Yes & & & & $\mathrm{x}$ \\
\hline H13927-H13928 & 87250960 & Yes & & & & $\mathrm{x}$ \\
\hline H13941 & 88610504 & Yes & & & & $\bar{x}$ \\
\hline H13967 & 87250646 & Yes & & & & $\mathrm{X}$ \\
\hline H44447-H44448 & 89930488 & Yes & & $\mathrm{X}$ & & \\
\hline H44481-H44482 & 89930309 & $\overline{\text { Yes }}$ & $\bar{x}$ & & & \\
\hline $\mathrm{H} 46125$ & 97091 & Yes & & $\mathrm{x}$ & & \\
\hline H46132 & 91760186 & Yes & & $\bar{x}$ & & \\
\hline $\mathrm{H} 46133$ & 91760222 & Yes & & $\mathrm{X}$ & & \\
\hline H46144 & Not Listed & Yes & & $\overline{\mathrm{X}}$ & & \\
\hline $\mathrm{H} 6702$ & 87250904 & Yes & & & & $\mathrm{X}$ \\
\hline
\end{tabular}


Table E-2. Biased H-requisition waste designation (cont'd).

\begin{tabular}{|c|c|c|c|c|c|c|}
\hline \multicolumn{7}{|c|}{ Biased Reqs } \\
\hline H-Req & Manifest & RMMA & $\begin{array}{c}\text { Known } \\
\text { Radioactive }\end{array}$ & Clean Waste & $\begin{array}{c}\text { Likely } \\
\text { Radioactive }\end{array}$ & $\begin{array}{r}\text { Likely } \\
\text { Clean }\end{array}$ \\
\hline H6705 & 87250879 & Yes & & & & $\bar{x}$ \\
\hline H6706 & 87250869 & Yes & & & & $\mathrm{X}$ \\
\hline H6709 & 87250963 & Yes & & & & $x$ \\
\hline H6714 & 87250876 & Yes & & & & $\mathrm{X}$ \\
\hline H6718 & 89413222 & Yes & & & & $\bar{x}$ \\
\hline H6732 & 872507895 & Yes & & & & $\bar{x}$ \\
\hline $\mathrm{H} 6735$ & $\begin{array}{l}87250943 \\
87250962\end{array}$ & Yes & & & & $\bar{X}$ \\
\hline H6736 & 87250940 & Yes & & & & $\bar{x}$ \\
\hline H6737 & 87250917 & Yes & & & & $\bar{x}$ \\
\hline H6739 & 87250928 & Yes & & & & $\mathrm{X}$ \\
\hline H6744 & L-89087 & Yes & & & & $X$ \\
\hline H6748 & 87250963 & Yes & & & & $x$ \\
\hline H6751 & $\begin{array}{l}88461298 \\
88610922\end{array}$ & Yes & & & & $\bar{x}$ \\
\hline H6799 & $\begin{array}{l}87250956 \\
87250962\end{array}$ & Yes & & & & $\mathrm{X}$ \\
\hline $\mathrm{H} 7002$ & $\begin{array}{l}87250951 \\
87250962\end{array}$ & Yes & & & $\bar{x}$ & \\
\hline $\mathrm{H} 7003$ & $\begin{array}{l}87250951 \\
87250962\end{array}$ & Yes & 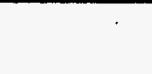 & & & $\bar{X}$ \\
\hline $\mathrm{H} 7004$ & $\begin{array}{l}87250956 \\
87250962\end{array}$ & Yes & & & & $\bar{X}$ \\
\hline H10430 & $\begin{array}{l}89413242 \\
89413244\end{array}$ & Yes & & & & $\mathrm{X}$ \\
\hline H10449 & 88461298 & Yes & & & $\mathrm{X}$ & $\mathrm{X}$ \\
\hline H19610 & 87250868 & No & & $\mathrm{X}$ & & \\
\hline H26201 & AR517588 & Yes & & & & $\mathrm{x}$ \\
\hline H26790 & 89930321 & Yes & & & & $X$ \\
\hline $\mathrm{H} 26824$ & 89930556 & Yes & & & & $\mathrm{X}$ \\
\hline $\mathrm{H} 44418$ & 90271952 & yes & & & & $\mathrm{X}$ \\
\hline H46126 & $\begin{array}{l}92258817 \\
92258846\end{array}$ & Yes & & & & $\bar{x}$ \\
\hline $\mathrm{H} 46135$ & 91760205 & No & & $\mathrm{X}$ & & $\mathrm{X}$ \\
\hline $\mathrm{H} 46145$ & 90895351 & No & & $\mathrm{X}$ & & $\mathrm{X}$ \\
\hline H46156 & 91760147 & Yes & & & & $\mathrm{X}$ \\
\hline $\mathrm{H} 46157$ & 91760213 & Yes & & & & $x$ \\
\hline $\mathrm{H} 46158$ & 90271975 & Yes & & & & $\mathrm{x}$ \\
\hline H46159 & 90895367 & Yes & & & & $\mathrm{X}$ \\
\hline $\mathrm{H} 46160$ & 91760068 & Yes & & & & $\bar{X}$ \\
\hline H39391 & 89930543 & Yes & & & & $\mathrm{X}$ \\
\hline H39395-H39410 & 89413382 & Yes & & & & $\mathrm{X}$ \\
\hline H23457 & $\begin{array}{l}89930389 \\
89930495\end{array}$ & Yes & & & & $\mathrm{X}$ \\
\hline $\mathrm{H} 23862-\mathrm{H} 23865$ & 89930495 & Yes & & & & $X$ \\
\hline H23867-H23869 & 89930495 & Yes & & & & $\bar{X}$ \\
\hline H33937 & AR269314 & $\overline{\text { Yes }}$ & & & & $\bar{x}$ \\
\hline H33979 & 90271898 & Yes & & & & $\mathrm{X}$ \\
\hline
\end{tabular}


Table E-2. Biased H-requisition waste designation (cont'd).

\begin{tabular}{|c|c|c|c|c|c|c|}
\hline \multicolumn{7}{|c|}{ Biased Reqs } \\
\hline H-Req & Manifest & RMMA & $\begin{array}{c}\text { Known } \\
\text { Radioactive }\end{array}$ & Clean Waste & $\begin{array}{c}\text { Likely } \\
\text { Radioactive }\end{array}$ & $\begin{array}{l}\text { Likely } \\
\text { Clean }\end{array}$ \\
\hline H44968 & AR485808 & $\overline{Y e s}$ & & & & $\mathrm{X}$ \\
\hline H44969 & AR461930 & Yes & & & & $\mathrm{x}$ \\
\hline H44970 & 90271772 & Yes & & & & $\overline{\mathrm{X}}$ \\
\hline H44971 & AR485422 & Yes & & & & $\mathrm{x}$ \\
\hline $\mathrm{H} 44972$ & 89986276 & Yes & & & & $\bar{x}$ \\
\hline H44974 & 223157 & Yes & & & & $\mathrm{x}$ \\
\hline H44975 & AR461930 & Yes & & & & $\mathrm{x}$ \\
\hline H44976 & AR485808 & Yes & & & & $\mathrm{x}$ \\
\hline H44977-H44978 & AR461930 & Yes & & & & $\mathrm{X}$ \\
\hline $\mathrm{H} 46476$ & 91760128 & No & & $\bar{x}$ & & \\
\hline H55676 & 89930389 & Yes & & & & $\mathrm{x}$ \\
\hline H55677 & 89930440 & Yes & & & & $\mathrm{x}$ \\
\hline H55691 & 89930354 & Yes & & & & $\mathrm{X}$ \\
\hline H55692 & 89930440 & Yes & & & & $\bar{x}$ \\
\hline H55693 & 89930389 & Yes & & & & $\bar{x}$ \\
\hline H55695 & 89930354 & Yes & & & & $\mathrm{X}$ \\
\hline H55696-H55698 & 89930389 & $\overline{Y e s}$ & & & & $\bar{x}$ \\
\hline H55700 & 89930468 & Yes & & & & $\bar{x}$ \\
\hline H64001 & 90895372 & No & & & $\bar{x}$ & \\
\hline H71467 & 9170244 & No & & & $\bar{x}$ & \\
\hline H72407-H72408 & 91760025 & No & & & $\bar{x}$ & \\
\hline H559 & 87250967 & No & & & $\mathrm{x}$ & \\
\hline $\mathrm{H} 513$ & 87250951 & No & & & $\mathrm{x}$ & \\
\hline H2333-H2334 & 89413252 & No & & & $\mathrm{x}$ & \\
\hline H4113 & $\begin{array}{l}87250933 \\
87250950 \\
\end{array}$ & No & & & $\bar{x}$ & \\
\hline H6623 & 89413280 & No & & & $\bar{x}$ & \\
\hline H6628 & 89413233 & No & & & $\mathrm{x}$ & \\
\hline H6633 & 89413233 & No & & & $\mathrm{x}$ & \\
\hline H6637 & 89413241 & No & & & $\bar{x}$ & \\
\hline $\mathrm{H} 6640$ & 89413244 & No & & & $x$ & \\
\hline H6641-H6642 & 89413227 & No & & & $\mathrm{x}$ & \\
\hline H6676 & 89413241 & No & & & $\mathrm{x}$ & \\
\hline $\mathrm{H} 6678$ & 89413293 & No & & & $\mathrm{x}$ & \\
\hline $\mathrm{H} 6700$ & 89413241 & No & & & $\mathrm{x}$ & \\
\hline H7001 & $\begin{array}{l}87250951 \\
87250962\end{array}$ & No & & & $\mathrm{x}$ & \\
\hline H7005 & $\begin{array}{l}87250956 \\
87250962\end{array}$ & No & & & $\mathrm{x}$ & \\
\hline H7006 & $\begin{array}{l}87250956 \\
87250962\end{array}$ & No & & & $\bar{x}$ & \\
\hline H7007 & $\begin{array}{l}87250956 \\
87250962 \\
\end{array}$ & No & & & $\bar{x}$ & \\
\hline H7008 & $\begin{array}{l}87250956 \\
87250962 \\
\end{array}$ & No & & & $\bar{x}$ & \\
\hline H7009 & $\begin{array}{l}87250956 \\
87250962\end{array}$ & No & & & $\bar{x}$ & \\
\hline
\end{tabular}


Table E-2. Biased H-requisition waste designation (cont'd).

\begin{tabular}{|c|c|c|c|c|c|c|}
\hline \multicolumn{7}{|c|}{ Biased Reqs } \\
\hline H-Req & Manifest & RMMA & $\begin{array}{c}\text { Known } \\
\text { Radioactive }\end{array}$ & Clean Waste & $\begin{array}{c}\text { Likely } \\
\text { Radioactive }\end{array}$ & $\begin{array}{l}\text { Likely } \\
\text { Clean }\end{array}$ \\
\hline $\mathrm{H} 7010$ & 87250956 & No & & & $\mathrm{X}$ & \\
\hline H7011 & 87250939 & No & & & $\mathrm{X}$ & \\
\hline H7012 & $\begin{array}{l}87250956 \\
87250962\end{array}$ & No & & & $\bar{x}$ & \\
\hline $\mathrm{H} 7013$ & $\begin{array}{l}87250956 \\
87250962\end{array}$ & No & & & $\mathrm{x}$ & \\
\hline H7014 & $\begin{array}{l}87250956 \\
87250962\end{array}$ & No & & & $\mathrm{X}$ & \\
\hline H7015 & $\begin{array}{l}87250956 \\
87250962\end{array}$ & No & & $X$ & & \\
\hline H7016 & $\begin{array}{l}87250956 \\
87250962\end{array}$ & No & & $\bar{X}$ & & \\
\hline H7017 & $\begin{array}{l}87250956 \\
87250962\end{array}$ & No & & $\mathrm{X}$ & & \\
\hline H7018-H7023 & 87250960 & No & & $\mathrm{X}$ & & \\
\hline H7024 & $\begin{array}{l}87250956 \\
87250962\end{array}$ & No & & $\mathrm{X}$ & & \\
\hline $\mathrm{H} 7025$ & $\begin{array}{l}87250956 \\
87250962\end{array}$ & No & & $\bar{x}$ & . & \\
\hline $\mathrm{H} 7026$ & $\begin{array}{l}87250956 \\
87250962\end{array}$ & No & & $\mathrm{X}$ & & \\
\hline H7027 & $\begin{array}{l}87250956 \\
87250962 \\
\end{array}$ & No & & $\mathrm{X}$ & & \\
\hline $\mathrm{H} 7028$ & $\begin{array}{l}87250956 \\
87250962\end{array}$ & No & & $\mathrm{X}$ & & \\
\hline H7029 & $\begin{array}{l}87250956 \\
87250962\end{array}$ & No & & $\mathrm{X}$ & & \\
\hline H7030 & $\begin{array}{l}87250956 \\
87250962\end{array}$ & No & & $\bar{x}$ & & \\
\hline H7031 & $\begin{array}{l}87250956 \\
87250962\end{array}$ & No & & $\mathrm{X}$ & & \\
\hline H7032 & $\begin{array}{l}87250956 \\
87250962\end{array}$ & No & & $\bar{X}$ & & \\
\hline H7033 & $\begin{array}{l}87250956 \\
87250962\end{array}$ & No & & $\bar{x}$ & & \\
\hline H7034 & $\begin{array}{l}87250956 \\
87250962\end{array}$ & No & & $\bar{X}$ & & \\
\hline $\mathrm{H} 7035$ & $\begin{array}{l}87250956 \\
87250962\end{array}$ & No & & $x$ & & \\
\hline H7036 & $\begin{array}{l}87250956 \\
87250962\end{array}$ & No & & $X$ & & \\
\hline $\mathrm{H} 7037$ & $\begin{array}{l}87250956 \\
87250962\end{array}$ & No & & $x$ & & \\
\hline H7038 & $\begin{array}{l}87250956 \\
87250962\end{array}$ & No & & $\mathrm{X}$ & & \\
\hline H7039 & $\begin{array}{l}87250956 \\
87250962\end{array}$ & No & & $\bar{X}$ & & \\
\hline $\mathrm{H} 7040$ & $\begin{array}{l}87250956 \\
87250962\end{array}$ & No & & $\mathrm{X}$ & & \\
\hline H7041 & $\begin{array}{l}87250956 \\
87250962\end{array}$ & No & & $\mathrm{X}$ & & \\
\hline H7042 & $\begin{array}{l}87250956 \\
87250962\end{array}$ & No & & $\bar{X}$ & & \\
\hline
\end{tabular}


Table E-2. Biased H-requisition waste designation (cont'd).

\begin{tabular}{|c|c|c|c|c|c|c|}
\hline \multicolumn{7}{|c|}{ Biased Reqs } \\
\hline $\begin{array}{l}\text { H-Req } \\
\text { H7044 }\end{array}$ & $\begin{array}{l}\text { Manifest } \\
\mathbf{8 7 2 5 0 9 5 6} \\
\mathbf{8 7 2 5 0 9 6 2}\end{array}$ & $\begin{array}{l}\text { RMMA } \\
\text { No }\end{array}$ & $\begin{array}{c}\text { Known } \\
\text { Radioactive }\end{array}$ & $\begin{array}{c}\text { Clean Waste } \\
\mathrm{X}\end{array}$ & $\begin{array}{c}\text { Likely } \\
\text { Radioactive }\end{array}$ & $\begin{array}{l}\text { Likely } \\
\text { Clean }\end{array}$ \\
\hline H7045 & $\begin{array}{l}87250956 \\
87250962\end{array}$ & No & & $\mathrm{x}$ & & \\
\hline H7046 & $\begin{array}{l}87250956 \\
87250962\end{array}$ & No & & $\bar{x}$ & & \\
\hline $\mathrm{H} 7047$ & $\begin{array}{l}87250956 \\
87250962\end{array}$ & No & & $\mathrm{x}$ & & \\
\hline H7048 & $\begin{array}{l}87250956 \\
87250962\end{array}$ & No & & $\bar{x}$ & & \\
\hline H7049 & $\begin{array}{l}87250956 \\
87250962\end{array}$ & No & & $\mathrm{x}$ & & \\
\hline $\mathrm{H7050}$ & $\begin{array}{l}87250956 \\
87250962\end{array}$ & No & & $\bar{x}$ & & \\
\hline H7051 & $\begin{array}{l}87250956 \\
87250962\end{array}$ & No & & $\mathrm{x}$ & & \\
\hline H7052 & $\begin{array}{l}87250956 \\
87250962\end{array}$ & No & & $\mathrm{x}$ & & \\
\hline H7053 & $\begin{array}{l}87250956 \\
87250962 \\
\end{array}$ & No & & $\mathrm{x}$ & & \\
\hline H7055 & $\begin{array}{l}88461299 \\
88601502\end{array}$ & No & & $\mathrm{x}$ & & \\
\hline H7056 & $\begin{array}{l}88461299 \\
88601502\end{array}$ & No & & $\mathrm{x}$ & & \\
\hline H7057 & $\begin{array}{l}88461299 \\
88601502\end{array}$ & No & & $\mathrm{x}$ & & \\
\hline H7058 & $\begin{array}{l}88461299 \\
88601502\end{array}$ & No & & $\bar{x}$ & & \\
\hline H7059 & $\begin{array}{l}88461299 \\
88601502\end{array}$ & No & & $\mathrm{x}$ & & \\
\hline $\mathrm{H} 7060$ & $\begin{array}{l}88461299 \\
88601502\end{array}$ & No & & $\mathrm{x}$ & & \\
\hline H7062 & $\begin{array}{l}88461299 \\
88601502 \\
\end{array}$ & No & & $\bar{x}$ & & \\
\hline H7063 & $\begin{array}{l}88461298 \\
88601501\end{array}$ & No & & $\mathrm{x}$ & & \\
\hline H7064 & $\begin{array}{l}88461298 \\
88601501\end{array}$ & No & & $\bar{x}$ & & \\
\hline H7065 & $\begin{array}{l}88461298 \\
88601502 \\
\end{array}$ & No & & $\mathrm{x}$ & & \\
\hline H7066 & $\begin{array}{l}88461298 \\
88601502\end{array}$ & No & & $\mathrm{x}$ & & \\
\hline H7067-H7074 & 89413293 & No & & $\mathrm{x}$ & & \\
\hline H7075 & $\begin{array}{l}89413280 \\
89413293\end{array}$ & No & & $\mathrm{x}$ & & \\
\hline H7076-7089 & 89413293 & No & & $\mathrm{x}$ & & \\
\hline H7090-7094 & 89413265 & No & & $\mathrm{x}$ & & \\
\hline $\mathrm{H} 8880$ & 88461308 & No & & $\mathrm{x}$ & & \\
\hline H13113 & 88413252 & No & & $\mathrm{x}$ & & \\
\hline H13135 & 88413252 & No & & $\mathrm{x}$ & & \\
\hline H13152-H13157 & 87250899 & No & & $\mathrm{X}$ & & \\
\hline H13158 & 87250939 & No & & $\mathrm{x}$ & & \\
\hline
\end{tabular}


Table E-2. Biased H-requisition waste designation (cont'd).

\begin{tabular}{|c|c|c|c|c|c|c|}
\hline \multicolumn{7}{|c|}{ Biased Reqs } \\
\hline H-Req & Manifest & RMMA & $\begin{array}{c}\text { Known } \\
\text { Radioactive }\end{array}$ & Clean Waste & $\begin{array}{c}\text { Likely } \\
\text { Radioactive }\end{array}$ & $\begin{array}{l}\text { Likely } \\
\text { Clean }\end{array}$ \\
\hline H13159-H13160 & 87250899 & No & & $\bar{x}$ & & \\
\hline H13164-13178 & $\begin{array}{l}87250885 \\
87250890\end{array}$ & No & & $\bar{x}$ & & \\
\hline H13182-13186 & $\begin{array}{l}87250885 \\
87250890\end{array}$ & No & & $\bar{x}$ & & \\
\hline H13188 & $\begin{array}{l}87250885 \\
87250890\end{array}$ & No & & $\bar{x}$ & & \\
\hline H13189-H13190 & 87250960 & No & & $\mathrm{X}$ & & \\
\hline H13191-13199 & $\begin{array}{l}87250885 \\
87250890\end{array}$ & No & & $\mathrm{X}$ & & \\
\hline H13201-13225 & 87250921 & No & & $\mathrm{X}$ & & \\
\hline H13241-H13243 & $\begin{array}{l}87250956 \\
87250962\end{array}$ & No & & $\bar{x}$ & & \\
\hline H13244 & $\begin{array}{l}87250672 \\
88535038\end{array}$ & No & & $\mathrm{x}$ & & \\
\hline H13245 & 88610723 & No & & $\mathrm{x}$ & & \\
\hline H13253-H13254 & 89413211 & No & & $\mathrm{x}$ & & \\
\hline H13256 & 89413286 & No & & $\mathrm{x}$ & & \\
\hline $\mathrm{H} 13260$ & 89413233 & No & & $\mathrm{X}$ & & \\
\hline H13276 & $\begin{array}{l}87250672 \\
88535038\end{array}$ & No & & $\bar{x}$ & & \\
\hline H13278-H13280 & $\begin{array}{l}88461298 \\
88601501 \\
\end{array}$ & No & & $\mathrm{x}$ & & \\
\hline H13294-H13299 & 88610503 & No & & $\bar{x}$ & & \\
\hline $\mathrm{H} 69490$ & 91760126 & Yes & & $\mathrm{x}$ & & \\
\hline H6911-H69612 & 89413256 & Yes & & & & $\bar{x}$ \\
\hline H6924 & 89930218 & Yes & & & & $\mathrm{x}$ \\
\hline H6927 & 89413284 & Yes & & & & $\mathrm{x}$ \\
\hline H6934-H6938 & 89413286 & Yes & & & & $\mathrm{X}$ \\
\hline H6940-6945 & 89413286 & Yes & & & & $\mathrm{x}$ \\
\hline H6950 & 88610495 & Yes & & & & $\bar{x}$ \\
\hline $\mathrm{H} 9723$ & 89413344 & Yes & & & & $\mathrm{x}$ \\
\hline H17309-H17312 & 87250898 & Yes & & & & $\mathrm{x}$ \\
\hline H17312 & 87250927 & Yes & & & & $\mathrm{x}$ \\
\hline H17316 & 87250927 & Yes & & & & $\mathrm{x}$ \\
\hline H19670 & 87250927 & Yes & & & & $\mathrm{x}$ \\
\hline H19785 & 89413252 & Yes & & & & $\mathrm{x}$ \\
\hline H19789-H19791 & 89413252 & Yes & & & & $\mathrm{X}$ \\
\hline H19806 & 87250956 & Yes & & & & $\bar{x}$ \\
\hline H19820 & 885345038 & Yes & & & & $\mathrm{x}$ \\
\hline H19823-H19826 & 89413286 & Yes & & & & $\mathrm{x}$ \\
\hline $\mathrm{H} 19827$ & 89413222 & Yes & & & & $x$ \\
\hline H19828 & 89413286 & Yes & & & & $\bar{x}$ \\
\hline H19830-H19831 & 89930218 & Yes & & & & $\mathrm{X}$ \\
\hline H19833 & 88610495 & Yes & & & & $\mathrm{x}$ \\
\hline H19835 & 87250957 & Yes & & & & $\mathrm{X}$ \\
\hline H19891 & 88461302 & Yes & & & & $\mathrm{x}$ \\
\hline
\end{tabular}


Table E-2. Biased H-requisition waste designation (cont'd).

\begin{tabular}{|c|c|c|c|c|c|c|}
\hline \multicolumn{7}{|c|}{ Biased Reqs } \\
\hline H-Req & Manifest & RMMA & $\begin{array}{c}\text { Known } \\
\text { Radioactive }\end{array}$ & Clean Waste & $\begin{array}{c}\text { Likely } \\
\text { Radioactive }\end{array}$ & $\begin{array}{l}\text { Likely } \\
\text { Clean }\end{array}$ \\
\hline H19895 & 89413244 & Yes & & & & $\mathrm{X}$ \\
\hline H19900 & 88461313 & Yes & & & & $\mathrm{x}$ \\
\hline H19956 & 87250927 & Yes & & & $\mathrm{X}$ & \\
\hline H22730 & 89930218 & Yes & & & & $\bar{x}$ \\
\hline H22756 & 89930279 & Yes & & & & $\mathrm{x}$ \\
\hline $\mathrm{H} 28402-\mathrm{H} 28403$ & 89930218 & Yes & & & & $\mathrm{X}$ \\
\hline H28406-H28409 & 89930586 & Yes & & & & $\mathrm{x}$ \\
\hline $\mathrm{H} 28414-428415$ & 89930586 & Yes & & & & $\bar{x}$ \\
\hline H28421 & 89930543 & Yes & & & & $\mathrm{X}$ \\
\hline $\mathrm{H} 28422$ & 89930586 & Yes & & & & $\bar{x}$ \\
\hline $\mathrm{H} 28424$ & 89930543 & Yes & & & & $\bar{x}$ \\
\hline $\mathrm{H} 28426$ & 89930581 & Yes & & & & $\bar{x}$ \\
\hline $\mathrm{H} 28427$ & 89930586 & Yes & & & & $\bar{X}$ \\
\hline $\mathrm{H} 28428$ & 89930581 & Yes & & & & $\bar{X}$ \\
\hline $\mathrm{H} 28432$ & 89930581 & Yes & & & & $\mathrm{x}$ \\
\hline H28434 & 90895294 & Yes & & & & $\mathrm{x}$ \\
\hline $\mathrm{H} 28435$ & 90271904 & Yes & & & & $\mathrm{x}$ \\
\hline $\mathrm{H} 28460$ & 90895359 & Yes & & & & $\bar{x}$ \\
\hline $\mathrm{H} 28461$ & 90271904 . & Yes & & & & $\mathrm{x}$ \\
\hline $\mathrm{H} 28462$ & 90895369 & Yes & & & & $\bar{x}$ \\
\hline $\mathrm{H} 28463$ & 90271755 & Yes & & & & $\bar{x}$ \\
\hline $\mathrm{H} 28464-\mathrm{H} 28465$ & 90271754 & Yes & & & & $\mathrm{x}$ \\
\hline $\mathrm{H} 28466$ & 90271904 & Yes & & & & $\bar{x}$ \\
\hline $\mathrm{H} 28467-\mathrm{H} 28468$ & 90895369 & Yes & & $\mathrm{x}$ & & \\
\hline $\mathrm{H} 28482$ & 90271868 & Yes & & $\mathrm{x}$ & & \\
\hline $\mathrm{H} 28483$ & 90895369 & Yes & & $\mathrm{x}$ & & \\
\hline H28485 & 90895369 & Yes & & & & $\mathrm{x}$ \\
\hline $\mathrm{H} 28486$ & 90271940 & Yes & & & & $\mathrm{x}$ \\
\hline H28491-H28492 & 9071940 & Yes & & & & $\bar{x}$ \\
\hline H28493-H28497 & 90271967 & Yes & & & & $\mathrm{X}$ \\
\hline $\mathrm{H} 28500$ & 89930218 & Yes & & & & $x$ \\
\hline $\mathrm{H} 28523$ & 89930218 & Yes & & & & $\mathrm{x}$ \\
\hline $\mathrm{H} 28553$ & 90895369 & Yes & & & & $\mathrm{x}$ \\
\hline H28554 & 90271961 & Yes & & & & $\mathrm{x}$ \\
\hline H28555-H28556 & 90271967 & Yes & & & & $\bar{x}$ \\
\hline H44967 & AR485808 & Yes & & $\bar{x}$ & & \\
\hline $\mathrm{H} 44973$ & AR461930 & Yes & & $\bar{x}$ & & \\
\hline H69402 & $\begin{array}{l}90271969 \\
90271975 \\
\end{array}$ & Yes & & & & \\
\hline H69403 & 91760147 & Yes & & & & \\
\hline H69409 & 91760209 & Yes & & & & \\
\hline $\mathrm{H} 69410$ & 91760147 & Yes & & & & \\
\hline H69413-H69414 & 91760147 & Yes & & $\mathrm{x}$ & & \\
\hline $\mathrm{H} 69415$ & 91760199 & Yes & & $\bar{x}$ & & \\
\hline $\mathrm{H} 69416$ & 91760110 & Yes & & $\mathrm{X}$ & & \\
\hline
\end{tabular}


Table E-2. Biased H-requisition waste designation (cont'd).

\begin{tabular}{|c|c|c|c|c|c|c|}
\hline \multicolumn{7}{|c|}{ Biased Reqs } \\
\hline H-Req & Manifest & RMMA & $\begin{array}{c}\text { Known } \\
\text { Radioactive }\end{array}$ & Clean Waste & $\begin{array}{c}\text { Likely } \\
\text { Radioactive }\end{array}$ & $\begin{array}{l}\text { Likely } \\
\text { Clean }\end{array}$ \\
\hline H69417 & AR557561 & Yes & & $\mathrm{X}$ & & \\
\hline H69478 & 90895275 & $\overline{\text { Yes }}$ & & $\bar{X}$ & & \\
\hline H69479 & 90895369 & $\overline{\text { Yes }}$ & & $\bar{x}$ & & \\
\hline H69480 & 91760147 & Yes & & $\bar{X}$ & & \\
\hline H69481 & 90895351 & Yes & & $\mathrm{X}$ & & \\
\hline H69482-H69483 & AR517587 & Yes & & $\bar{X}$ & & \\
\hline H69484 & 91760110 & Yes & & $\mathrm{X}$ & & \\
\hline H69485-H69486 & 91760171 & Yes & & $\bar{X}$ & & \\
\hline H69487 & 91760110 & Yes & & $\bar{X}$ & & \\
\hline H69488 & 91760244 & Yes & & & & $\bar{X}$ \\
\hline H69488 & $\begin{array}{l}\text { AR517584 } \\
\text { AR517587 }\end{array}$ & Yes & & & & $\bar{X}$ \\
\hline H4634-H4651 & 89561609 & Yes (612) & $\mathrm{X}$ & & & \\
\hline H8964 & 89561609 & Yes (612) & & & & $\bar{X}$ \\
\hline H23054-H23057 & 89561609 & Yes (612) & & & & $\mathrm{X}$ \\
\hline $\mathrm{H} 23065-\mathrm{H} 23068$ & 89561609 & Yes $(612)$ & & & & $\mathrm{X}$ \\
\hline $\mathrm{H} 23073$ & 89561609 & Yes (612) & & & & $\bar{X}$ \\
\hline H23514-H23516 & 89561609 & Yes (612) & & & & $\mathrm{X}$ \\
\hline$\overline{\mathrm{H} 58408}$ & 89561609 & Yes (612) & & & & $\mathrm{X}$ \\
\hline H58411 & 89561609 & Yes (612) & & & & $\mathrm{X}$ \\
\hline H58415-H58419 & 89561609 & Yes (612) & & & & $\bar{X}$ \\
\hline H58422 & 89561609 & Yes (612) & & & & $\bar{x}$ \\
\hline H58450 & 89561609 & Yes (612) & & & & $\mathrm{X}$ \\
\hline H58455 & 89561609 & Yes (612) & & & & $\bar{X}$ \\
\hline H58458 & 89561609 & Yes (612) & & & & $\bar{x}$ \\
\hline H58476-H58477 & 89561609 & Yes (612) & & & & $\bar{x}$ \\
\hline
\end{tabular}

